UNIVERSIDADE DE SÃO PAULO

Programa Interunidades em Ensino de Ciências

Modalidade Química

\title{
As demonstrações e experimentos químicos no Chemical Catechism de Samuel Parkes (1761-1825)
}

Versão Corrigida

Dissertação de mestrado apresentada ao Instituto de Física, ao Instituto de Química, ao Instituto de Biociências e à Faculdade de Educação da Universidade de São Paulo, para a obtenção do título de Mestre em Ensino de Ciências.

Raissa Martins Idalgo e Silva

Orientador: Prof. Dr. Paulo Alves Porto 


\section{FICHA CATALOGRÁFICA \\ Preparada pelo Serviço de Biblioteca e Informação do Instituto de Física da Universidade de São Paulo}

Silva, Raissa Martins Idalgo e

As demonstrações e experimentos químicos no Chemical Catechism de Samuel Parkes (1761-1825). São Paulo, 2019.

Dissertação (Mestrado) - Universidade de São Paulo. Faculdade de Educação, Instituto de Física, Instituto de Química e Instituto de Biociências.

Orientador: Prof. Dr. Paulo Alves Porto

Área de Concentração: Ensino de Ciências.

Unitermos: 1. Química - Estudo e ensino; 2. Divulgação científica; 3. História da ciência; 4. Experimentos científicos. 


\section{Agradecimentos}

Aos meus pais, Cláudia e Marcelo, ao meu irmão Renan e meus avós, Joice e Jorge, por todo apoio e compreensão durante toda uma vida. Agradeço também à família que não é de sangue, mas de coração, os amigos que muito me apoiaram nessa jornada: Yasmin, Íris, Felipe, Adriano, Carla e Gabrielle.

Ao Professor Paulo Alves Porto, por toda sua paciência e orientação nesses anos de pesquisa, e pelos conselhos que muito contribuíram para a minha formação.

À todos colegas do Grupo de Pesquisa em História da Ciência e Ensino de Química, pelas conversas, discussões e conselhos, em particular ao Professor José Otávio Baldinato que por muitas vezes me auxiliou durante a elaboração desta dissertação.

Aos professores e colegas do IFSP que muito me ensinaram e a quem devo momentos memoráveis durante a graduação.

Ao CNPq pela concessão de bolsa, cujo apoio financeiro possibilitou a realização desta pesquisa. 


\section{Resumo}

\section{As demonstrações e experimentos químicos no Chemical Catechism de Samuel Parkes (1761-1825)}

No final do século XVIII e início do século XIX, manifestava-se na GrãBretanha um enorme entusiasmo pela ciência. Instituições como a Royal Institution foram fundadas com o objetivo de difundir o conhecimento por meio de palestras e demonstrações públicas de experimentos. Além do interesse pela utilidade no desenvolvimento de ofícios e produções, as maravilhas da ciência atraíam diferentes tipos de público, que viam as demonstrações como um passatempo divertido. Também conquistaram o gosto do público os livros de divulgação dos mais diversos ramos da filosofia natural, incluindo a química. Uma dessas obras de divulgação de maior sucesso foi o Chemical Catechism, de Samuel Parkes, publicado originalmente na Inglaterra em 1806, e que foi objeto de reedições e traduções em diversos países. O conteúdo químico apresentado nessa obra é abordado na forma de perguntas e respostas curtas, complementadas por extensas notas de rodapé, que apresentavam objetivos diversos. Um desses objetivos era guiar o tutor a fazer demonstrações e experimentos para os alunos, a fim de reforçar a parte catequética e convencê-los do caráter prático da ciência. Tendo como referencial a contemporânea historiografia da ciência, esta dissertação procurou contextualizar e caracterizar a forma como essas demonstrações e experimentos foram apresentados na obra de Parkes, bem como a sua importância para a divulgação da química no período.

Palavras chave: Samuel Parkes; Chemical Catechism; divulgação científica; divulgação da química; história da química. 


\section{Abstract \\ The Chemical Demonstrations and Experiments in Samuel Parkes' Chemical Catechism (1761-1825)}

In the late eighteenth century and early nineteenth century, there was a great enthusiasm for science in Britain. Institutions such as the Royal Institution were founded with the aim of spreading knowledge through lectures and public demonstrations of experiments. In addition to the interest in usefulness in the development of occupations and manufacturing, the wonders of science attracted different types of audiences, who saw demonstrations as entertainment. Also popular with the public were the popularizing books on the most diverse branches of natural philosophy, including chemistry. One of the most successful works of popularization was Samuel Parkes' Chemical Catechism, originally published in England in 1806, which was reprinted and translated in several other countries. The chemical content presented in this book is shown in the form of short questions and answers, complemented by extensive footnotes, which had different objectives. One of these aims was to guide the tutor in making demonstrations and experiments for students in order to reinforce the catechetical part of the book and convince them of the practicality of science. Having as a reference the contemporary historiography of science, this dissertation sought to contextualize and characterize the way these demonstrations and experiments were presented in Parkes' work, as well as their importance for the dissemination of chemistry in the period.

Key words: Samuel Parkes; Chemical Catechism; popularization of science; popularization of chemistry; history of chemistry. 


\section{llustrações}

Figura 1- Folhas de rosto da segunda e da quinta edições do Chemical Catechism, destacando as apresentações do autor (PARKES, 1807a, 1812)... .23

Figura 2- Folhas de rosto da oitava e da décima terceira edições do Chemical Catechism, destacando as apresentações do autor (PARKES, 1818, 1834). .24

Figura 3 - Sumário da segunda edição do Chemical Catechism. 27

Figura 4 - Dois padrões de texto - um com perguntas e respostas curtas, seguido das extensas notas de rodapé com informações adicionais (PARKES, 1807, p. 51).

Figura 5 - Gravura de aparatos químicos da primeira edição do Chemical Catechism, produzida com o uso de uma placa de vidro e ácido fluorídrico (PARKES, 1807b).

Figura 6 - Descrição dos aparatos químicos ilustrados na Figura 5 (PARKES, 1807b).

Figura 7 - Gravura de aparatos químicos da segunda e terceira edições do Chemical Catechism, produzida com o uso de uma placa de vidro e ácido fluorídrico (PARKES, 1807a, 1808).

Figura 8 - Descrição dos aparatos químicos ilustrados na Figura 7 (PARKES, 1807a, 1808).

Figura 9 - Ilustração do laboratório da Surrey Institution (PARKES, 1819) ..... 44

Figura 10 - Gravura de aparatos de laboratório, adicionada a partir da nona edição do Chemical Catechism (PARKES, 1819).

Figura 11 - Ilustração do laboratório da London Institution de Moorfields (PARKES, 1822). 


\section{Sumário}

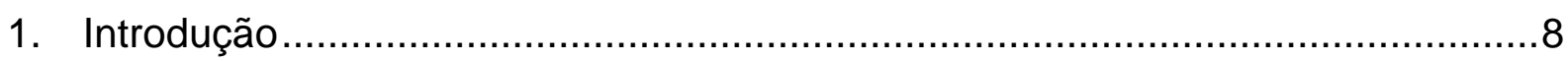

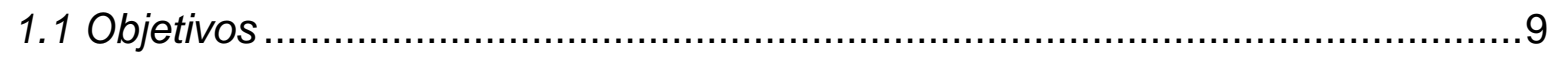

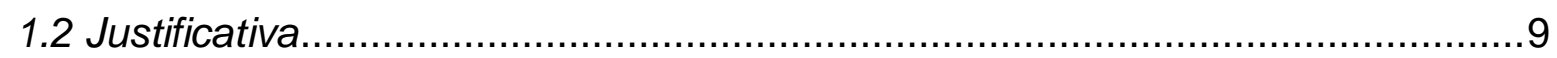

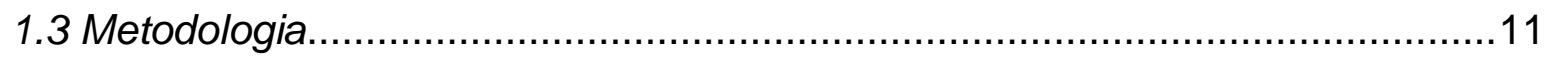

2. Capítulo I: A divulgação da ciência no início do século XIX: Parkes em seu contexto. 14

2.1 Os variados termos para a difusão de conhecimentos científicos..................14

2.20 interesse pela ciência na Inglaterra do início do século XIX.......................15

2.3 A divulgação científica em livros ..................................................... 19

2.4 Samuel Parkes - Vida e Obra ....................................................21

3. Capítulo II: Apresentando a química para o grande público: o Chemical Catechism...26

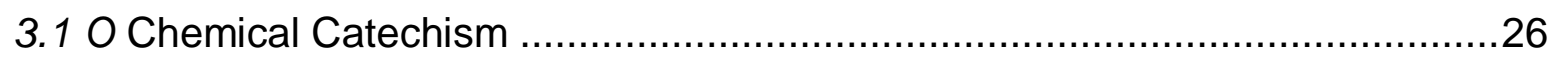

4. Capítulo III: Os experimentos e demonstrações químicas no Chemical Catechism. ...39

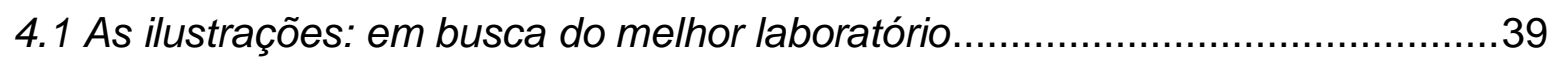

4.2 A química ad oculi: os experimentos no Chemical Catechism ......................50

4.2.1 Os experimentos nas notas de rodapé ............................................50

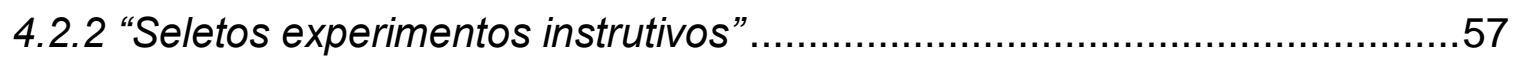

4.2.3 A química experimental, entre o maravilhoso e o útil...............................81

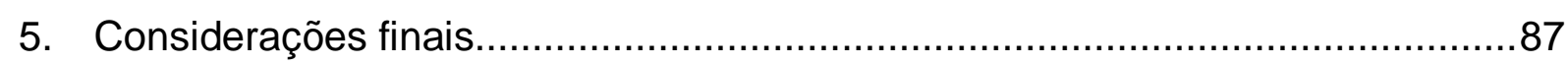

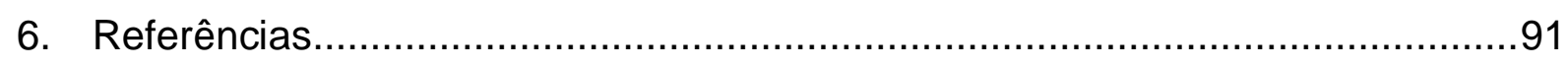

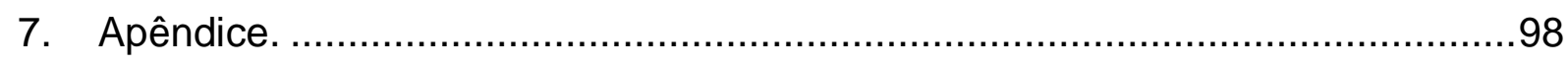




\section{Introdução}

No começo do século XIX, a Inglaterra passava por um período marcado por conflitos e pela crescente renovação dos processos de manufatura no contexto da Revolução Industrial. Tendo em vista a crescente necessidade de acompanhar os avanços experimentados pelo Reino, e impulsionada fortemente pelos adventos tecnológicos da época, a filosofia natural encontrou no Reino Unido lugar e momento propício para o seu desenvolvimento e divulgação. A Royal Institution pode ser citada como exemplo dentre as diversas sociedades filosóficas criadas nesse período, e tinha como objetivo difundir o conhecimento útil por meio de palestras e experimentos realizados em sua sede. Além de apelativas em termos de sua utilidade no desenvolvimento dos ofícios e produções, as maravilhas da ciência se mostraram atrativas para o público que procurava um passatempo que fosse interessante e divertido (JAMES; PEERS, 2007; KNIGHT, 2002).

Da mesma forma que as palestras, livros de introdução à química também receberam grande atenção daqueles que se interessavam pela ciência, alguns deles apresentando conceitos mais técnicos que, para o público iniciante, podiam ser de mais difícil compreensão (KNIGHT, 2002).

Uma dessas obras introdutórias que alcançou visível destaque no começo do século XIX é o Chemical Catechism, de Samuel Parkes (1761-1825). Essa obra se apresenta no formato de perguntas e respostas, acompanhadas por extensas notas de rodapé que serviam de complemento para a parte catequética do texto. Uma característica relevante é a de que, a cada nova edição do seu catecismo, Parkes atualizava alguns dos pontos abordados, conforme o desenvolvimento da química da época, procurando manter a obra atualizada e próxima da progressão da ciência em si. Isso mostra a proximidade entre a ciência produzida na época e o público geral, que acompanhava os avanços da ciência conforme as atualizações das obras de divulgação (KNIGHT, 1986, 2002; KURZER, 1997; PARKES, 1807a).

Um dos atrativos presentes na obra de Parkes são os experimentos propostos tanto nas notas de rodapé quanto em um capítulo especial dedicado às experimentações, no final do livro. Alguns desses experimentos foram indicados a 
Parkes pessoalmente por Humphry Davy, um dos mais célebres químicos e divulgadores de ciência do período. Na concepção de Parkes, os experimentos do Chemical Catechism foram propostos com o objetivo de estabelecer uma via de acesso à verdade que apenas a experimentação e a análise dos fatos poderiam estabelecer (PARKES, 1812).

\subsection{Objetivos}

Diante do panorama que abrange a divulgação da química por meio de livros no início do século XIX, buscamos nesta pesquisa investigar a forma pela qual a experimentação e demonstrações químicas são apresentadas no livro Chemical Catechism de Samuel Parkes, originalmente publicado na Inglaterra no ano de 1806, e traduzido para diversos idiomas posteriormente (KURZER, 1997).

O estudo deste tema visa contribuir para a reflexão a respeito de quão importantes eram os experimentos no âmbito das publicações concernentes à divulgação da química, e qual era o seu papel em uma época de grande fervor pela ciência em si - época na qual foram realizados importantes trabalhos químicos, como os de Humphry Davy (1778-1829) e Michael Faraday (1791-1867). O estudo visa também promover reflexões sobre como a divulgação científica e o próprio avanço científico de um período não se mostram imunes a influências da época e do lugar em que acontecem.

Assim sendo, as questões de pesquisa que orientaram este trabalho podem ser expressas como: Quais os recursos sensoriais mobilizados nos experimentos e demonstrações elencados por Parkes? Quais os conceitos apresentados nos experimentos, e qual o papel dos experimentos e demonstrações no contexto da divulgação proposta por Parkes?

\subsection{Justificativa}

No final do século XVIII e começo do século XIX, a divulgação da ciência estava em alta na Europa. Em Londres, plateias se aglomeravam para assistir às maravilhas que a ciência, e em especial a química, poderia ofertar com suas mudanças de cores, explosões e fenômenos aparentemente fantásticos. Em meio a 
essa sede pela ciência, a qual começava a adquirir certa especificidade em seu linguajar de acordo com seus avanços, livros de introdução aos diversos ramos da filosofia natural - incluindo a química - também conquistaram o gosto do público. Dois trabalhos que podemos elencar por introduzirem conceitos químicos para iniciantes e leigos na Inglaterra foram o Conversations on Chemistry de Jane Marcet(1769-1858) e o Chemical Catechism de Samuel Parkes, já que o seu relativo sucesso, apontado pelas sucessivas reedições, traduções e menções no decorrer do século XIX, indica certo destaque de tais obras na divulgação e aprendizado da química (KNIGHT, 1986; KURZER, 1997).

Dessa forma, a presente dissertação pretende oferecer uma contribuição para o melhor entendimento da imagem pública da química através dos tempos, bem como do vínculo estabelecido entre essa ciência e o público durante o século XIX. Além disso, ela também pode contribuir com a contextualização e caracterização da divulgação da química no início do século XIX, em particular, focalizando os experimentos encontrados no Chemical Catechism para aproximar - e maravilhar o público das ciências, aspectos nos quais ainda há muito a ser explorado e analisado (KURZER, 1997).

Por outro lado, o olhar voltado para a ciência do passado pode também promover reflexões acerca do ensino na atualidade, podendo ser útil no contexto da formação de professores e divulgadores da ciência. Tais reflexões podem ajudar a construir uma ideia de que a ciência não possui caráter imutável e eterno, e nem mesmo uma progressão linear, sendo passível de mudanças com o passar do tempo e do pensamento da sociedade na qual se constrói. Essas reflexões podem se mostrar úteis no âmbito da formação de professores, com potencial impacto positivo sobre a educação básica. Diante destes aspectos, a história da ciência tem sido cada vez mais empregada por professores e educadores como objeto de reflexão acerca da transformação dos conceitos sobre a Natureza (BELTRAN, 2014).

Segundo os Parâmetros Curriculares Nacionais para o Ensino Médio (PCNEM), referentes às Ciências da Natureza e suas Tecnologias, essa mudança é desejável, já que: "A consciência de que o conhecimento científico é assim dinâmico e mutável ajudará o estudante e o professor a terem a necessária visão crítica da ciência". Afinal, a ciência e os conceitos científicos não devem ser entendidos por 
estudantes e pelo público em geral como verdades eternas e absolutas, mas como conhecimentos em constante formulação e autocrítica (BRASIL, 2000, p. 31).

Já a Base Nacional Comum Curricular (BNCC), expressa que uma contextualização da ciência em âmbito social, histórico e cultural é fundamental para que a ciência seja vista como uma iniciativa humana. Segundo esse documento,

a contextualização histórica não se ocupa apenas da menção a nomes de cientistas e a datas da história da Ciência, mas de apresentar os conhecimentos científicos como construções socialmente produzidas, com seus impasses e contradições, influenciando e sendo influenciadas por condições políticas, econômicas, tecnológicas, ambientais e sociais de cada local, época e cultura (BRASIL, 2018, p. 550).

Entendendo-se então que uma análise das relações entre ciência, tecnologia, história e sociedade seja fundamental para o debate acerca do papel do conhecimento científico e da tecnologia na organização social e cultural (BRASIL, 2018).

\subsection{Metodologia}

A pesquisa aqui desenvolvida adota a contemporânea historiografia da ciência como referencial metodológico, abrangendo a análise de registros originais da época e trabalhos de historiadores da ciência para a contextualização do período em que o Chemical Catechism foi publicado. Para isso, foi feito um estudo de caso, levando em conta o contexto, o tempo e o espaço no qual o livro foi publicado, sendo os dados analisados tendo em vista o conhecimento e os valores vigentes no período (ALFONSO-GOLDFARB; BELTRAN, 2004).

Levando em conta que o nosso foco são os experimentos e demonstrações incluídos por Samuel Parkes em seu livro, procuramos analisar os experimentos do Chemical Catechism de acordo com as suas propostas, assim como procuramos posicionamentos do autor sobre a questão da experimentação na própria obra, de forma explícita ou implícita.

A necessária contextualização inclui a análise da divulgação científica do final do século XVIII e começo do século XIX, período que compreende a escrita e 
publicação do Chemical Catechism, a partir da bibliografia secundária já produzida por historiadores da ciência modernos, e uma caracterização do próprio Chemical Catechism em si (KNIGHT, 1986, 2007, 2009; TOPHAM, 2000).

A pesquisa, assim, utiliza como fonte os textos originais de Samuel Parkes, encontrados em formato digital na base de dados Google Books, Internet Archive e HathiTrust, ou seja, documentos primários, levando em conta as diversas edições e ressaltando as modificações inseridas conforme o avanço das descobertas científicas da época. As fontes de pesquisa incluem ainda as críticas feitas na época ao Chemical Catechism em periódicos locais (também encontrados nas bases de dados digitais referidas acima) como The Monthly Review, bem como fontes secundárias, que compreendem trabalhos de historiadores da ciência como David Knight (1986, 2002, 2007, 2009), Frank James (2007), Frederick Kurzer (1997), Jonathan R. Topham (1998, 2000, 2009), Jean-Luc Chappey (2004), Jan Golinski (1999) e Bernard Lightman (1997, 2007). As fontes secundárias, em sua maioria, foram encontradas por meio do mecanismo de busca Google Acadêmico, fazendo uso de palavras-chaves como: textbook, Samuel Parkes, popularization of chemistry, com outras palavras-chaves indicativas de tempo, como Victorian Britain e nineteenth-century.

Dessa forma, buscamos critérios de análise consistentes com a época na qual - Chemical Catechism foi publicado, evitando assim um olhar anacrônico. Isso permite que o estudo e a análise da ciência do passado sejam expostos de forma mais fidedigna, levando em conta uma gama maior de fatores, como questões sociais, pessoais, históricas, econômicas, culturais e religiosas que possam ter vindo a influenciar o autor e sua obra, para que se possa alcançar um melhor entendimento do contexto tratado e das especificidades que influenciaram o pensamento e a construção da ciência no período.

A presente dissertação foi estruturada em três capítulos. O primeiro traz uma pequena abordagem da opção pelo termo "divulgação" em detrimento de outros termos encontrados na literatura, o contexto da época do lançamento do Chemical Catechism, bem como alguns dados biográficos sobre Samuel Parkes. No segundo capítulo, trazemos uma análise do livro Chemical Catechism, sua estruturação e sua recepção. Já o terceiro capítulo traz uma análise das imagens de laboratórios e instrumentos encontradas em diferentes edições do livro, e uma discussão sobre os 
experimentos presentes no Chemical Catechism, buscando caracterizar os objetivos e estratégias adotadas por Parkes. Esse capítulo é seguido por algumas considerações finais. 


\section{Capítulo I: A divulgação da ciência no início do século XIX: Parkes em seu contexto.}

\subsection{Os variados termos para a difusão de conhecimentos científicos}

Quando tratamos de práticas de comunicação de assuntos científicos para um público amplo, é comum encontrarmos uma variedade de termos aparentemente similares: vulgarização, popularização, divulgação, difusão e comunicação científica. Embora a princípio esses termos possam ser tratados como sinônimos de uma mesma prática de difusão e acesso de conhecimentos científicos, eles implicam práticas e significados díspares (GERMANO; KULESZA, 2007).

De acordo com Massarani (1998, p. 14), a expressão "vulgarização da ciência" surgiu na França no começo do século XIX. Porém, ainda naquele século, encontrou certa resistência devido a um possível entendimento conotativo pejorativo quando relacionado à palavra "vulgar" (do latim vulgare), e não à ideia de povo (do latim vulgus). Dessa forma, não demorou a surgir um segundo termo, "popularização", que, embora tenha sido bastante aceito e usado nos países de língua inglesa na forma de "popularization of science" ${ }^{1}$, não foi bem aceito na comunidade científica francesa da época, e nem mesmo conseguiu ofuscar o termo "vulgarização" na França (GERMANO; KULESZA, 2007; KNIGHT, 2002).

No Brasil, os termos "vulgarização" e "popularização" foram muito utilizados no passado: o primeiro foi comum no século XIX e começo do século $X X$, e o segundo foi frequentemente usado nas décadas de 1960 e 1970. Porém, atualmente, o termo hegemonicamente utilizado no Brasil é "divulgação", encontrado em diversos meios de comunicação (GERMANO; KULESZA, 2007; MASSARANI, 1998).

Segundo Estrada (1992, p. 69-70), a "divulgação da ciência" tem o papel de apresentar a ciência para o público em geral, incluindo aí os cientistas especialistas em áreas diferentes daquela divulgada, para que estes tomem conhecimento sobre o que acontece nas demais áreas nas quais não atuam. A "difusão da ciência", por

\footnotetext{
${ }^{1}$ De acordo com Lightman (2007, p. 11-12), a expressão "popularization of science" recebeu diferentes interpretações sobre o seu uso, significado e aplicabilidade, conforme quem a aplicasse ou interpretasse, podendo o significado ser negativo ou positivo. Para aqueles que administravam a Royal Institution, por exemplo, a "popularização" era vista como uma forma de atrair grandes audiências e de atrair investimentos que viessem a ser proveitosos para a instituição.
} 
sua vez, seria o compartilhamento, entre especialistas, dos resultados de suas pesquisas, com caráter elaborado, por meio de publicações e congressos científicos. Ainda conforme Estrada, embora muito diferentes em seu princípio, a difusão e a divulgação têm em comum a ideia de que o público destinatário do conhecimento científico o recebe de maneira passiva, sem a possibilidade de diálogo, sem o "intercâmbio de saberes e experiências" (ESTRADA, 1992, p. 70). Caso comunicação bilateral esteja envolvida no compartilhamento científico a ponto de que haja troca de conhecimentos, este processo é denominado "comunicação científica".

Sendo assim, tendo em vista que esta dissertação tem como objeto de investigação um livro de introdução à química para o público geral do começo do século XIX, optamos pelo uso do termo "divulgação da química" em sua redação, não apenas por este ser o termo predominantemente usado no Brasil, mas também por possuir a conotação e denotação que mais se assemelha aos objetivos da obra a ser analisada. Por esse motivo, os termos popularization of science em inglês e vulgarisation scientifique em francês, encontrados na literatura secundária, serão aqui traduzidos como "divulgação da ciência" (CHAPPEY, 2004; KNIGHT, 2002; MASSARANI, 1998).

\subsection{O interesse pela ciência na Inglaterra do início do século XIX}

Durante a segunda metade do século XVIII e a primeira metade do século XIX, a ciência era vista com intenso entusiasmo e popularidade na Grã-Bretanha. A química, em especial, representava grande parte desse fascínio que, segundo Knight (2009), talvez tenha encontrado nessa época o auge de sua notoriedade, sendo vista não apenas como uma curiosidade divertida de grande apelo sensorial, mas também como uma necessidade e uma preocupação (KNIGHT, 2007).

O apelo científico era tão grande que, em 1825, o político Charles Hindley (1825, p. 499) escreveu para a Edinburgh Review afirmando que "a sagrada sede por ciência estava se tornando epidêmica", e que logo chegaria o dia em que as leis da ciência seriam conhecidas por todos os homens, e o conhecimento científico não mais seria restrito a "poucas mentes superiores". Até mesmo aqueles que não viam a nova ciência com bons olhos e não estavam tão dispostos a aceitar seus avanços, 
segundo Sir Henry Holland (1788-1873), médico membro da Royal Society e presidente da Royal Institution por oito anos, se sentiram forçados a adquirir algum nível de conhecimento sobre ela (CROOKES, 1873; HOLLAND, 1872).

Por mais que o período tenha de fato sido marcado por um grande interesse pela química, o seu estudo evidentemente não era algo novo. Por muitos séculos, os conhecimentos químicos permearam não apenas as técnicas empregadas nos mais diferentes ofícios, como os envolvidos no manejo de metais, minerais e preparados de origem animal e vegetal para fins curativos, mas também os estudos da filosofia natural (GOLINSKI, 1999). Além disso, a química já fazia parte do currículo acadêmico de algumas universidades e instituições educacionais da Europa havia algumas décadas, porém, de acordo com Golinski (1999), foi em meados do século XVIII que a química começou a apresentar de fato o caráter popular que a compeliu a um âmbito propício de divulgação científica.

Em A System of Chemistry (1804, p. 12), Thomas Thomson (1773-1852) credita a difusão da química na França durante aquele século em grande parte a Guillaume-François Rouelle (1703-1770), que em 1742 se tornou professor de química no Jardim das Plantas em Paris e começou a difundir dentro dos círculos eruditos franceses o seu próprio entusiasmo pelo assunto, tornando assim o estudo pela química uma verdadeira tendência.

Essa tendência, segundo Thomson, se espalhou pela Europa: estudiosos despontaram pela França, o número de descobertas se avolumou e logo em outros países também se desenvolveu o interesse pelo assunto, como na Itália. Ainda segundo Thomson, após a morte de Boyle (1627-1691), pouca atenção foi dada à química nos círculos ingleses - salvo alguns poucos indivíduos - devido ao interesse que os estudos de Newton acerca das ciências matemáticas despertaram junto à maioria dos "homens de eminência" da Grã-Bretanha. Isso teria mudado, no entanto, quando William Cullen (1710-1790) assumiu a cadeira de química na Universidade de Edimburgo em 1756, e semeou entre os seus alunos o interesse pela química, que logo se difundiu com os trabalhos posteriores de Joseph Black (1728-1799), Henry Cavendish (1731-1810) e Joseph Priestley (1733-1804) (GOLINSKI, 1999; THOMSON, 1804).

Segundo Golinski (1999, p. 52), por ação conjunta de Cullen e de seus simpatizantes, a química alcançou um lugar de notoriedade na educação 
universitária escocesa e conseguiu convencer aos poucos os seus patrocinadores de sua utilidade e potencialidade econômica. A ascensão da química na Inglaterra, no entanto, segundo autores como Kurzer (2000), James (2007), Cutler (1976) e Knight $(2002,2009)$, teve o seu impulso por motivos de natureza diferente.

No final do século XVIII, a França se encontrava em um período de intensa agitação política e social, e também vivia intensa agitação científica. Envolvida em conflitos internos e externos, ela dependia da ciência para aperfeiçoar bens e processos relacionados aos propósitos bélicos, ao mesmo tempo em que a Inglaterra necessitava de aperfeiçoamentos científicos para aprimorar técnicas voltadas à sua autossuficiência (KNIGHT, 2002).

A Inglaterra, especialmente em função dos conflitos com a França (que, após o furor da Revolução Francesa, se envolveu no que foi chamado mais tarde de guerras revolucionárias francesas e nas guerras napoleônicas subsequentes), teve o seu acesso ao comércio continental reduzido e limitado. Viu-se, então, forçada a confiar apenas em seus próprios recursos para a subsistência de suas manufaturas, cada vez mais exigentes devido ao avanço da industrialização (JAMES; PEERS, 2007; KNIGHT, 2002). Dessa forma, segundo Knight (2002, p. 74), "a França, por volta de 1800, liderou o mundo em ciência, mas a Grã-Bretanha liderou o mundo em tecnologia".

De acordo com Kurzer (2000), durante o começo do século XIX, a Inglaterra encontrava-se mergulhada em um período de intensa industrialização que estava mudando significativamente o país, período este conhecido como Revolução Industrial. Ainda segundo ele, com o avanço das técnicas de manufatura, crescimento do comércio e acúmulo de capital, houve ascensão de uma grande classe social de ricos fabricantes, comerciantes e banqueiros que, em parte, também foram aos poucos convencidos da utilidade do avanço científico para fomentar seus objetivos econômicos.

Em meio a esse contexto histórico e social, ao mesmo tempo em que representava um caminho promissor para o desenvolvimento tecnológico necessário para a manufatura do Reino Unido, a ciência também encantava plateias com demonstrações de explosões, mudanças de cores e produção de odores. O público se aglomerava em auditórios para assistir às maravilhas que a ciência poderia apresentar (KNIGHT, 2007, 2009). 
Uma das instituições que se destacou na apresentação da ciência ao público foi a Royal Institution, fundada em 1799 com o objetivo de

difundir o conhecimento e facilitar a introdução de invenções e melhoramentos mecânicos úteis; e para ensinar, por meio de cursos com palestras filosóficas e experimentos, a aplicação da ciência aos propósitos cotidianos da vida (JAMES; PEERS, 2007, p. 141).

As palestras sobre ciência atraíam um público de diversas idades e de ambos os sexos, como foi notado pelo químico americano Benjamin Silliman (1779-1864) (1812, p. 211), interessado nas maravilhas que a ciência, em especial, a química, poderia apresentar. Isso pode ser observado no diário do jovem viajante francês Louis Simond, que documentou sua visita a Londres nos anos de 1810 e 1811 . Em seu diário, Simond escreveu que, embora muitos fossem os assuntos abrangidos pelas palestras apresentadas na Royal Institution, como astronomia, mecânica e história natural, essas ciências não eram tão populares como a química. Segundo Simond, essas áreas não eram tão atraentes por não serem "suscetíveis a exposições brilhantes; não há barulho nem fogo - e o anfiteatro nunca se enche a não ser para o Sr. Davy" (SIMOND, 1817, p. 43).

Embora as palestras representassem a principal via de atuação da Royal Institution, percebeu-se, com o passar do tempo, que elas não eram suficientes em si, e que a instituição necessitava ampliar seu apelo junto ao público. Assim, não demoraram a se popularizar os grandes experimentos científicos apresentados para o público, cuja execução, muitas vezes, era perigosa pelos nossos atuais padrões de segurança (JAMES; PEERS, 2007). Esse esforço em levar a ciência a um grande público e demonstrá-lo de forma apelativa, objetivando um aprendizado prático, foi um dos aspectos que marcou a divulgação da ciência durante esse período (KNIGHT, 2002).

De acordo com Golinski (1999), duas linhas de pensamento sobre como a divulgação da ciência deveria ser apresentada e utilizada podem ser elencadas, sendo as duas bem diferentes em seus propósitos. A primeira, que abrangia uma minoria de autores, era movida por um ideal mais radical, sendo impulsionada principalmente pelos ideais iluministas. Nesse grupo, encontravam-se nomes como 
Joseph Priestley (1733-1804) e Thomas Beddoes (1760-1808), que defendiam a visão de uma filosofia natural útil, ligada a aspectos políticos. Essa filosofia natural, ao ser empregada pela população, seria uma poderosa ferramenta para compreender o Universo, podendo pôr fim à autoridade indevida e usurpada pela nobreza. Ao seguir essa linha de pensamento, Priestley foi um dos líderes do movimento que pedia uma reforma do Parlamento britânico, mas acabou sendo forçado ao exílio nos Estados Unidos na década de 90 do século XVIII. O segundo grupo era formado pela grande maioria dos filósofos naturais das regiões industrializadas da Inglaterra, e buscava manter os radicais afastados das instituições científicas nacionais, combatendo os chamados ideais "jacobinos" (GOLINSKI, 1999, p. 163). A divulgação da ciência, para este segundo grupo, tinha como objetivo entreter e instrumentalizar o trabalhador para que viesse a exercer a sua função de forma ainda melhor, cooperando para que o sistema hierárquico então presente fosse mantido (GOLINSKI, 1999; KNIGHT, 2002; KRAMNICK, 1986).

\subsection{A divulgação científica em livros}

Juntamente a esse interesse crescente pela ciência, que estimulava as instituições a oferecerem cada vez mais palestras científicas para seu público, também ocorreu um aumento significativo no número de publicações científicas durante o século XIX. Um dos motivos que levaram a essa expansão gradual foram os avanços tecnológicos que se deram, principalmente, durante a primeira metade do século (TOPHAM, 2000).

Até o começo do século XIX, os livros eram tidos como verdadeiros artigos de luxo, já que eram impressos em prensas operadas manualmente e ilustrados com o uso de placas de metal, o que encarecia o seu preço. Somente a partir de 1820 que a literatura, fosse ela de base filosófica ou não, veio a ter um impulso mais considerável graças à evolução das técnicas de imprensa e produção em massa, como a prensa rotativa movida a vapor e o aprimoramento de técnicas de produção de papéis mais baratos e mais acessíveis (KNIGHT, 2002).

No decorrer da década de 1840, a produção de livros já havia evoluído de tal forma que a circulação de obras era quatro vezes maior que no começo do século. Com o advento de tais técnicas, os jornais, já comuns ao início do século, se 
tornaram mais populares e numerosos, tornando assim a Inglaterra uma das pioneiras na produção massiva de publicações impressas (KNIGHT, 1986, 2002; LIGHTMAN, 2007).

Outro fator que se deve certamente considerar é que, segundo Knight (2002, p. 75), embora boa parte da população ainda fosse analfabeta naquela época, havia uma demanda cada vez maior de obras literárias por parte daqueles que compunham a camada da população que possuía uma mínima instrução, a mesma camada que tendia ver a ciência como um assunto consideravelmente interessante, o que ajudou a impulsionar a publicação das obras de divulgação científica.

Dentre as obras de divulgação da química publicadas na época, tiveram destaque, se considerarmos o número de edições e traduções para outros idiomas, os livros Conversations on Chemistry, de Jane Marcet e Chemical Catechism, de Samuel Parkes, publicados ambos em 1806. O objetivo dessas obras era apresentar conceitos básicos da química da época para aqueles que dela nada, ou pouco, sabiam, principalmente crianças e jovens. Embora Marcet deixe claro em seu prefácio que tinha o público feminino como alvo ao escrever Conversations on Chemistry, relatos da época revelam que seu livro atingiu um público muito mais amplo do que aquele ao qual era direcionado. Por outro lado, Parkes afirmou ter como motivo inicial para a redação do Chemical Catechism a educação de sua única filha; porém, ao perceber que sua obra alcançou dimensão muito maior do que a esperada inicialmente, e incentivado por amigos, decidiu publicar seu livro para ajudar na instrução das crianças, que poderiam utilizar o conhecimento químico para impulsionar e aprimorar quaisquer atividades a que viessem se dedicar no futuro (KNIGHT, 1986, 2002; KURZER, 1997; BALDINATO, 2015).

É interessante ressaltar, no entanto, que a forma pela qual os dois autores apresentaram a química em suas obras é bem diferente de livros anteriores dessa mesma ciência, e as abordagens também são diferentes uma da outra, embora seus formatos já fossem empregados em publicações de outras áreas. Para Lightman (2007), os novos formatos adotados para a divulgação provavelmente tinham como objetivo tornar o aprendizado da química tão atrativo quando a ficção em prosa, imensamente popular na época, para que assim se pudesse incluir em seu público novas classes de leitores. 
Quanto ao formato, enquanto Marcet escreveu seu texto em forma de diálogo, utilizando-se de três personagens - duas garotas, Caroline e Emily, e sua tutora, Sra. B. - , Samuel Parkes utilizou o formato de catecismo (KNIGHT, 1986). Segundo Parkes, esse formato fora escolhido porque "[...] possui ao menos todas as vantagens que qualquer outro método de instrução química à juventude reivindica". Desta forma, o aprendizado do pupilo seria garantido, já que "se a intenção original do autor for seguida, o aprimoramento progressivo do estudante será agradável, rápido e correto" (PARKES, 1808, p. xii).

\subsection{Samuel Parkes - Vida e Obra}

Pouco se sabe sobre a vida de Samuel Parkes até o ano de 1803, ano em que ele se mudou com a família para Londres. Sabe-se que ele nasceu em Stourbridge, Worcestershire, no interior do Reino Unido, em 26 de maio de 1761, e era filho de Samuel e Hannah Parkes. Aos cinco anos de idade, começou a frequentar uma escola infantil de sua cidade, e aos dez foi enviado para ser pupilo de Stephen Addington² (1729-1796), permanecendo sob sua tutela até os quatorze anos. Após passar pela rápida tutela de um ferreiro em Ross-on-Wye, Samuel Parkes retornou a Stourbridge, se juntou a seu pai e passou os subsequentes 18 anos de sua vida ajudando-o em seus negócios. Samuel Parkes, desde cedo, mostrou-se um ávido leitor e colecionou muitos livros que futuramente formariam a sua biblioteca pessoal, consolidando assim a sua educação por meio da leitura, já que não veio a frequentar uma universidade. Por volta de 1790, Parkes ajudou a montar uma biblioteca pública em Stourbridge, em que ele próprio atuou como administrador por alguns anos. Nessa mesma época, Parkes auxiliou na criação de uma capela destinada ao culto do Unitarismo em sua cidade (HODGETTS, 1826; KURZER, 1997) ${ }^{3}$.

\footnotetext{
${ }^{2}$ Stephen Addington, D.D., foi professor e ministro independente em Market Harborough, onde conduziu uma escola e recebeu pupilos durante vinte e três anos (1758-1781). Mudouse então para Londres, vindo mais tarde a atuar como tutor na Mile End Academy. Addington também publicou livros didáticos sobre Aritmética, Geografia e Gramática grega, assim como foi o autor de muitos textos na área de teologia (KURZER, 1997; MCLACHLAN, 1931).

${ }^{3} \mathrm{Em}$ 1826, um obituário foi publicado em honra a Parkes no The Monthly Repository of Theology and General Literature, assinado apenas com um "H". Kurzer (1997, p. 432), em seu artigo sobre Samuel Parkes, atribuiu a autoria de tal nota biográfica ao genro de Parkes, Joseph Wainwright Hodgetts.
} 
Em 1793, com 32 anos, Parkes se mudou para Stoke-on-Trent, onde deu início a um negócio de fabricação de sabão e casou-se com Sarah Twamley (17661813). Em 1797, nasceu sua única filha, Sarah Mayo. Segundo Kurzer (1997), a produção de sabão e seu interesse em controlar o processo de fabricação de forma mais eficaz direcionou Parkes ao estudo da química, atividade que veio a se tornar seu grande interesse profissional (BALDINATO, 2015; HODGETTS, 1826; KURZER, 1997).

Após um contratempo financeiro, Parkes mudou-se com sua família para Londres em 1803. Dispondo de um empréstimo feito por um amigo e mais uma pequena quantia própria, estabeleceu-se na cidade e iniciou sua carreira como fabricante de produtos químicos. Após apenas três anos do início de seu empreendimento, Parkes conseguiu saldar todos os débitos contraídos, o que indica o significativo sucesso de seu novo ofício. Todavia, embora a atividade como fabricante de produtos químicos exigisse de sua parte grande atenção e dedicação, isso não o impediu de continuar estudos e pesquisas de seu interesse. Em 1806, Parkes publicou a primeira edição do Chemical Catechism, em 1809 o Rudiments of Chemistry e, em 1815, publicou seu terceiro livro, o Chemical Essays (HODGETTS, 1826; KURZER, 1997).

O sucesso profissional de Samuel Parkes durante o começo do século XIX pode ser acompanhado pelas folhas de rosto das sucessivas edições de seus livros, observando-se a forma como ele se apresenta, como foi notado por Kurzer (1997). Ao comparar a folha de rosto da segunda edição, de 1807, e da quinta edição, de 1812, do Chemical Catechism, já é possível perceber uma significativa mudança (Figura 1). Na folha de rosto da segunda edição, Parkes identifica-se apenas como "fabricante de produtos químicos" (PARKES, 1807a), enquanto na quinta edição ele se identifica de forma mais ampla: "autor do Rudiments of Chemistry e um dos proprietários da fábrica de produtos químicos Haggerstone, Londres" (PARKES, 1812, p. i). 


\section{CHEMICAL CATECHISM, CHEMICAL CATECHISM, \\ wrrt}

COPIOUS NOTES,

VOCABULARY OF CHEMICAL TERMS,

USEFUL TABLES,

$A \times D$

A CHAPTER

or

INSTRUCTTVE AND AMUSING EXPERIMENTS.

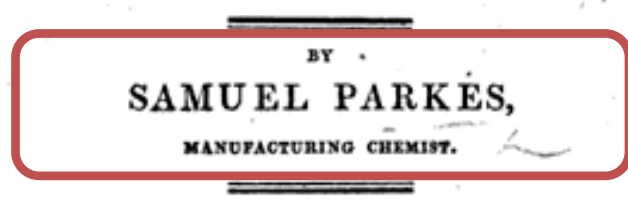

THE SECOND BDITION,

WITH CONSHDERALE ADDITIOXs.

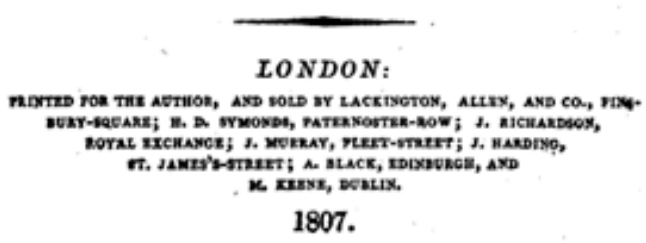

NOTES, ILLUSTRATIONS,

AND

EXPER IMENTS.

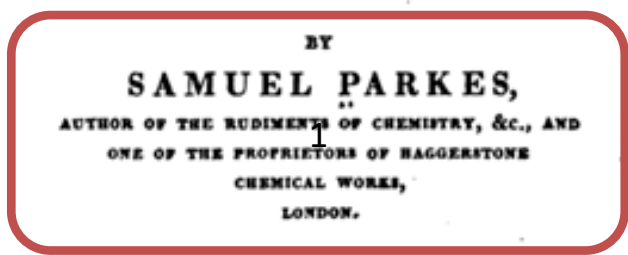

THE FIFTH EDITION,

CONTATSDS THE NEW DISCOVERIS AND OTHER COSSIDERABLE ADDITIOKS.

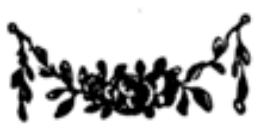

LON DON :

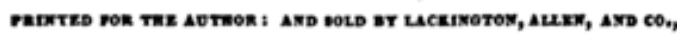

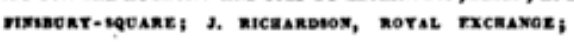

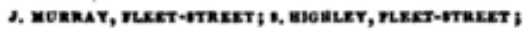

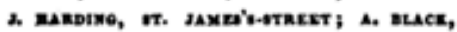

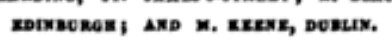

1812.

Figura 1- Folhas de rosto da segunda e da quinta edições do Chemical Catechism, destacando as apresentações do autor (PARKES, 1807a, 1812).

Ao comparar a quinta edição e a oitava, de 1818, e esta com a décima terceira edição (póstuma), no entanto, nota-se uma diferença ainda maior (Figura 2). Após obter significativo reconhecimento profissional, Parkes não mais citou suas atividades como químico de preparação nas folhas de rosto de seus livros, mas sim extensas listas de afiliações. Na oitava edição, por exemplo, Parkes se identifica como membro da Sociedade Linneana de Londres ("F.L.S."), membro da Royal Institution ("M.R.I."), "membro da Sociedade Geológica de Londres, da Sociedade Highland da Escócia; e da Sociedade Caledônia de Horticultura de Edimburgo" (PARKES, 1818, p. i). Na décima terceira edição (PARKES, 1834, p. i) ele ostenta uma ainda mais extensa lista de títulos pessoais recebidos no decorrer dos anos e publicações, além de afiliações a academias e sociedades filosóficas. 
THE

\section{CHEMICAL CATECHISM,} พrra

NOTES, ILLUSTRATIONS,

AND

EXPERIMENTS.

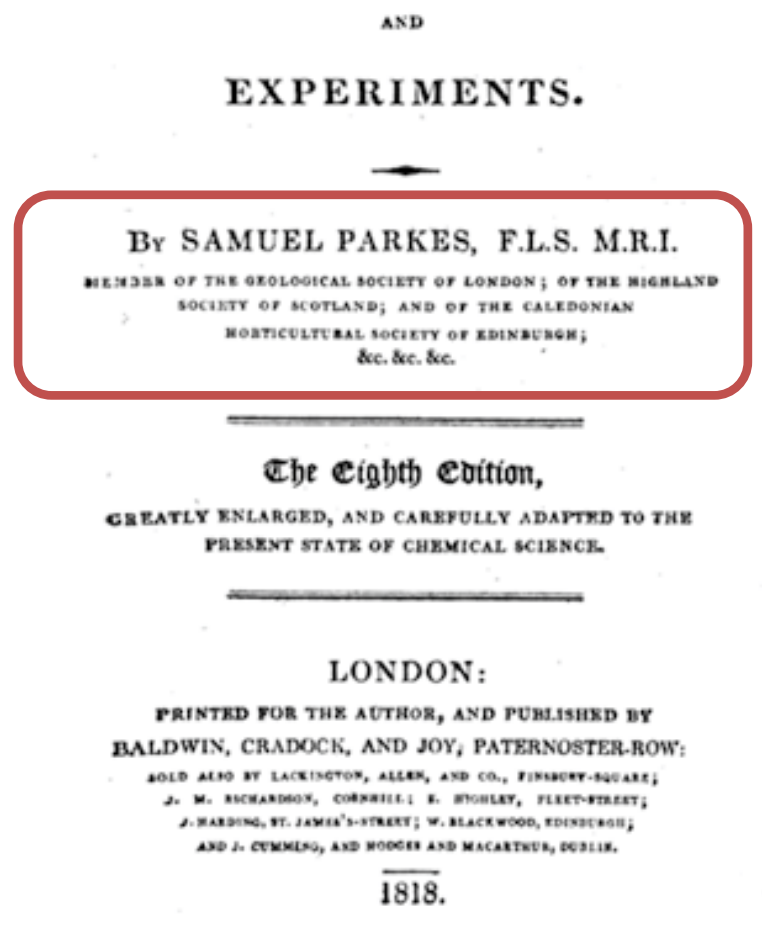

THE

\section{CHEMICAL CATECHISM,}

THIRTEENTH EDITION.

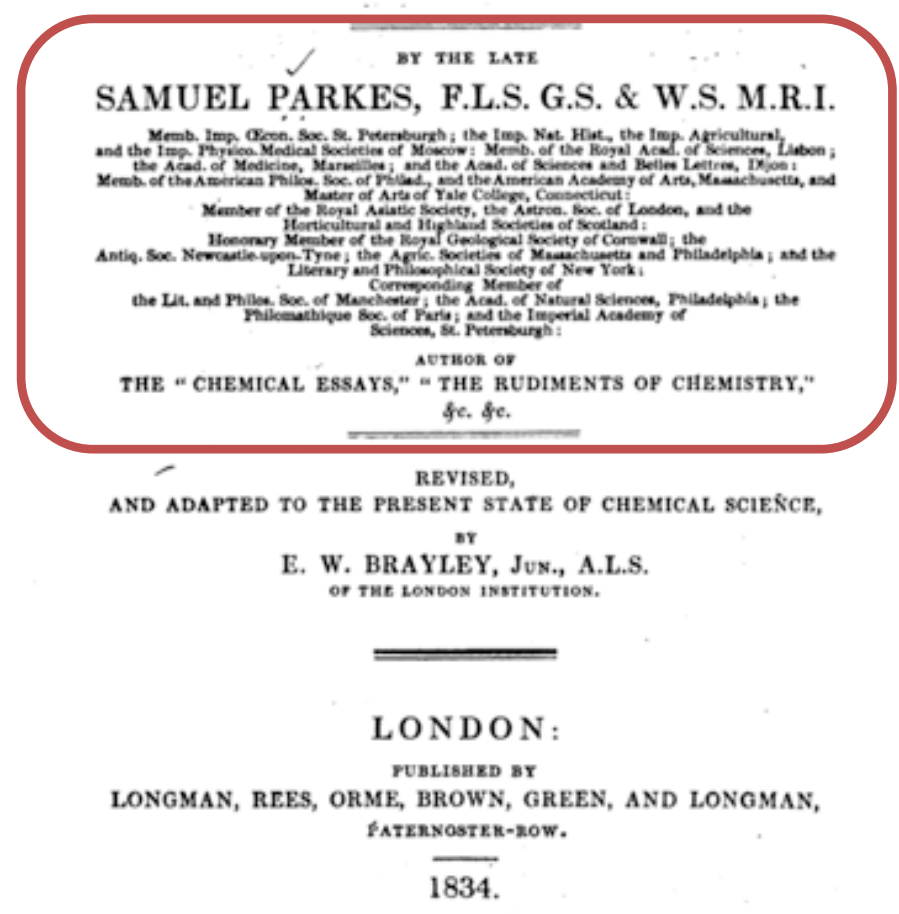

Figura 2- Folhas de rosto da oitava e da décima terceira edições do Chemical Catechism, destacando as apresentações do autor(PARKES, 1818, 1834).

Além das obras anteriormente citadas, Parkes também publicou pequenos textos, que muitas vezes tratavam de química e sua utilidade nas questões de interesse econômico do Reino Unido, como o Thoughts on the Salt Laws (1817) e Letter to Farmers and Graziers on the Use of Salt in Agriculture (1819). Ademais, devido a seu conhecimento nas áreas práticas da química, Parkes também participou, por diversas vezes, de audiências jurídicas e parlamentares como testemunha ou consultor especialista. Um conhecido caso em que Parkes tomou parte como especialista, ao lado de outros famosos químicos da época, foi o de um incêndio ocorrido em uma refinaria de açúcar em 1819. De um lado, a empresa Messrs Severn King \&Co. solicitava a indenização de setenta mil libras devido ao incêndio, enquanto a Companhia de Seguros Imperial defendia que a causa do 
incidente ocorrido se encontrava fora da lista de riscos cobertos pela apólice do seguro contratado (HODGETTS, 1826; KURZER, 1997).

Após a morte de sua esposa de forma inesperada, em 1813, Parkes contou com o auxílio de sua filha para administrar a casa e acompanhá-lo em algumas de suas viagens. Em junho de 1825, um ano depois do casamento de sua filha com Joseph Wainwright Hodgetts (1797-1851), Parkes adoeceu severamente durante uma viagem para Edimburgo e, assim que foi considerado prudente, foi levado pelo genro de volta para Londres. Após meses de enfermidade, no entanto, Parkes faleceu no dia 23 de dezembro de 1825 (HODGETTS, 1826).

Dentre os trabalhos de Parkes, o Chemical Catechism sem dúvida foi o que alcançou maior repercussão, irradiando seu nome através de sucessivas edições e traduções que o levaram para além das fronteiras da Inglaterra. O capítulo seguinte traça um perfil do Chemical Catechism. 


\section{Capítulo II: Apresentando a química para o grande público: o Chemical Catechism}

\subsection{O Chemical Catechism}

Com o título de A Chemical Catechism for the use of Young people, a primeira edição da obra mais popular de Parkes foi lançada em maio de 1806, com uma tiragem de mil e quinhentas cópias - a menor, em comparação com as tiragens das edições subsequentes. O Chemical Catechism teve um total de treze edições, sendo doze delas lançadas entre os anos de 1806 e 1826. A décima terceira edição foi lançada postumamente no ano de 1834, após revisão e adaptação por Edward William Brayley, da London Institution (KURZER, 1997). Sob o título de A Catechism of Chemistry, outras duas edições do livro de Parkes foram lançadas em 1837 e 1854, revisadas e editadas por W. Barker, do Trinity College de Dublin. Essas duas edições tiveram suas notas de rodapé consideravelmente reduzidas em comparação com o livro original, e a organização de alguns dos capítulos foi alterada (KURZER, 1997; PARKES, 1837, 1854).

Dividido em capítulos com diferentes temáticas (Figura 3), o Chemical Catechism tem o seu início com o que, dependendo da edição, recebeu o título de "Um ensaio sobre a utilidade do estudo da química para as artes e manufaturas" (PARKES, 1807a) - embora, no sumário, o título dessa seção seja apresentado apenas como "um ensaio sobre a utilidade do estudo da química para as artes", conforme se pode observar na Figura 3 - ou, ainda, como "um ensaio sobre a utilidade do estudo da química" (PARKES, 1818, p. 1). Nessa seção de abertura, Parkes argumenta em favor da importância do estudo da química para as atividades a que os jovens viessem a se dedicar no futuro. 


\section{CONTENTS.}

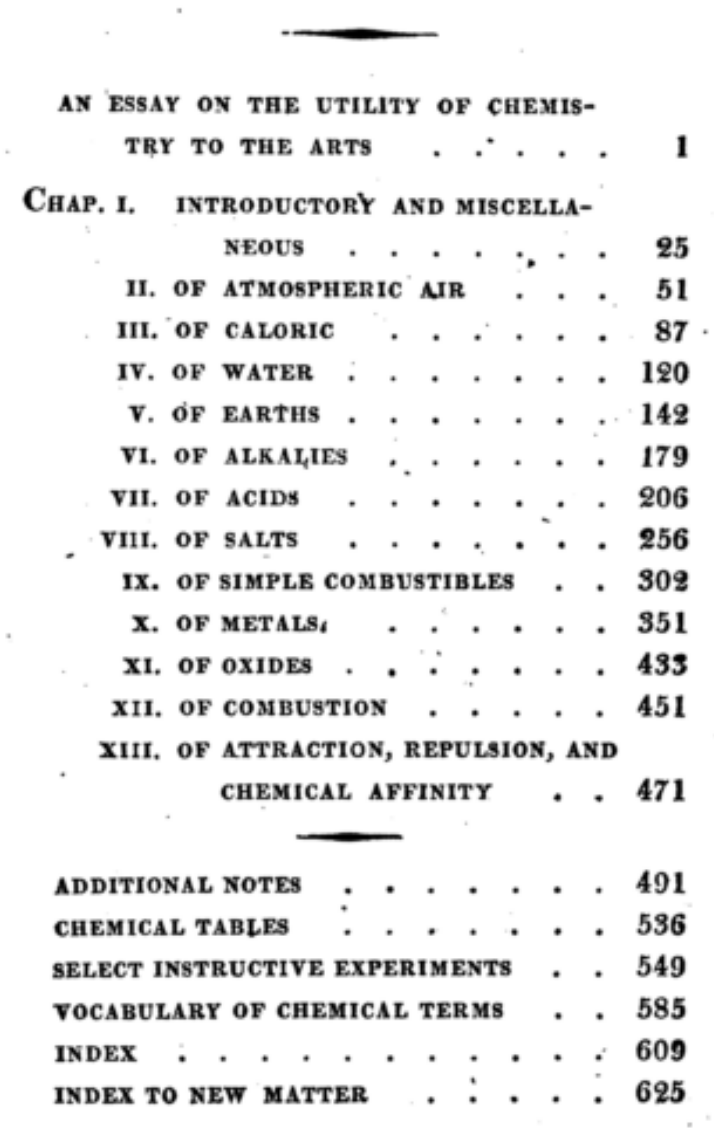

Figura 3 - Sumário da segunda edição do Chemical Catechism.

Como dito anteriormente, embora tenha sido pensado originalmente como um livro para a sua filha, o público final para o qual o Chemical Catechism foi endereçado por Parkes foi o público masculino. No ensaio inicial de sua obra, ele direciona aos pais argumentos sobre o uso da química em benefício do desenvolvimento da futura profissão de seus filhos. Parkes argumenta que as informações ali colocadas tinham como objetivo ensinar química aos jovens, para que, se eles tivessem terras, pudessem utilizar a química para seu melhor aproveitamento e exploração; ou, se o jovem pretendesse ingressar na medicina, que pudesse entender os princípios da química e usá-los em sua profissão; ou ainda, para que aqueles que desejassem se aventurar pela indústria, o conhecimento químico definitivamente seria de enorme valor para a execução de suas funções (KNIGHT, 1986; KURZER, 1997; PARKES, 1812).

O primeiro capítulo, intitulado "Introdutório e Miscelânea", como o próprio nome sugere, inclui uma miscelânea de ideias que buscam caracterizar a química, 
sua função, formas de utilização e princípios básicos. Nele, o autor procura introduzir os conceitos mais simples sobre a química, antes de avançar para os capítulos mais específicos e aprofundados. O capítulo aborda de forma dogmática o que é a química e a forma com que os químicos analisam as propriedades dos corpos, discorrendo em seguida sobre conceitos introdutórios como, por exemplo, o que é decomposição, o que é calor, quais são os estados dos corpos naturais, suas diferenças e definições, bem como suas propriedades. Nesse capítulo, também se encontra a introdução de alguns conceitos como os de gravidade específica e atmosfera, assim como explanações sobre como se formaria a chuva, o granizo e a neve (PARKES, 1807a).

Os capítulos seguintes, que constituem a maior parte do conteúdo textual do Chemical Catechism, são divididos de forma que cada um trate especificamente de uma substância, uma classe de compostos ou reações, abrangendo 0 ar atmosférico, o calórico, a água, as terras, os álcalis, os ácidos, os sais, os combustíveis simples, os metais e os óxidos, a combustão, terminando o livro com um capítulo final sobre atração, repulsão e afinidade química (PARKES, 1807a).

O conteúdo textual do Chemical Catechism segue dois padrões diferentes de apresentação (Figura 4). A primeira parte se constitui de um texto mais curto e direto, formado de perguntas e respostas, enquanto a segunda parte consiste em longas notas de rodapé com informações adicionais (PARKES, 1807a). 
CHAPTER II.

OF ATMOSPHERIC AIR.

\author{
$W_{H A T}$ are the obvious properties* of atmosplecric \\ air? \\ Fluidity†, elasticity ${ }_{+}^{+}$expansibility, and gravity. \\ What do you mean by the elasticily of the air? \\ If atmospheric air be compressed $\S$ into a small
}

\begin{abstract}
- The habitable and cultivated parts of the earth are lavishly adorned with every thing to gratify the eye ; the diversified appearance communicates pleasure, and prevents satiety ; while the whole is surrounded by an atmosphere which preserves vegetable and animal life. It may be remarked, that to the transparency of this atmosphere we owe all the pleasure we receive from the variegated prospects which the earth affords.

t The fluidity of the air was considered in the last chapter. See pages 29. 33.

I If a bladder be tied up with a very small quantity of air within it, and put under the receiver of an air pump, it will be seen to inflate gradually as the pump is exhausted, till it becomes of its full size; owing to the elasticity of the small quantity of air within the bladder, which dilates in this manner, as the atmospheric pressure is removed. A wrinkled apple placed under the receiver of an air pump becomes plump and smooth, from the same cause. The elasticity of the air is such, that Mr. Boyle caused it to dilate by means of an air pump till it occupied nearly fourteen thousand times the space that it usually does.

The elasticity of the air is proved by carrying a bladder half full of air to the top of a high mountain; for the air will be perceived to expand gradually as it approaches the summit.

$\$$ Atmospheric air may be compressed into about the 128th of its usual volume; though if an apparatus could be procured of sufficient strength, it might doubtless be compressed to a much greater degree: but owing to its elastiçity it would regain its original bulk the instant the pressare was removed. Saussure made use of an instrument to show the elasticity of the air, which he called a manometer. It was a barometer enclosed in a well luted globe. Being thus enclosed, it was only sensible to the elasticity of the air within the globe. Berthollet's Clie- mical Statics.
\end{abstract}

Figura 4 - Dois padrões de texto - um com perguntas e respostas curtas, seguido das extensas notas de rodapé com informações adicionais (PARKES, 1807, p. 51).

A parte do texto alegadamente voltada aos aprendizes, a primeira parte, se limitava ao estilo catequético, consistindo de perguntas curtas e diretas e respostas igualmente curtas, na medida do possível. 
Como exemplo, apresentamos um trecho traduzido do capítulo VII do Chemical Catechism, sobre ácidos:

O que é um ácido?

A maioria dos ácidos são substâncias que produzem essa sensação na língua a qual chamamos de azedo; mas algumas substâncias são classificadas como ácidos e não possuem essa característica - apesar de possuírem algumas das outras propriedades dos ácidos.

Quais são as propriedades dos ácidos?

Ácidos mudam os sucos azul, verde e roxo dos vegetais para vermelho; e combinam com álcalis, terras ou óxidos metálicos, para formar esses compostos chamados sais.

Qual é a origem dos ácidos?

A maioria dos ácidos tem a sua origem na combinação de certas substâncias com o oxigênio, que tem sido chamado de princípio acidificante.

Como se sabe que o oxigênio concede acidez?

Isso foi construído por analogia; pois é observado que a maioria dos ácidos contém oxigênio, e que eles perdem a sua acidez exatamente na proporção da quantidade de oxigênio que lhes é tirado.

(PARKES, 1812, p. 170-172.)

As respostas, como se pode observar no trecho acima, começam por breves explicações introdutórias sobre o tema abordado, deixando ganchos soltos, para que deles sejam originadas novas perguntas que, por sua vez, também venham a deixar ganchos para a próxima pergunta a ser explorada. Dessa forma, o final da resposta de uma pergunta remete à pergunta seguinte, dando assim um encadeamento lógico à sequência do texto, tornando-o, de certa forma, mais fluido e objetivo (PARKES, 1812).

A segunda parte do texto, separada da primeira, consiste em notas de rodapé. Estas, diferente do texto principal, trazem parágrafos maiores e mais elaborados, que discorrem sobre os mais diversos assuntos - incluindo, por exemplo, experimentos propostos pelo autor, para que venham a ser realizados pelo tutor junto com o jovem aprendiz, ou mesmo detalhes de processos industriais envolvidos na obtenção de compostos citados no texto principal. Também nas notas 
de rodapé, o autor faz grandes exaltações à sabedoria e à bondade divinas, em alusão à teologia natural ${ }^{4}$, e tece comentários sobre a química da época, mencionando estudos e estudiosos contemporâneos a ele - na maior parte das vezes, autores filiados à "nova química" disseminada por Antoine Lavoisier (1743 1794) e seus colaboradores (PARKES, 1812).

Observa-se que o Chemical Catechism foi sendo continuamente atualizado com o passar das edições, incorporando as novidades, principalmente, nas notas de rodapé. No prefácio à quarta edição é dito que, devido ao sucesso do livro e aos comentários favoráveis que a obra havia recebido, o autor decidiu revisar e acrescentar detalhes, principalmente nas notas de rodapé, porque, segundo ele:

Uma vez que as interessantíssimas e verdadeiramente importantes recentes descobertas do Dr. Davy lançaram nova luz sobre muitos ramos da ciência química, foi necessário revisar cada parte das páginas seguintes com o maior cuidado, de modo a não perder nenhuma oportunidade de registrar os novos fatos e interpretações, para que o conjunto do texto e das notas possa ser acomodado à condição atual do conhecimento químico (PARKES, 1810, p. vii-viii).

As notas de rodapé oferecem não apenas uma referência sobre como a ciência se apresentava na época, mas também abrangem aspectos da história, cultura e até mesmo da moral vigente no começo do século XIX (PARKES, 1812, 1818).

De fato, a maior mudança que se pode observar é a ocorrida entre a primeira (1806) e a quarta (1810) edições do Chemical Catechism, na qual o autor ressalta que a quantidade de experimentos foi ampliada, que alguns capítulos passaram por um processo de revisão mais severo, muitas vezes sendo até mesmo reescritos, e que novos temas foram adicionados ao corpo do texto. Embora a sequência de capítulos tenha permanecido a mesma, as adições e modificações sofridas pelo

${ }^{4}$ A Teologia Natural é uma ramificação da teologia que faz uso do argumento teleológico, também chamado de argumento de finalidade, para inferir, por meio de observação e estudo da Natureza, a existência e a sabedoria de Deus. Uma referência sobre o assunto é Natural Theology, de William Paley (1743-1805), publicado em 1802, que se tornou um dos livros mais editados no século XIX (PALEY, 2006). Uma obra do início do século XIX, relacionando a química com a teologia natural, foi publicada em 1834 por William Prout (1785-1850) (SILVA, 2015). 
Chemical Catechism nessas primeiras edições avolumaram o texto e atualizaram a obra de acordo com a evolução do pensamento químico da época (PARKES, 1807a, 1812).

As notas de rodapé, no entanto, não possuíam caráter isolado do texto principal. No início da primeira nota de rodapé, Parkes explica o motivo por trás de sua proposta de separação do texto em dois segmentos. Para ele, a primeira parte era destinada ao jovem leitor, que deveria ler as perguntas e respostas sem interrupções, e poderia passar para as notas de rodapé após sua leitura completa, caso quisesse aprofundar-se no assunto proposto. As notas de rodapé também serviriam como guia ao tutor que o estivesse acompanhando, para que pudesse esclarecer as dúvidas que o jovem pupilo viesse a ter. Ao tutor também caberia guiar certos tipos de exposições demonstrativas. Desse modo, a memorização e compreensão total do texto seriam facilitadas, e não se atrapalharia a sequência lógica proposta no texto principal (PARKES, 1807a).

Para exemplificar a sistemática envolvida na escrita do texto principal e das notas de rodapé do Chemical Catechism, apresentamos a seguir uma sequência de perguntas e respostas acerca do ácido sulfúrico, presente no capítulo referente aos ácidos:

\section{O que é o ácido sulfúrico?}

O ácido sulfúrico é uma combinação de enxofre e oxigênio. Ele é comumente chamado de óleo de vitríolo*.

Como é obtido o ácido sulfúrico?

O ácido sulfúrico é obtido pela queima de enxofre em contato com oxigênio; por esse processo, o enxofre se combina com o oxigênio, e se torna acidificadoß.

Se o ácido sulfúrico é nada mais do que enxofre e oxigênio, o que ocasiona a sua fluidez?

O ácido sulfúrico, no instante de sua formação, está em um estado gasoso; porém os fabricantes acham necessário condensar esse gás por meio da água. Então o ácido sulfúrico comercial está sempre em um estado fluido+.

(PARKES, 1812, p. 176-177.)

Os caracteres especiais reproduzidos no trecho acima $\left({ }^{*}, \S,+\right)$ indicam as várias chamadas para as notas de rodapé presentes nessas páginas do Chemical 
Catechism. Como dito anteriormente, muitos são os tipos de informações que podem ser encontrados nas notas de rodapé. Para ilustrar essa pluralidade de informações, apresentamos o conteúdo das notas referentes ao exemplo do ácido sulfúrico:

\begin{abstract}
*Este ácido era extraído antigamente do vitríolo verde [sulfato de ferro]: daí o seu nome. Tem sido observado que o antigo nome óleo transmite uma ideia errônea da composição desse ácido, e que, por conta desse fato, ele [o nome óleo de vitríolo] deveria ser inteiramente descartado. Óleo é um composto de carbono e hidrogênio; mas o ácido sulfúrico não contém nenhuma destas substâncias(PARKES, 1812, p. 176). ${ }^{5}$
\end{abstract}

Nesse primeiro comentário, é possível observar o caráter informativo da nota de rodapé, na qual o autor acrescenta informações extras sobre a antiga forma de obtenção do ácido sulfúrico e sobre o nome que a ele era dado antes da adoção da nova nomenclatura da química desenvolvida pelo grupo de Lavoisier no final do século XVIII (LAVOISIER, 2007). Parkes ressalta, também, o motivo pelo qual o antigo nome deixou de ser usado, e acrescenta uma observação sobre a natureza dos óleos, diferenciando sua composição daquela do ácido sulfúrico. A segunda nota de rodapé, no entanto, possui um caráter completamente diferente:

$\S 0$ pupilo pode ser convencido de que o ácido sulfúrico é realmente produzido a partir da combustão de enxofre, pela queima de um pouco de enxofre em um frasco de vidro contendo gás oxigênio invertido sobre a água, conforme indicado na página 172. Ele pode verificar que o ácido sulfúrico foi realmente formado adicionando à água algumas gotas de uma solução de muriato de barita [cloreto de bário], da qual o ácido precipitará a barita (PARKES, 1812, p. 176).

Neste segundo exemplo de nota, Parkes sugere um experimento que pode ser realizado pelo tutor para simular um processo industrial ao pupilo, para que este

\footnotetext{
${ }^{5}$ Segundo Parkes (1810, p. 171), os ácidos são formados pela combinação de certas substâncias, o que ele depois especificou como substâncias que possuem alguma facilidade de entrar em combustão com o oxigênio, o qual ele chamou de "princípio acidificante". Devido a isso, segundo o conceito da época, o ácido sulfúrico não possuiria hidrogênio em sua composição, apenas enxofre e oxigênio - correspondendo, portanto, ao que hoje chamamos de "anidrido sulfúrico".
} 
seja "convencido" de que o processo descrito é realmente praticável. Já no terceiro exemplo, Parkes traz um aprofundamento de detalhes acerca do processo industrial, bem como informações específicas acerca da qualidade do ácido que se pode obter e como obter. Ele comenta, no final da nota, acerca de uma nova teoria sobre a formação do ácido sulfúrico, e onde se poderia encontrar essa teoria:

+Nas grandes fábricas para fazer ácido sulfúrico (as chamadas fábricas de óleo de vitríolo), o enxofre é misturado com 1/8 do seu peso de nitro [salitre] seco, e queimado em grandes câmaras de chumbo, de acordo com o projeto do Dr. Roebuck, a quem estamos em dívida por conta deste processo. O chão da câmara é coberto com água, para que o gás do ácido sulfúrico possa ser condensado assim que é formado. Uma quantidade indefinida de água é vertida para dentro da câmara; e quando o fabricante considera que ela está impregnada o suficiente, este ácido fraco é retirado, e concentrado por ebulição. Em seguida, é transferido para frascos de vidro, onde recebe um maior calor para extinguir uma porção adicional de água. Considera-se adequado para a venda quando é levado a uma gravidade específica [densidade] por volta de 1845. Mantendo-o em um frasco por um longo período de tempo, e em uma temperatura um pouco mais baixa, ele pode ser concentrado a uma gravidade específica de 2000; mas nunca é levado a essa gravidade para a venda comum. Uma nova teoria foi sugerida recentemente para a formação do ácido sulfúrico. Ver Nicholson's Journal de maio de 1807 (PARKES, 1812, p. 177).

Essas informações diversificadas, contidas nas notas de rodapé, muito agradaram alguns dos críticos da época. Em The Philosophical Magazine (ANÔNIMO, 1806, p. 76), o Chemical Catechism é descrito como "escrito de forma elegante e popular, e se revelou tão divertido quanto instrutivo", sendo a crítica encerrada com o comentário "[...] não duvidamos que o seu sucesso será correspondente aos seus méritos intrínsecos" (ANÔNIMO, 1806, p. 81). O periódico The Anti-Jacobin Review and Magazine comenta, sobre a obra de Parkes:

[...] mas se um tratado inteiramente introdutório for requerido, então não há hesitação em dizer que o Catechism é inequivocamente o trabalho mais 
apropriado, senão o único, projetado para introduzir os jovens ao conhecimento da filosofia química (ANÔNIMO, 1807a, p. 19).

O mesmo crítico chega a comentar que "nós desejaríamos que todos os nossos livros elementares possuíssem mérito igual, e fossem igualmente favoráveis aos princípios de virtude e verdadeira ciência" (ANÔNIMO, 1807a, p. 27). No entanto, nem todos os jornais se mostraram tão favoráveis ao estilo de escrita adotado por Parkes. Segundo The Monthly Review, um dos mais antigos jornais de críticas da época,

O formato de perguntas e respostas não é, em nossa opinião, aplicável a esses tópicos que consistem principalmente de fatos verdadeiros; e nós achamos que é ainda mais questionável quando, como no presente caso, as respostas possuem a intenção de serem memorizadas (ANÔNIMO, 1807b, p. 64).

Questionava-se, assim, a ideia de Parkes de que o formato catequético facilitaria a memorização do conteúdo, assim como a concepção de que a juventude exposta precocemente aos conceitos químicos teria sua "faculdade mental fortalecida" (ANÔNIMO, 1807b, p. 65), pois a teoria química moderna não seria, na opinião do crítico do Monthly Review, apreciada ou mesmo entendida por crianças. Considerando essas críticas formuladas contra o uso do formato catequético, uma parte do prefácio à segunda edição é dedicada à defesa do formato empregado na obra:

Pode-se também notar que a forma catequética, que foi primeiramente escolhida para este trabalho, possui pelo menos todas as vantagens que qualquer outro modo de instruir os jovens em química pode reivindicar; o trabalho já foi introduzido com vantagem em vários dos mais eminentes seminários do reino; e, se a intenção original do autor for seguida, a melhoria progressiva do estudante será agradável, rápida, e correta (PARKES, 1807a).

O prefácio à segunda edição afirma que o autor nunca esperou que as respostas e as perguntas fossem de fato memorizadas pelo pupilo palavra por 
palavra, e nem que a linguagem empregada nas questões e nas perguntas fosse adotada por completo pelo tutor ou pelo aprendiz. A intenção, segundo Parkes, era que essas informações e respostas prontas pudessem vir a ser compreendidas de forma clara pelo pupilo, para que este viesse a empregar sua própria linguagem nas respostas ao explicar suas ideias, ou ao responder por ele mesmo alguma das perguntas do Chemical Catechism. Dessa forma, o autor também se posiciona em relação ao comentário feito em The Monthly Review, que defende o uso de tratados elementares para uma melhor obtenção do conhecimento científico. Segundo a crítica desse periódico, tal abordagem condicionaria o pupilo a exercitar sua opinião e memória, ao expressar com suas próprias palavras o que foi aprendido pelos tratados com o auxílio do tutor (ANÔNIMO, 1807b; PARKES, 1807a).

Contudo, mesmo com uma crítica negativa no que concerne ao formato do livro e ao objetivo de sua escrita, The Monthly Review também reconhece algum mérito da obra de Parkes, elogiando o grande número de notas cheias de informações diversificadas e valiosas (ANÔNIMO, 1807b).

Em outra crítica não assinada, escrita para The Gentleman's Magazine, foi enfatizada a importância desse tipo de obra em uma nação industrial, salientando a relevância do conhecimento sobre a natureza e as propriedades das diferentes substâncias químicas por parte daqueles que trabalham com elas nas indústrias inglesas. Ao elogiar o conteúdo do Chemical Catechism e seus interessantes assuntos relacionados à química (ANÔNIMO, 1807c), o crítico se declara

\footnotetext{
particularmente satisfeito com a leitura do Chemical Catechism, que é planejado para proporcionar não só informação e diversão para o estudioso e o cavalheiro, mas, por meio de sua simplicidade e perspicácia, também dar instruções ao mecânico inquiridor e ao artesão ignorante (ANÔNIMO, 1807c, p. 144).
}

Tais críticas, a maioria em tom favorável, apontam para uma boa aceitação da obra de Samuel Parkes, e ajudam a entender o sucesso alcançado desde a sua primeira edição. Sua popularidade não ficou restrita ao Reino Unido, mas também pôde ser observada internacionalmente. O Chemical Catechism não foi apenas publicado em outros países de língua inglesa, como os Estados Unidos, mas também foi traduzido e publicado na França, Alemanha, Itália, Rússia e Espanha, 
tendo esta última até mesmo o adotado como livro didático em suas escolas e universidades (KURZER, 1997).

Outra evidência do sucesso do Chemical Catechism foi o surgimento de obras que o plagiavam ou buscavam imitá-lo. Um exemplo é o livro $A$ Grammar of Chemistry, lançado em 1809 e atribuído ao fictício Reverendo David Blair, que basicamente consistia no Chemical Catechism sem as notas de rodapé, com algumas paráfrases e textos modificados para que se adequasse ao estilo de uma gramática, não mais de um catecismo. Segundo relatos da época - em especial, o contido em A Biographical Dictionary of the Living Authors of Great Britain and Ireland, de 1816 - a aparição de A Grammar of Chemistry impulsionou Parkes a adaptar o Chemical Catechism para a forma de uma nova obra, que pudesse ser usada como livro didático, após denunciar e interromper a produção da versão plagiada de seu livro (BLAIR, 1822; WATKINS; SHOBERL; UPCOTT, 1816). O resultado recebeu o título de The Rudiments of Chemistry, e foi lançado em 1810, alcançando quatro edições. Esse livro consistia no texto principal do Chemical Catechism em forma de tópicos, e não de perguntas e respostas, com notas de rodapé consideravelmente reduzidas (KURZER, 1997; PARKES, 1826a).

Após os capítulos principais do Chemical Catechism, mais alguns complementos foram adicionados para concluir a obra com informações suplementares, como pode ser observado no sumário mostrado na Figura 3. Com o título de "notas adicionais", a primeira das seções complementares do livro é dedicada a pequenos ensaios sobre diferentes assuntos que foram mencionados ao longo do texto principal, mas que não tiveram lugar propício para serem desenvolvidos. Como exemplos, podemos citar os ensaios sobre: os efeitos da respiração, a neve, os usos do diamante, a dureza excessiva do gelo em alguns países, o efeito da água na vegetação, a cor do sangue, entre outros. Em seguida, uma seção é dedicada a tabelas químicas, entre as quais podemos citar, como exemplos, as tabelas que mostram: as quantidades de ácidos e bases necessárias para neutralizar umas às outras; a gravidade específica (densidade) de algumas substâncias mencionadas no livro; a temperatura de ebulição de diversas substâncias; entre outras tantas, com informações importantes para o aprofundamento do estudo da química, segundo a proposta do Chemical Catechism (PARKES, 1807a). 
A terceira seção complementar foi nomeada "Seletos experimentos instrutivos" na maior parte das edições. Nessa seção complementar, consta uma extensa lista de experimentos, cuja quantidade varia dependendo da edição analisada (PARKES, 1812, p. 510).

Por fim, a obra termina com uma seção dedicada a um vocabulário de termos químicos, um índice e, a partir da segunda edição, um índice das novas adições ao texto original (PARKES, 1807a).

A questão experimental no Chemical Catechism é um assunto muito destacado desde sua primeira edição. $\mathrm{Na}$ folha de rosto da segunda edição já se chama a atenção para a presença de experimentos na obra. Da mesma forma, as folhas de rosto das edições posteriores também destacam o fato da obra incluir um grande número de experimentos, como pode ser observado na Figura 1 e na Figura 2 (PARKES, 1807b, 1812, 1818, 1834). Assim, considerando a importância da experimentação no Chemical Catechism, esse aspecto será discutido com maior profundidade no capítulo a seguir. 


\section{Capítulo III: Os experimentos e demonstrações químicas no Chemical Catechism.}

\subsection{As ilustrações: em busca do melhor laboratório}

Sendo um químico de preparações por profissão, Parkes enfatizava o uso de experimentos pelos jovens para o aprimoramento de seu conhecimento químico. Segundo ele, "nada tende a gravar tantos fatos químicos na mente quanto a exibição de experimentos interessantes" (PARKES, 1807a). Para tanto, o Chemical Catechism contava com figuras ilustrativas de aparelhagens de laboratório, bem como descrições acerca de cada uma das representações dos utensílios químicos.

Nas três primeiras edições do Chemical Catechism, as gravuras de instrumentos de laboratório foram feitas por meio de chapas de vidro gravadas com ácido fluorídrico - uma curiosidade que o autor faz questão de destacar tanto nas gravuras em si (Figura 5 e Figura 7) quanto na descrição dos aparatos ilustrados (Figura 6 e Figura 8), pois não se tratava de uma técnica usual ${ }^{6}$. Segundo Parkes, embora tenha sido muito difícil produzir uma chapa de vidro que suportasse o peso do rolo de impressão, depois de muitas falhas e frustrações, o resultado final o deixou satisfeito - pois não era apenas uma demonstração física do que a perseverança pode conquistar, mas também era um exemplo perfeito para apresentar ao estudante o poder do ácido fluorídrico (PARKES, 1807b, 1807a, 1808).

\footnotetext{
${ }^{6}$ As técnicas de gravura mais usadas na época incluíam o uso de chapas de metal (gravura a água forte) ou placas de madeira (litogravura).
} 


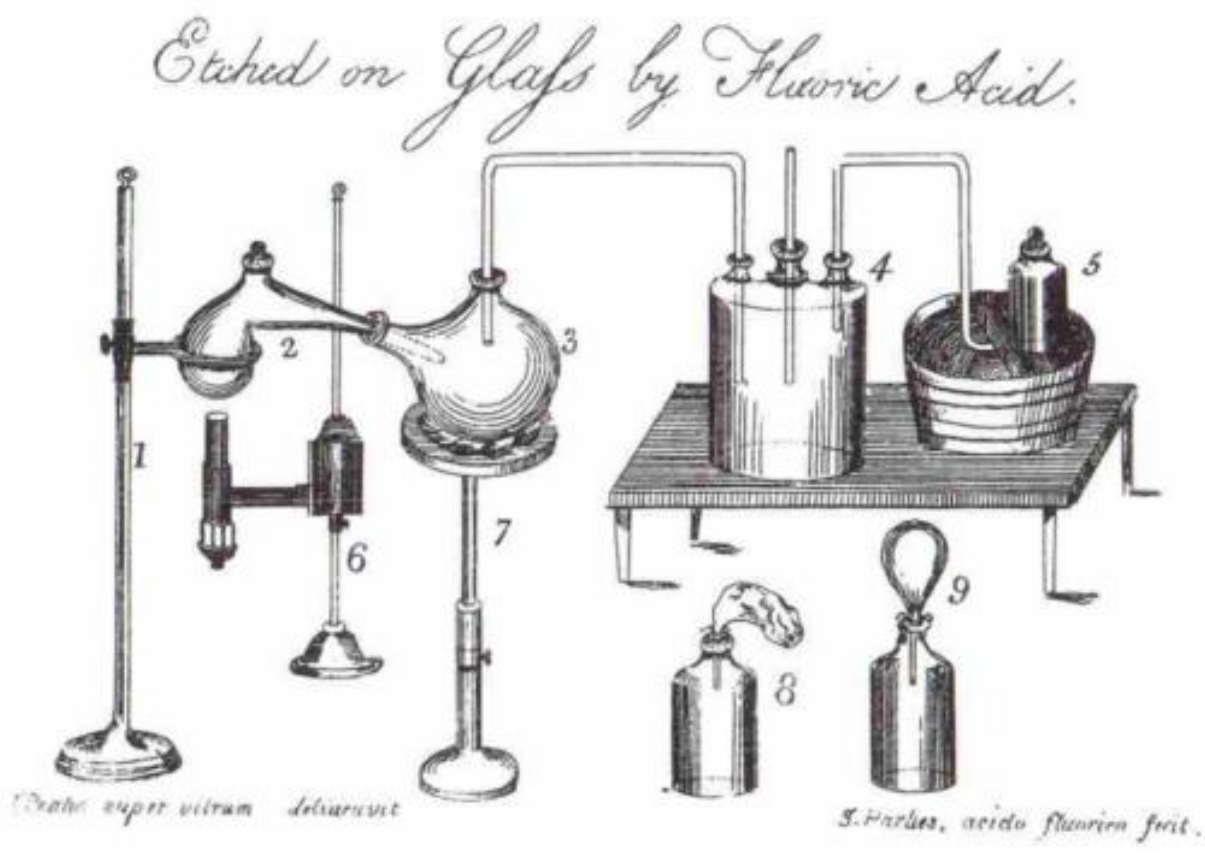

Figura 5 - Gravura de aparatos químicos da primeira edição do Chemical Catechism, produzida com o uso de uma placa de vidro e ácido fluorídrico (PARKES, 1807b). 


\section{TRONTTSPIECE, Elclad on a Pome of Glass by Fworie Aatd.}

As it was imagined that great advantage might arive to the arts, if engravings coald bo taken from a pane of glaw with the ane fecility as irom a sbeet of copper, the author was indeced to molko the attempt. After veveral failures and dieoppointments, be at length, with the advice and aesiotance of an in. xenious friend, discorered a method of guarding the glass 20 as to enable it to endure the rolling-prest without injury, and tho froetinplece, though not a finibbed drawing. in given as - specimen of this new mode of printing. It reprevents'a simple portable apparatus very usefal for a variety of purposes of distillation and analysis, and cay be thus described :

No. 1. The stand with its moveable ring, to support a retort, a oil ank, or evaporating diah.

2. A tubalated glass retart.

3. The glass receion, with two tubalures, for the collection of the fint products of distillation.

4. A glaw jar, with throe necks, for receiving that part of the prodect which may not condense in the first receiver.

5. A glase ressel, standing upon the shelf of a poeumatic trough. for the purpose of receiving any incondensuble gas that may ariue. By removing the groond stopper, and odopting the blader-receiver, described in note. page 538, to its neck, the cas cau readily be decanted, and removed as occasion may require.

6. An Argand's lamp for beating the retort, so contrived that it may be elevatcd or lowered at pleavure.-Cuntrary to the general practice, which fixes the lamp upon the some ot and as the retort, it is here placed separotely. The conveniency of this mast be evident to every practical man; for the lamp may not only be removed when the procest is going on too rapidly, but, when the operation is finished, may be entirely withdrawn, and emploged for any other purpose, while the apparatuo io cooling.

7. The otand with its cuabion, to support the receiver.

0. The botelo with the Uledder-receiver, as mentioned at prge 538.

9. The same receiver, at it is oopponed to oppers when cistesded by gav.

Figura 6 - Descrição dos aparatos químicos ilustrados na Figura 5 (PARKES, 1807b). 


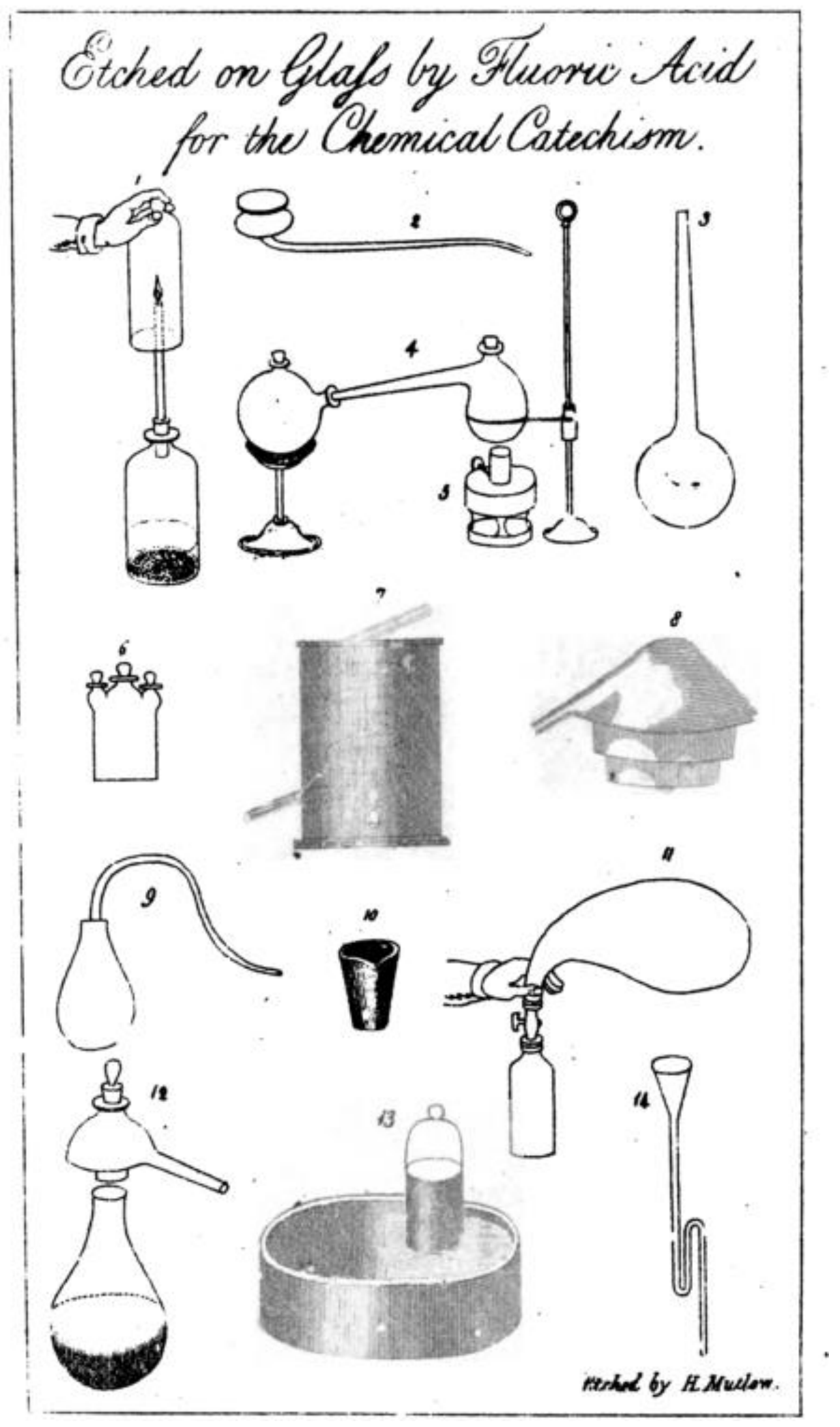

Figura 7 - Gravura de aparatos químicos da segunda e terceira edições doChemical Catechism, produzida com o uso de uma placa de vidro e ácido fluorídrico (PARKES, 1807a, 1808). 


\section{FRONTISPIECE, \\ now Ax \\ ETCHING ON GLASS, \\ By means of Flweric Acid.}

F10. 1. Represents a glass jar, inverted over the flame isming from the combtation of hydrogen gas. In this case the oxygen of the atmosphere combines with the hydrogen, and water is formed; which will évidently appear attached to the. invide of the jot. The undermost vessel is to contain a mixture of the fitings of the or iton, with some sulphuric acid diluted with mix- times' it weight of water, and a glass tube, or a piece of tobacco-pipe, thrust- through a petforated cork, fixed into its neck:

Fyo. 2. A glags funhel for pouring acids and other liquids, in a hotisontal direction, into retorts and other vessels.

Fic. 3. A glas'matrass. In a great variety of experiments nothing, howewer, answers better than a common oil-flask.

F10, 4. Corisists of a distilling spparatus. The retort and its receiver,are placed each on its proper stand; the retort has an opening on its top with a stopper to fit ; and its branch or mooth is inclined a little, so as to enter the receiver, to which it. is to be luted.

Fio. 5. An Argand's lamp. This is placed imniediately under the retort, and, thongh contrary to gentral practice, should alwnys be separated,' and not' slide upon the stem of the retortstand, in order that it may be rendily trimmed, removed, lowered or raised, without disturbing the apparatus.

Fic. 6: A tubulated botele. This is very commodious for seviral purposes, but principally to be connected by bent tubes to the tubulare of the receiver (Fig. 4.) ; so that by employing two or more of these, a Woulfe's apparatus may be formed.

Fia. 7. A refrigeratory, in which a metallic tube or worm is fixed, so that the vapours arising in distillations may pass into the tube at its upper end, and be coodecoed in their yassage by the cold water, which surrounds this tube. A refrigeratory is generally made of wood or, particularly when small," of japauned tin.

Figura 8 - Descrição dos aparatos químicos ilustrados na Figura 7 (PARKES, 1807a, 1808).

Da quarta edição do Chemical Catechism em diante, as gravuras produzidas com a técnica do ácido fluorídrico foram substituídas por ilustrações do laboratório da Surrey Institution, em Black Friars Bridge, Londres (Figura 9). Essa instituição foi fundada em 1808 nos moldes da Royal Institution, por meio da ação conjunta de proeminentes comerciantes, banqueiros e industriais da cidade de Londres, que contribuíram financeiramente para o seu estabelecimento (KURZER, 2000). 


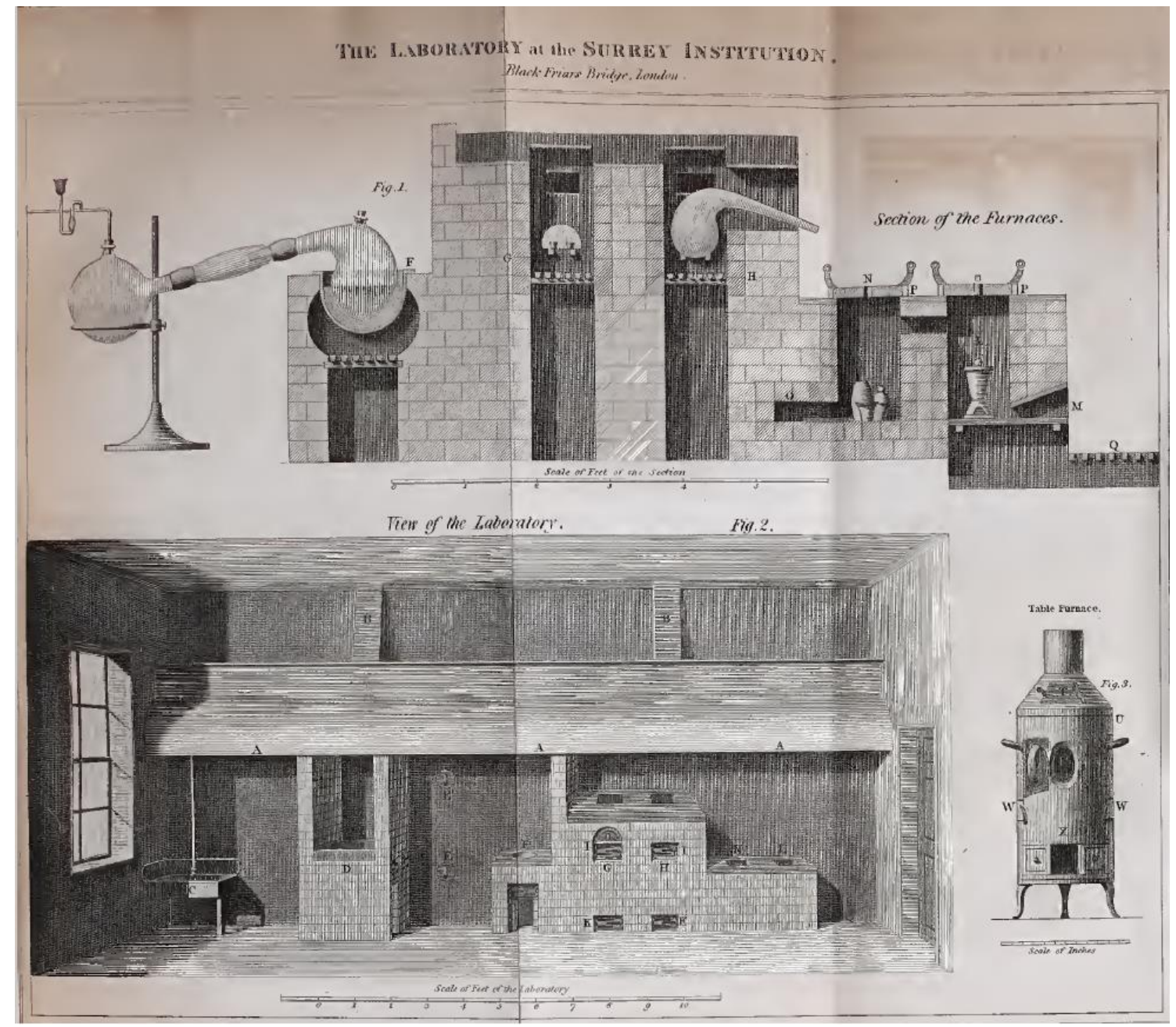

Figura 9 - Ilustração do laboratório da Surrey Institution (PARKES, 1819)

De acordo com Kurzer (2000), a Royal Institution, de início, contava com grande presença de proprietários de terras em seu conselho administrativo, o que favorecia os interesses agrícolas em detrimento dos interesses mercantis. Enquanto os proprietários de terras se interessavam mais por atividades que envolvessem, por exemplo, o aperfeiçoamento da fertilização do solo, a melhora do plantio, ou mesmo a detecção e exploração de possíveis depósitos minerais de suas propriedades para fins econômicos, os comerciantes se interessavam, por exemplo, em saber quais produtos estrangeiros eventualmente proveriam maiores rendimentos em transações comerciais (CUTLER, 1976; KURZER, 2000).

Como exemplo de favorecimento dos interesses agrícolas na Royal Institution, podemos citar o curso anual ministrado por Davy sobre química agrícola entre os anos de 1800 e 1812, no qual ele enfatizava o emprego da ciência na gestão do solo para a melhoria do cultivo e da colheita. A Surrey Institution, então, nasceu com o 
objetivo de atender demandas mais especificamente ligadas ao comércio. A Surrey Institution era dirigida por um corpo administrativo de interesse majoritariamente mercantil que, além de representar melhor e enfatizar as preocupações comerciais e manufatureiras de seus idealizadores, também viria a servir como espaço para atividades educacionais, culturais e sociais para os seus integrantes e colaboradores (KURZER, 2000).

Segundo o The New Monthly Magazine (ANÔNIMO, 1823a, p. 15), a Surrey Institution era uma das quatro principais instituições londrinas da época no que concernia à disseminação do conhecimento científico, técnico e literário, juntamente com a Royal Institution, London Institution e Russell Institution.

A Surrey Institution operou por um total de quinze anos, fechando suas portas em março de 1823 após sucessivas tentativas de sanear sua situação financeira, que frequentemente apresentava despesas superiores à soma dos seus rendimentos. Por ocasião da última aula ofertada pela instituição, Charles Woodward ${ }^{7}$ (1789-1877) exprimiu seu pesar pelo fechamento ao final de sua palestra (KURZER, 2000):

A ideia de que, nesta noite, as portas desta Instituição serão fechadas deve ser uma questão de profundo pesar para todos os amantes da ciência [...] mas o nome da Instituição viverá e florescerá quando suas paredes mofarem e se deteriorarem, e não deixando um escombro sequer para trás (ANÔNIMO, 1823b, p. 528).

Algumas instalações que contribuíram para seu lugar de destaque na metrópole inglesa foram a sua biblioteca, que possuía um extenso acervo de livros das mais diversas áreas de conhecimento, de religião e teologia a literatura popular e filosofia natural; sala de conversação; sala de leitura, que era frequentemente abastecida com jornais e periódicos; a "Rotunda", um espaço circular que

${ }^{7}$ Charles Woodward foi um físico membro da Royal Society que no começo de sua carreira estudou com Michael Faraday e deu algumas palestras de química. Mais tarde, ele foi um dos fundadores da Islington Literary and Scientific Institution and Scientific Society,instituída em 1837, da qual posteriormente foi presidente. Em 25 de janeiro de 1839, Woodward deu uma palestra sobre a polarização da luz na Royal Institution, que foi assistida por cerca de 300 pessoas. Ficou conhecido pelo seu trabalho com a luz polarizada, tendo sido o autor de A Familiar Introduction to the Study of Polarized Light, with a description of, and Instructions for using, the Table and Hydro-Oxygen Polariscope and Microscope, que teve sua primeira edição em 1848 e três edições no total (ANÔNIMO, 1877; KURZER, 2000; SIEGEL, 2017). 
desempenhava o papel de auditório para palestras geralmente sobre ciências, como química, filosofia natural e ciências da vida, mas também de outras áreas, como arquitetura, artes, literatura e música, sempre ministradas por reconhecidos conhecedores dos seus respectivos campos; e um laboratório, um atributo particular do qual a instituição parecia se orgulhar muito em ter, e que Parkes tomou como exemplo para ilustrar sua obra (KURZER, 2000).

No Chemical Catechism, Parkes comenta que decidiu utilizar a ilustração do laboratório da Surrey Institution por considerá-lo o mais avançado do reino em sua época. Segundo ele, a representação por meio de gravuras possibilitaria que qualquer pessoa que desejasse um laboratório próprio poderia vir a construir um estabelecimento semelhante àquele de acordo com a ilustração fornecida. Na nona edição do Chemical Catechism, não apenas a representação do laboratório da Surrey Institution foi apresentada antes dos primeiros capítulos, mas também foi adicionada uma gravura com alguns aparatos químicos (Figura 10), com o intuito de familiarizar o leitor com tais equipamentos, necessários à execução dos experimentos propostos no livro (PARKES, 1810, 1812, 1819). 

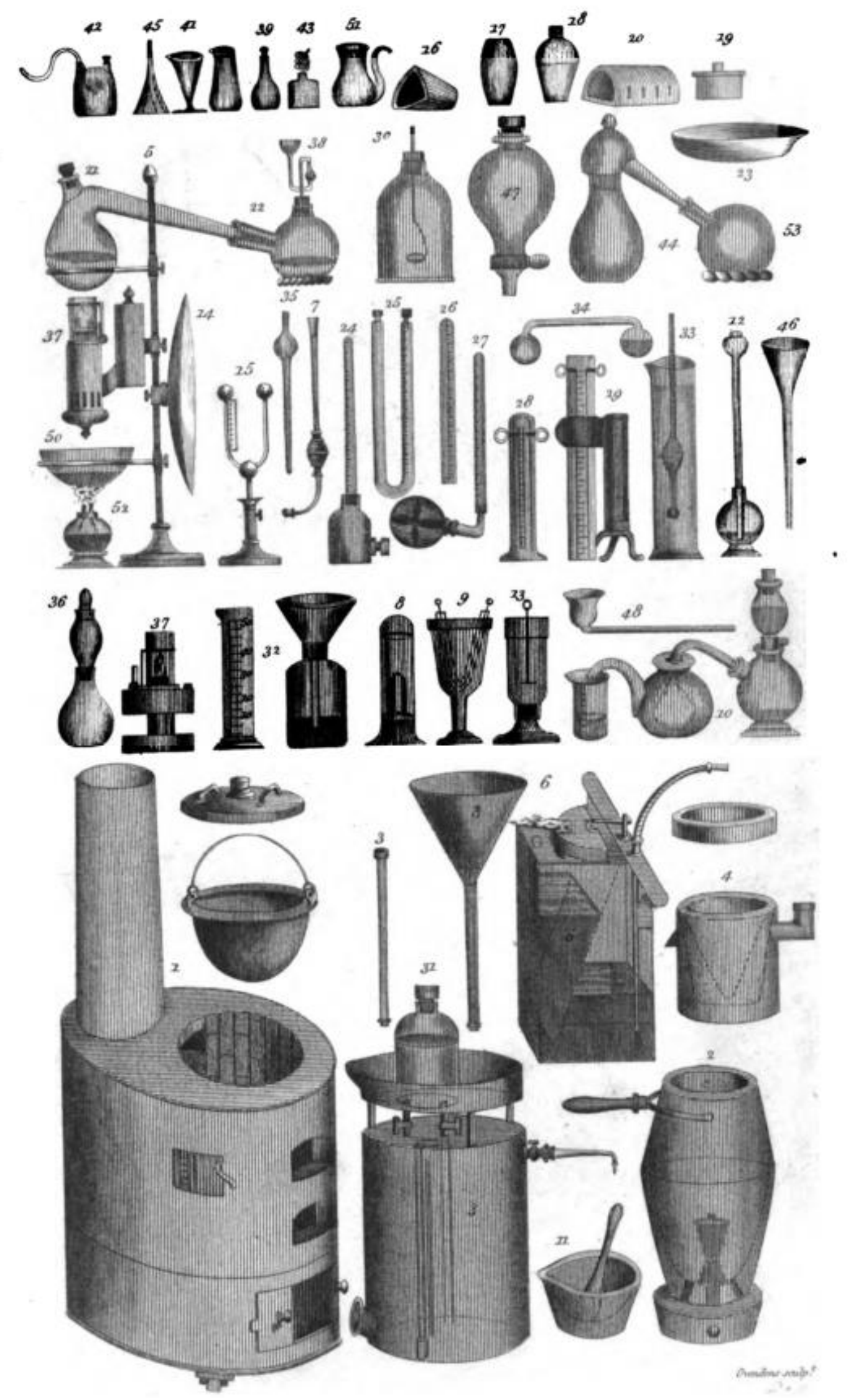
Figura 10 - Gravura de aparatos de laboratório, adicionada a partir da nona edição do Chemical Catechism (PARKES, 1819).

Na décima edição, lançada em 1822, o laboratório da Surrey Institution foi substituído pela ilustração de uma instalação que se julgou ainda mais elaborada, a da London Institution de Moorfields (Figura 11).

A London Institution foi estabelecida em 1805 com motivações semelhantes às da Surrey Institution: como uma instituição voltada para os interesses comerciais, mais do que os agrícolas, o que se evidencia nos estudos de Cutler (1976, p. 8) sobre os proprietários da instituição. De um total de 47 proprietários, 28 possuíam ligações diretas com o comércio, ou seja, cerca de $60 \%$ do total, sendo que 5 dentre os demais proprietários foram enquadrados no que ele chamou de "não classificado ou sem informação", e os restantes eram médicos, cirurgiões, advogados, e indivíduos que possuíam ocupações científicas ou de interesses científicos diversos.

Por treze anos a London Institution funcionou em instalações temporárias, em propriedades que não eram consideradas suficientemente apropriadas para suas atividades. Salas apertadas e com pouca iluminação, falta de espaços propícios para palestras e encontros administrativos, organizações arquitetônicas inconvenientes, instalações de difícil acesso por meio de carruagens e custos elevados eram apenas alguns problemas que os administradores encontraram nas primeiras sedes. Em 1815, uma propriedade em Moorfields foi negociada, na qual o edifício que viria a hospedar a instituição deveria ser construído. Foi feito um anúncio convidando arquitetos a enviarem projetos a serem avaliados, sendo oferecida a quantia de cem guinéus como prêmio para a melhor proposta (CUTLER, 1976).

Após uma série de imprevistos, entre eles a necessidade de reduzir os custos da construção e a natureza instável do solo de Moorfields, que exigiu suportes ampliados e mais profundos para as fundações do edifício, no dia 9 de julho de 1818 a biblioteca da nova London Institution estava enfim pronta para receber os primeiros livros em suas prateleiras. Porém, a finalização do edifício aconteceu apenas alguns meses depois, em 21 de abril de 1819, quando a nova sede enfim abriu suas portas pela primeira vez ao público (CUTLER, 1976; LONDON INSTITUTION, 1835).

Os ambientes do novo edifício da London Institution incluíam: duas salas de leitura, uma para jornais e outra para panfletos e periódicos; uma sala de reuniões; 
uma sala para instrumentos ópticos e astronômicos; um salão principal; um octógono, que dava acesso ao auditório construído tendo o da Royal Institution como modelo, e no qual eram realizadas palestras para até 700 pessoas; uma biblioteca, que ocupava por completo o primeiro andar; e um laboratório, juntamente com uma sala de aparelhagens, que ficavam por detrás do auditório.

A substituição da ilustração do laboratório da Surrey Institution pelo laboratório da London Institution, como modelo oferecido aos leitores, ocorreu entre a nona e a décima edição do Chemical Catechism, exatamente no período em que a London Institution foi estabelecida em Moorfields. Isso mostra a preocupação de Parkes em manter-se atualizado com o que ocorria na Inglaterra e seu compromisso de trazer tais atualizações aos seus leitores, assim como sua preocupação em evidenciar a necessidade de laboratórios completos e sofisticados, valorizando simultaneamente a importância do trabalho experimental. A gravura de aparatos de laboratório (Figura 10), contudo, se manteve a mesma desde a edição de 1819 até a edição de 1834, sendo deixada de lado apenas nas reedições de William Barker de 1837 e 1854, que não contaram com qualquer gravura (PARKES, 1819, 1822, 1834, $1837,1854)$. 


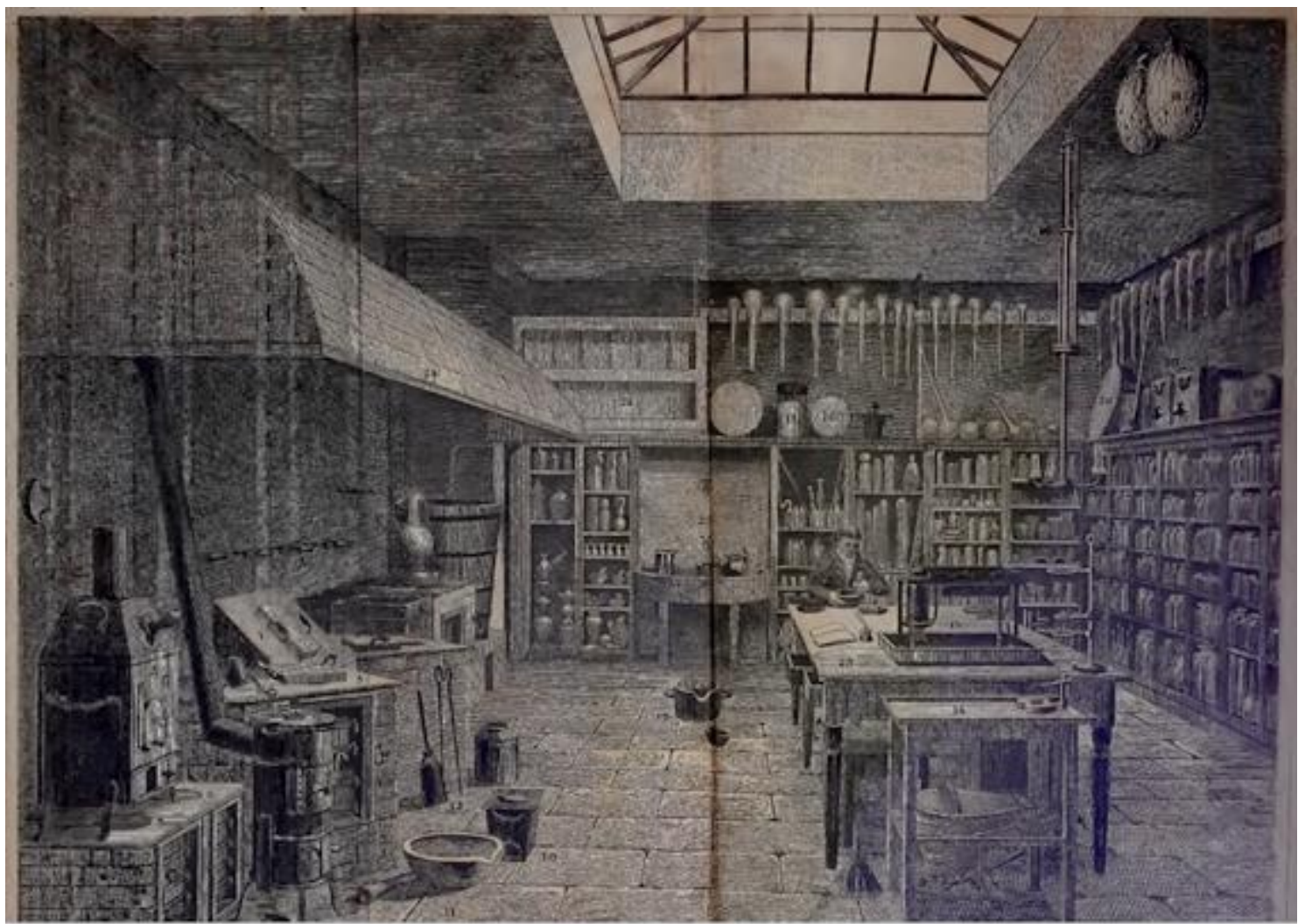

Figura 11 - Ilustração do laboratório da London Institution de Moorfields (PARKES, 1822).

\subsection{A química ad oculi: os experimentos no Chemical Catechism}

Os experimentos sugeridos por Parkes no Chemical Catechism podem ser encontrados em duas partes distintas da obra. A parte principal do texto, a parte catequética, pelo seu próprio formato de perguntas e respostas, não era dimensionada para a proposição de experimentos, embora nela existam algumas rápidas menções a eles. Nas notas de rodapé, por sua vez, os experimentos encontram o primeiro dos espaços para sua proposição e descrição. O segundo espaço é a seção adicional ao final da obra, intitulada "Seletos experimentos instrutivos", que se constitui em um capítulo inteiro dedicado apenas a sugestões de experimentos e demonstrações químicas (PARKES, 1812).

\subsubsection{Os experimentos nas notas de rodapé}

Os experimentos apresentados nas notas de rodapé podem ser classificados em três categorias, conforme seus diferentes objetivos. A primeira categoria abrange o objetivo de articular o texto principal com algum experimento comprobatório, de 
modo que o experimento viria a validar as afirmações científicas apresentadas no texto. Ou seja, esses experimentos foram propostos sob uma perspectiva dogmática: Parkes os apresenta como uma forma segura de se alcançar as verdades presentes na Natureza, pois, segundo ele, a racionalização da investigação e do experimento levaria a jovem mente para longe do sofisma, fanatismo e superstição, que poderiam enganar a mente não preparada (PARKES, 1812).

Como exemplo, destacamos a forma como Parkes propõe um experimento após afirmar que as substâncias líquidas são substâncias sólidas que foram convertidas em líquido pelo calor:

O seguinte experimento irá provar que é o calórico o que converte sólidos em fluidos: - Exponha uma libra de água e uma libra de gelo, ambos a $32^{\circ}$ [F], em uma sala em que a temperatura esteja acima do ponto de congelamento. A água chegará à temperatura da sala várias horas antes do derretimento do gelo. O calórico, portanto, que tem entrado todo o tempo no gelo, mas que não foi verificado pelo termômetro, deve ter se combinado quimicamente com ele para dar fluidez (PARKES, 1812, p. 29, grifos no original).

O grifo feito por Parkes na palavra "provar", juntamente com a escolha de algumas expressões ao introduzir seus experimentos nas notas de rodapé - tais como: "o funcionamento deste princípio pode ser evidenciado pela seguinte experiência" (PARKES, 1812, p. 41); "pode ser demonstrado por um experimento simples"(PARKES, 1812, p. 46); "isso pode ser evidenciado pelos seguintes experimentos impressionantes" (PARKES, 1812, p. 84); "para se convencer de que" (PARKES, 1812, p. 85); e "pode ser verificado pelo seguinte experimento"(PARKES, 1812, p. 93) - nos mostram que Parkes divulgava uma visão de ciência na qual a experimentação teria papel de validação. Nesses experimentos, a prática seria um meio de comprovar a teoria que fora anteriormente apresentada ao aprendiz (PARKES, 1812).

Em sua maioria, esses experimentos apresentavam, em especial, um grande apelo visual. A constatação do resultado do experimento partiria da observação e contemplação do aluno, que na maioria das vezes o observaria ser executado pelo 
tutor (PARKES, 1812). O seguinte exemplo mostra um desses experimentos de forte apelo visual, destinado a ilustrar a combustão, uma das propriedades do gás oxigênio:

A necessidade de oxigênio para auxiliar a combustão pode ser demonstrada pela seguinte experiência simples: Despeje um pouco de água em um prato plano, coloque duas ou três velas de cera acesas de diferentes comprimentos na água, e inverta um jarro de vidro alto sobre elas. As chamas das diferentes velas logo serão vistas como cada vez menores, e, por fim, serão apagadas em sucessão. Aquela que estiver mais alta será a primeira a ser apagada, e a mais curta será a última, devido ao ar mais puro que ocupa a parte inferior da jarra (PARKES, 1812, p. 58).

Pode-se observar, nesse exemplo, que não apenas são dadas as instruções para a execução do experimento, mas também é introduzida uma breve explicação sobre o motivo de uma das velas se apagar mais rapidamente do que a outra, em função de seus tamanhos diferentes. Outro exemplo pode ser encontrado no capítulo sobre o calórico:

Coloque um pouco de éter em uma pequena retorta, prenda uma bexiga ao bico dela e segure a retorta sobre uma lamparina. O éter ferverá rapidamente, e o gás que surgirá dele logo irá ocupar a bexiga e distendêla ao seu tamanho completo. Se a bexiga for então mantida dentro d'água, o gás será condensado pela perda do calor e a bexiga entrará em colapso. Para que esta experiência tenha sucesso, é necessário aquecer previamente a bexiga a 80 ou 90 graus $[\mathrm{F}]$, para evitar que o gás seja condensado em primeira instância (PARKES, 1812, p. 87).

Nesse exemplo, Parkes utiliza instrumentos simples, como uma bexiga de algum animal, uma retorta, um pouco de éter, água e uma lamparina, para propor um experimento prático que demonstra a expansão dos corpos voláteis pelo calor, e fornece detalhes importantes para que a demonstração seja bem sucedida em sua execução (PARKES, 1812). 
Embora o apelo visual se fizesse mais presente nesse tipo de proposta, na qual as demonstrações relacionavam a prática com um conceito apresentado, não era o único tipo de apelo sensorial explorado por Parkes nas notas de rodapé. Há também, em alguns experimentos, o apelo ao olfato, como no experimento em que se propõe a produção de amônia (PARKES, 1812):

Pelo seguinte processo amônia pode ser formada, de modo a tornar-se evidente aos sentidos em pouco tempo. Pegue algumas limalhas de estanho ou zinco, despeje sobre eles um ácido nitroso moderadamente diluído. Depois de um curto período de tempo adicione na mistura um pouco de cal viva, ou um álcali cáustico, e um cheiro fortemente pungente de amônia será produzido (PARKES, 1812, p. 162).

O apelo sensorial representava não apenas para Parkes, mas para grande parte dos divulgadores de ciências da época, um poderoso trunfo para maravilhar o público, incitando por meio de explosões, cores, odores e luzes uma grande curiosidade pelos fenômenos científicos que, por conseguinte, atrairia a atenção do público e motivaria a procura pela ciência. Dessa forma, o contato com a química proporcionado pelos arrebatadores experimentos tornava a experiência entusiasmante e suscitava grande interesse e curiosidade, tanto nos expectadores das palestras e demonstrações químicas, quanto nos leitores dos livros introdutórios à química (BALDINATO, 2015; KNIGHT, 2006).

A segunda categoria de experimentos propostos no Chemical Catechism se caracteriza pelo objetivo de ensinar algum aspecto da metodologia científica, técnicas gerais, tal como um teste para análise dos componentes de uma mistura, ou mesmo uma operação comumente usada na química. Esta categoria abrange menos experimentos do que as demais, apresentando poucas ocorrências no decorrer da obra. Como exemplo, destacamos a descrição e proposta de um experimento de cristalização, presente no capítulo dedicado aos sais (PARKES, 1812): 
Pegue uma porção de sulfato de soda (sal de Glauber) [sulfato de sódio hidratado] e seque-o sobre um fogo comum, o que o reduzirá para menos da metade do seu peso. Dissolva este sal seco em três vezes o seu peso de água fervente, coloque a solução de lado e, quando frio, bonitos cristais que se assemelham aos cristais originais serão encontrados na solução. Ao examinar atentamente a solução, se poderá observar os cristais se formando enquanto a solução esfria. Este é um experimento barato e fácil, e pode ser mostrado ao aluno como um exemplo de cristalização em geral (PARKES, 1812, p. 237).

A terceira categoria de experimentos que encontramos nas notas de rodapé do Chemical Catechism abrange o objetivo de ensinar ao tutor e ao pupilo como produzir alguns dos compostos mencionados no texto principal, ou mesmo como obter alguns dos compostos que seriam necessários para a execução de outros experimentos propostos no decorrer da obra. Diferentemente das demonstrações incluídas nas categorias anteriores, tais experimentos não pretendiam apelar aos sentidos do pupilo ou do tutor, nem comprovar um conceito, mas apenas produzir algo (PARKES, 1812). Como exemplo, podemos citar o detalhamento de como obter gás cloro para uso experimental, no rodapé do capítulo sobre ácidos:

O gás ácido oximuriático [gás cloro] pode ser obtido para experiências químicas pelo seguinte método: Coloque em uma retorta um pouco de óxido preto de manganês em pó; e despeje sobre ele o dobro de seu peso em ácido muriático [ácido clorídrico] forte; conecte a retorta com a cuba pneumática, e receba o gás sobre a água. Quando a ascensão do gás abrandar, aplique o calor de uma lamparina, e ele será liberado em abundância (PARKES, 1812, p. 183-184). ${ }^{8}$

\footnotetext{
${ }^{8} \mathrm{O}$ ácido clorídrico é corrosivo e pode causar riscos para a saúde quando inalado ou quando em contato com qualquer tecido vivo. Mais do que isso, o cloro, na época chamado ácido oximuriático, quando em contato com a pele ou com os olhos, pode causar graves queimaduras e graves irritações (NATIONAL OCEANIC AND ATMOSPHERIC ADMINISTRATION, 1999a, 1999b; RUSSELL, 2001).
} 
No entanto, apesar da periculosidade no manuseio de tais substâncias, Parkes não apenas ensina como obtê-las, mas também indica vários experimentos que exigem sua manipulação. Outro exemplo de obtenção de uma substância perigosa se faz presente no capítulo sobre o hidrogênio, no qual Parkes ensina, por meio de um experimento, como obter sulfeto de hidrogênio gasoso:

Para obter gás hidrogênio sulfuretado [sulfeto de hidrogênio], derreta em um cadinho três partes em peso de limalhas de ferro e uma parte de enxofre; reduza a massa a pó e coloque-a com um pouco de água em uma vasilha de vidro com duas bocas: vede uma dessas bocas com a extremidade de um tubo de vidro recurvado e deixe a outra extremidade do tubo passar por baixo de uma jarra de vidro em uma cuba pneumática, o jarro estando invertido e cheio de água. Em seguida, despeje ácido muriático [ácido clorídrico] diluído através da outra boca do recipiente, que deve ser imediatamente fechada. $\mathrm{O}$ gás hidrogênio sulfuretado será agora liberado em abundância e fluirá para o frasco de vidro, deslocando a água (PARKES, 1812, p. 253-254).

Além da descrição aparentemente despreocupada sobre como obter substâncias perigosas, Parkes também sugere vários experimentos de efeito explosivo, com o objetivo de maravilhar os aprendizes, resultando muitas vezes em substâncias tóxicas como produtos. Ademais, muitos de seus experimentos envolviam substâncias perigosas em sua execução, como clorato de potássio, fósforo, mercúrio e gás amoníaco (PARKES, 1812).

Devido a isso, uma das maiores críticas que Parkes recebeu nos periódicos da época foi exatamente acerca da periculosidade de alguns dos seus experimentos, que certamente não eram recomendáveis para iniciantes, muito menos para os jovens. Segundo The Monthly Review:

Os 'experimentos instrutivos selecionados' [...] formam uma valiosa adição ao livro, e são escolhidos criteriosamente. A única objeção que devemos 
fazer a eles é que vários deles parecem de natureza perigosa. Desejando, provavelmente, estimular a curiosidade tanto quanto possível, o Sr. Parkes introduziu com frequência substâncias explosivas ou detonantes, cuja gestão requer o maior cuidado, e a destreza mais experiente. Não devemos considerar seguro para um iniciante em química, mesmo de idade avançada, repetir todos os processos descritos pelo Sr. Parkes; muito menos confiamos em substâncias como o fósforo e o pó fulminante ${ }^{9}$ nas mãos de jovens (ANÔNIMO, 1807b, p. 66).

No entanto, Parkes não é de todo incauto. Em alguns experimentos selecionados, ele dá avisos de segurança e sugere formas da demonstração ser feita de maneira mais cautelosa. Como exemplo, podemos citar uma das experiências presentes no capítulo sobre combustão:

Se uma onça de ácido nitroso forte for misturada com cerca de metade do seu peso de ácido sulfúrico concentrado, e derramado em um pouco de óleo de terebintina, o todo entrará em chamas imediatamente. Neste experimento é o oxigênio do ácido nítrico que produz a combustão. $O$ frasco de onde o ácido misto é derramado deve ser amarrado na extremidade de um longo bastão para preservar o operador de ser ferido pelo borrifo dos materiais (PARKES, 1812, p. 379 grifo no original).

O aviso, claramente, busca proteger o operador do experimento, provavelmente o tutor, de uma possível projeção de reagentes em função da violência da reação química. No entanto, em que pese essa advertência, a demonstração não deixa de ser altamente perigosa e possivelmente desastrosa. Ademais, avisos como esses nos experimentos do Chemical Catechism são muito menos frequentes do que o desejado ou mesmo necessário. Por vezes, a periculosidade dos experimentos é indicada pelo reconhecimento dos riscos, mas não por um aviso explícito.

${ }^{9} \mathrm{O}$ "pó fulminante" (fulminating powder), um explosivo, consiste em uma mistura de salitre, carbonato de potássio e enxofre (URE, 1821, v.2, s.v.). 
Como exemplo, podemos apontar um trecho do capítulo sobre metais, no qual Parkes indica a combustão do arsênio metálico como exemplo de experimento impressionante: "Se o arsênio metálico for previamente inflamado em oxigênio, ele queimará até que seja completamente consumido. A combustão é muito brilhante e constitui um experimento impressionante" (1812, p. 342). ${ }^{10}$

De fato, Parkes reconhece, no Chemical Catechism, que o arsênico é venenoso, e que se um grão de arsênico branco for administrado de uma única vez a uma pessoa, o resultado poderia ser até mesmo a morte. Ainda assim, Parkes não dá instruções sobre como manipular o produto do experimento, ou sobre como tornar o procedimento mais cauteloso. Ele apenas diz que, se alguma quantidade for ingerida propositalmente ou por engano, a solução seria administrar "sulfureto de potássio" dissolvido em água (PARKES, 1812, p. 342).

Além disso, Parkes também adiciona, nas notas de rodapé do Chemical Catechism, muitas recomendações de outras obras com experimentos que ele julga interessantes e que têm relação com os tópicos mencionados, para que o tutor os procure e os demonstre ao aprendiz, caso considere necessário. Entre essas recomendações encontram-se obras de Lavoisier, John Roebuck (1718-1794), Richard Chevenix (ca. 1774-1830) e Joseph Priestley (PARKES, 1812).

\subsection{2 "Seletos experimentos instrutivos"}

Os experimentos encontrados no capítulo "Seletos experimentos instrutivos" do Chemical Catechism tinham um objetivo diferente dos experimentos propostos nas notas de rodapé. Na introdução ao capítulo presente na segunda edição, Parkes ressalta que o intento original dos experimentos era explicar a razão de cada resultado experimental ao pupilo e os conceitos que os experimentos ilustram. Todavia, ele afirma, essa forma de aplicação da prática poderia vir a minar o espírito inquisitivo que deve ser cultivado na juventude, e, por isso, Parkes decidiu que apenas apresentaria a forma de conduzir os experimentos e que caberia ao aluno a

${ }^{10}$ A combustão do arsênio metálico com o oxigênio resulta em trióxido de arsênio, um composto tóxico muito conhecido popularmente pelo nome de arsênico, veneno que pode ser mortal se ingerido ou inalado (NATIONAL OCEANIC AND ATMOSPHERIC ADMINISTRATION, 1999d). 
busca da explicação das causas e efeitos, de acordo com o aprendido no Chemical Catechism. Para isso, Parkes aponta, ao final de cada experimento, as páginas referentes aos conceitos envolvidos na explicação, para que o pupilo viesse a consultá-las em sua busca de entendimento para o fenômeno observado. Ele ainda destaca que o pupilo não deveria seguir para o experimento seguinte enquanto não estivesse completamente satisfeito com a explicação elaborada por ele mesmo para o experimento anterior (PARKES, 1807a).

Os experimentos apresentados no capítulo, em sua grande maioria, possuem forte apelo sensorial, ou seja, apelam fortemente para os sentidos do ser humano (PARKES, 1812). Como exemplo, destacamos primeiramente um experimento que faz uso do tato como chave para a percepção do experimento:

1. Pegue um pequeno frasco e preencha metade com água fria; segure-o suavemente na mão esquerda e, de outro frasco, despeje um pouco de ácido sulfúrico gradualmente na água. Uma SENSAÇÃO DE CALOR forte será imediatamente percebida. Isto, pela adição contínua do ácido, pode ser aumentado para muitos graus além da água fervente. Veja as páginas 73 e 84 (PARKES, 1812, p. 475, destaque no original).

Analogamente, experimentos que apelam para os sentidos de visão, audição e olfato podem ser encontrados em meio aos experimentos propostos no capítulo, como se pode observar nos exemplos abaixo:

33. Fixe um pequeno pedaço de fósforo sólido em uma pena, e escreva com ela no papel. Se o papel for levado para um quarto escuro, a escrita ficará BELAMENTE LUMINOSA. Veja a página 262 (PARKES, 1812, p. 480 , destaque no original).

36. Pegue cerca de seis grãos de oximuriato de potássio [clorato de potássio] e três grãos de enxofre em pó; esfregue-os juntos em um 
almofariz, e um penetrante RUÍDO DE DETONAÇÃO será produzido. Continue a esfregar a mistura com força, e os resultados serão frequentemente repetidos, acompanhados de vívidos flashes de luz. Se a mesma mistura for embrulhada em papel, colocada sobre uma bigorna e rapidamente golpeada com um martelo, o ruído será tão alto quanto o que normalmente é produzido por uma pistola. Veja a página 221 (PARKES, 1812 , p. 480 , destaque no original).

159. Pegue um pequeno pedaço de fosfureto de cal [fosfeto de cálcio], um pouco umedecido pelo ar, e deixe cair uma única gota de ácido muriático concentrado sobre ele. Neste caso, o hidrogênio fosforado [fosfina] também será desprendido, acompanhado de PEQUENAS ESFERAS DE FOGO lançados da mistura, e do cheiro fétido mais intolerável que pode ser concebido. Consulte a página 256 (PARKES, 1812, p. 497, destaque no original).

Neste último experimento, pode-se observar que o apelo não é apenas relativo a um único sentido, o olfato, mas também à visão, o ponto chave de muitos dos experimentos. Sendo assim, muitos experimentos apelam conjuntamente para mais de um sentido. O único sentido que não é explorado é o paladar, embora existam pouquíssimas menções ao sabor de alguns compostos produzidos em um experimento. Como exemplo, podemos apontar o experimento proposto por Parkes para a produção de cloreto de amônio, também conhecido como sal amoníaco (PARKES, 1812):

24. Pegue o carbonato de amônio (o comum sal aromático volátil), e despeje sobre ele ácido muriático enquanto a efervescência continuar. $O$ produto será um SAL SÓLIDO, perfeitamente inodoro e de pouco gosto. Veja a página 165 (PARKES, 1812, p. 479, grifo e destaque no original). 
A menção ao gosto do sal amoníaco é bem fugaz, não fazendo parte exatamente do atrativo do experimento e nem da proposta de análise propriamente dita, mas sim de uma breve descrição do resultado de uma reação química (PARKES, 1812).

Os "Seletos experimentos instrutivos" foram apresentados ao leitor em formato de lista e numerados, e sua quantidade varia de acordo com a edição consultada. A primeira edição do Chemical Catechism contou com a menor de todas as listas: 154 experimentos selecionados pelo autor. Essa seleção foi grandemente ampliada na edição seguinte, com o acréscimo de 91 experimentos à lista original, totalizando 245 experimentos. Da segunda para a terceira edição, o autor acrescentou mais dois experimentos a essa relação, além de mais uma seleção de oito experimentos recomendados por Humphry Davy, a quem Parkes (1808, p. 592) agradece educadamente por meio de uma nota: "Para os seguintes experimentos eu estou em débito com a gentil comunicação do Professor Davy". No total, a terceira edição soma 255 experimentos em sua lista, um a menos que a quarta edição, que contou com um acréscimo na lista de recomendações de Davy. A relação de 256 experimentos se repetiu nas duas edições seguintes, e apenas se modificou da sexta para a oitava edição, com a exclusão do experimento de número 29 (25 na primeira edição) (PARKES, 1807b, 1807a, 1808, 1812, 1814, 1826a).

O motivo pelo qual o experimento 29 foi suprimido não é claro, pois não há justificativa no texto de Parkes. Uma possibilidade é que ele tenha sido retirado devido à periculosidade do produto da reação proposta, que no próprio texto é salientado como um fluido corrosivo:

29. Pegue uma porção de sulfato de ferro seco e uma quantidade igual de nitrato de potássio, triture-os juntos em um almofariz, e coloque tudo em uma pequena retorta de vidro. Adapte um receptor à retorta com uma ou duas garrafas, de acordo com o projeto do Aparelho de Woulfe, e aplique o calor de uma lâmpada de Argand. Depois de algum tempo, um gás será desprendido, que será condensado pelos receptores frios formando o verdadeiro ácido nitroso. Temos aqui um FLUIDO CORROSIVO produzido 
a partir da mistura de duas substâncias brandas e sólidas(PARKES, 1808,

p. 561, destaque no original)

Considerando, porém, que outros experimentos propostos por Parkes envolviam riscos ainda maiores, não deve ter sido esta a causa da exclusão. Outra hipótese, então, é que o experimento tenha sido excluído por não produzir o resultado esperado em sua execução. É difícil, para o leitor moderno, determinar exatamente qual o produto pretendido, considerando a variedade de produtos que podem ser formados, e que a nomenclatura dada a eles na época não era a mesma que a atual. Além disso, os reagentes poderiam conter impurezas não determinadas, mas que poderiam ser fundamentais para a obtenção ou não do produto esperado.

A lista de experimentos permaneceu com 255 itens nas quatro edições seguintes. Nove anos após a morte de Samuel Parkes, e oito anos após o lançamento da décima segunda edição, alguns experimentos voltaram a ser retirados na décima terceira edição, lançada em 1834. Essa segunda edição póstuma conta com algumas mudanças mais expressivas do que as edições anteriores, dado que, na altura do falecimento de Parkes, ele havia deixado anotações sobre mudanças e adições que pretendia fazer no texto. Tais alterações foram seguidas fielmente, segundo seu genro Joseph W. Hodgetts (1826b, p. xv$x v i)$. Por isso, a décima segunda edição pode ser considerada autorizada pelo próprio Parkes, diferentemente da edição seguinte (PARKES, 1818, 1819, 1822, $1824,1826 b)$.

Encarregado de atualizar e alterar o Chemical Catechism, Edward William Brayley modificou a edição anterior para incrementar o texto de Parkes com as novas descobertas e estudos científicos dos oito anos decorridos entre as edições, bem como retificar conceitos que haviam sido modificados devido ao progresso da ciência. Brayley buscou não omitir ou modificar radicalmente o texto principal da obra de Parkes. Diante de concepções expressas por Parkes que foram superadas pelo avanço científico, Brayley optou por preservar o texto original, adicionando as correções necessárias em vez de eliminar o tópico. Reduziu, porém, a lista de experimentos: na edição revisada por Brayley, o Chemical Catechism passou a listar 246 experimentos, nove a menos do que a versão anterior (PARKES, 1826b, 1834). 
Para uma análise mais aprofundada das modificações e variações nas listas de experimentos de uma edição para outra, escolhemos a quinta edição do Chemical Catechism, lançada em 1812, como parâmetro comparativo, por ser uma das edições que apresentam o maior número de "seletos experimentos instrutivos" e por estabelecer um padrão de texto que foi mantido na maioria das edições seguintes.

Para efeito de comparação e análise, produzimos uma tabela (Apêndice) na qual correlacionamos os experimentos que constam da primeira, segunda, terceira, quarta, quinta, sexta, oitava, nona, décima, décima primeira, décima segunda e décima terceira edições do Chemical Catechism, de acordo com os números que identificam os experimentos em cada edição, o que permite identificar acréscimos e supressões. A ausência da sétima edição se deve a sua não disponibilidade nas bibliotecas online que foram consultadas. Vale ressaltar que, também por indisponibilidade de acesso, a primeira edição analisada não foi a versão original britânica de 1806, mas a versão estadunidense publicada em 1807. Essa edição sofreu poucas alterações em comparação com a original britânica de 1806, como a adição de uma ilustração do laboratório de James Woodhouse (1770-1809), professor de química da Universidade da Pensilvânia. As demais edições analisadas são todas britânicas (PARKES, 1807b, 1807a, 1826b, 1834, 1808, 1810, 1812, 1814, $1818,1819,1822,1824)$.

Além das alterações na quantidade de experimentos, alterações em procedimentos ou descrições também ocorreram com certa frequência de uma edição para outra do Chemical Catechism. No Apêndice, essas alterações estão representadas pelos números destacados pelas cores azul, verde, vermelha e laranja, cada uma significando um tipo de alteração.

O primeiro e mais frequente tipo de alteração (destacado na tabela pela cor azul) se refere a modificações no texto ou modo de escrita, sem que o procedimento seja significativamente alterado e sem que o resultado seja modificado. Essas alterações podiam ser sutis, como a mudança na narrativa de um experimento. É o caso do experimento 61 da quinta edição, que recebeu um enunciado diferente na décima terceira edição, embora tenham sido mantidos o procedimento e o resultado. Aqui também se incluem atualizações da nomenclatura de compostos; por exemplo, 
o "muriato oxigenado de potássio", como era chamado na primeira edição, passou a ser "oximuriato de potássio" da segunda edição em diante, até receber o nome de "clorato de potássio" nas edições a cargo de Brayley. Em suas revisões, Brayley optou por substituir os nomes populares ou antigos de algumas substâncias pelos seus nomes modernos, como a substituição de "prussiato de potássio" por "ferrocianato de potássio", ou de "ácido nitroso de objetivo comercial" por "ácido nítrico" na décima terceira edição. Também foram considerados aqui os acréscimos de texto, como no caso do experimento 55 da primeira edição, que recebeu acréscimo de uma nota de segurança e foi renumerado como experimento 60 nas edições seguintes. Em outros casos, o autor forneceu mais informações ao leitor sem modificar o restante do texto - como no experimento 44 da primeira edição, que a partir da segunda edição (renumerado como 49) passou a especificar que a cor resultante da mistura de prussiato de potássio com uma solução de sulfato de cobre se devia ao prussiato de cobre. Finalmente, estão incluídas aqui pequenas mudanças referentes ao modo de dimensionar as quantidades de reagentes, como a mudança de "uma onça" para "um pouco", ou de "alguns pedaços" para "alguns fios", e outras similares (PARKES, 1807b, 1812, 1834).

O segundo tipo de alteração (destacado na tabela pela cor verde) ocorreu uma única vez, e se refere a um experimento em cujo texto houve a correção de uma informação que teria sido fornecida erroneamente nas edições anteriores. Trata-se do experimento de número 174 da segunda edição, na qual o nitrato de prata foi identificado como sendo o "cáustico lunar"; da terceira edição em diante, a mesma substância foi identificada como não sendo o "cáustico lunar":

174. Se um bocado de nitrato de prata seco (cáustico lunar) for colocado em um pedaço de carvão ardente, o sal metálico irá deflagrar imediatamente, expelir as mais belas cintilações que podem ser imaginadas, e a superfície do CARVÃO será ricamente REVESTIDA COM PRATA METÁLICA (PARKES, 1807a, p. 573, destaques no original).

174. Se um bocado de cristais secos de nitrato de prata (não o cáustico lunar) for colocado em um pedaço de carvão ardente, o sal metálico irá 
deflagrar imediatamente, expelir as mais belas cintilações que podem ser imaginadas, e a superfície do CARVÃO será ricamente REVESTIDA COM PRATA METÁLICA (PARKES, 1812, p. 499, destaques no original).

Entretanto, Parkes não forneceu qualquer explicação sobre qual seria a diferença entre o nitrato de prata seco em cristais e o nitrato de prata seco, "cáustico lunar" (que é um nome antigo atribuído a essa substância, ainda hoje utilizado no contexto comercial). É possível que a diferença se dê exatamente porque "cáustico lunar" era o nome dado ao nitrato de prata quando em formato de bastão para cauterização de ferimentos, e não em forma de cristais (HIRA; LEWIS, 1970).

O terceiro tipo de alteração (destacado na tabela pela cor vermelha) se refere a um experimento cujo procedimento foi bastante alterado, ainda que o resultado e a conclusão do experimento tenham sido os mesmos. Trata-se do experimento 6 da primeira e segunda edições, cujo procedimento foi totalmente modificado da terceira edição em diante, conforme se mostra a seguir:

6. Encha um frasco de vidro com água, inverta-o sobre a prateleira de uma cuba pneumática; e tendo aquecido ao rubro um atiçador de ferro comum, mergulhe-o dentro da água sob o jarro. Neste caso, uma parte da água também será decomposta e GÁS HIDROGÊNIO ascenderá através da água até a parte superior do jarro (PARKES, 1807b, p. 294, destaque no original).

6. Despeje a água em uma pequena retorta de vidro até ocupar cerca de um terço de sua capacidade, vede seu bico no final de um cano de arma, o meio do qual deve ser mantido em brasa em uma fornalha, ou por um fogareiro; então, se uma lâmpada for aplicada à retorta, de modo a causar a água a ferver, o vapor vai passar através do tubo de ferro em brasa, e neste caso [a água] também será decomposta; pois, como o oxigênio combina com o ferro, o GÁS HIDROGÊNIO será liberado, e poderá ser coletado da maneira usual (PARKES, 1812, p. 476, destaque no original). 
Observa-se que o segundo procedimento sugerido para a decomposição térmica da água é muito mais elaborado que o primeiro, e acompanha o procedimento sugerido pioneiramente por Lavoisier como evidência do caráter composto da água. Esse experimento está descrito e ilustrado, por exemplo, no Tratado Elementar de Química de Lavoisier, publicado originalmente em 1789 (LAVOISIER, 2007, p. 6768). Não é difícil imaginar que a quantidade de hidrogênio produzida com o primeiro procedimento devia ser muito pequena (ou mesmo não observável), o que explica a necessidade da mudança.

Por fim, o quarto tipo de alteração (destacado na tabela pela cor laranja) se refere a experimentos nos quais o procedimento foi alterado pela inclusão de um reagente ausente na versão anterior. Pode-se citar como exemplo o experimento 120 da quinta edição, cuja descrição, da oitava edição em diante, passa a incluir nitrato de potássio no procedimento de oxidação do enxofre a "ácido sulfúrico" (ou anidrido sulfúrico, na nomenclatura atual):

120. Coloque um pouco de enxofre comum em um prato de ferro, coloque debaixo de um jarro de gás oxigênio, e ateie fogo a ele como instruído na página 172, e ácido sulfúrico será formado. Isto é um exemplo de formação de um ÁCIDO POR COMBUSTÃO (PARKES, 1812, p. 492, destaque no original).

240. Coloque um pouco de enxofre comum, com um oitavo do seu peso de nitro [nitrato de potássio], em um prato de ferro, coloque-o debaixo de um jarro de gás oxigênio, e ateie fogo a ele como instruído na página 210, e ácido sulfúrico será formado. Isto é um exemplo de formação de um ácido por combustão (PARKES, 1834, p. 592).

Como se pode também observar pela organização dos experimentos do Apêndice, até a sexta edição houve poucas alterações na organização dos experimentos, que em geral seguiram uma mesma ordem de aparição, mesmo 
considerando as adições feitas de uma edição para outra. Observa-se apenas que o experimento 125 da primeira edição foi realocado para corresponder ao experimento 111 das edições seguintes. Provavelmente Parkes fez essa alteração para que o experimento 111 (125 na primeira edição), que se refere a sublimação, ficasse junto ao experimento 110, que trata do mesmo tema (PARKES, 1807b, 1807a, 1808, $1810,1812,1814)$.

As listas de experimentos, até a sexta edição, não seguiam um critério claro de encadeamento ou separação, embora fosse frequente que experimentos de execução muito similar fossem agrupados em sequência. Entre a sexta e a oitava edição, no entanto, a ordem seguida anteriormente foi completamente posta de lado, e um novo arranjo sequencial foi adotado. Os experimentos passaram a ser separados em categorias, embora a numeração tenha permanecido contínua (PARKES, 1807b, 1807a, 1834, 1808, 1810, 1812, 1814, 1818, 1819, 1822, 1824).

Da oitava edição em diante, Parkes classificou seus experimentos em dez categorias, que podem ser observadas na tabela a seguir:

Tabela 1: Tabela com as categorias criadas por Parkes a partir da oitava edição do Chemical Catechism (PARKES, 1818, 1819, 1822, 1824, 1826b, 1834).

\begin{tabular}{|l|c|c|}
\hline \multicolumn{1}{|c|}{ Nomes das seções } & $\begin{array}{c}8^{\underline{a}} \text { à } 12^{\underline{a}} \\
\text { edição }\end{array}$ & $\begin{array}{c}13^{\underline{a}} \\
\text { edição }\end{array}$ \\
\hline I. Experimentos sobre Mudança de Temperatura: & 1 a 19 & 1 a 18 \\
\hline II. Sobre os Gases: & 20 a 45 & 19 a 43 \\
\hline III. Sobre a Formação e Cristalização de Sais: & 46 a 58 & 44 a 56 \\
\hline IV. Experimentos sobre cores: & 59 a 83 & 57 a 81 \\
\hline V. Sobre Tingimento e Impressão em Calicô: & 84 a 96 & 82 a 94 \\
\hline VI. De Combustão e Detonação: & 97 a 138 & 95 a 133 \\
\hline VII. Tintas Simpáticas: & 139 a 149 & 134 a 144 \\
\hline VIII. Alguns Experimentos com as Terras: & 150 a 161 & 145 a 156 \\
\hline IX. Experimentos com os Metais: & 162 a 241 & 157 a 234 \\
\hline X. Experimentos Diversos: & 242 a 255 & 235 a 246 \\
\hline
\end{tabular}


$\mathrm{Na}$ categorização feita por Parkes, como mostrado na Tabela 1, agrupamentos de experimento foram feitos pela similaridade quanto à sua proposta ou o objetivo do experimento. Para esta análise, usamos a lista de experimentos presente na oitava edição, por ser a primeira a ter sido categorizada por Parkes (PARKES, 1818). Além disso, na discussão a seguir, propomos subcategorias que agrupam experimentos semelhantes dentro de cada uma das categorias.

$\mathrm{Na}$ categoria I, Experimentos sobre Mudança de Temperatura, a grande maioria gira em torno da influência do calórico sobre os estados físicos da matéria, assim como de sua atuação na mudança de temperatura das substâncias. A presença do calórico pode ser encontrada de forma implícita ou explícita. Na forma implícita, embora não haja menção ao calórico no enunciado, a página indicada por Parkes ao final do experimento, para que o pupilo buscasse o fundamento para explicar o experimento proposto, direcionava-o a um amplo texto acerca do calórico. Isso pode ser observado nos experimentos de números 1, 2, 3, 6, 7, 8, 9, 10, 11, 12, 13 e 15 (PARKES, 1818). A seguir, apontamos como exemplo o experimento de número 3 da oitava edição do Chemical Catechism:

3. Se o aluno estiver de posse de uma bomba de ar, a seguinte experiência pode ser facilmente realizada: - Deixe-o fixar um pequeno copo de estanho contendo éter dentro de um grande vidro de relógio contendo um pouco de água, e coloque ambos sob o receptáculo da bomba de ar. A exaustão do receptáculo fará com que um dos fluidos FERVA, e o outro CONGELE NO MESMO INSTANTE. Ver nota, página 42 (PARKES, 1818, p. 523, destaque no original).

Na página apontada por Parkes ao final do procedimento, encontra-se uma extensa nota de rodapé em que o autor propõe o mesmo experimento e explica que, quando a pressão da atmosfera é removida da superfície do éter, o seu calórico latente ocasiona a sua expansão, fazendo com que o calórico da água seja absorvido pelo éter. Dessa forma, o éter se converte em gás, consequentemente fazendo com que a água perca o seu calórico e congele. Embora o calórico não 
estivesse presente no enunciado do experimento, a sua citação claramente seria necessária para que uma explicação fosse elaborada (PARKES, 1818).

Por outro lado, nos experimentos 4, 5, 14 e 18, o calórico é explicitamente mencionado como responsável pelo fenômeno observado (PARKES, 1818). Como exemplo, podemos citar o experimento 14:

14. Pegue um copo de água fria, despeje um pouco de éter sulfúrico em sua superfície, e incendeie-o com um pedaço de papel aceso. O éter queimará por um tempo considerável, e produzirá um grande volume de chama, mas quando se extinguir, a água não terá aumento de temperatura. A proposta deste experimento é mostrar que A ÁGUA É UM MAU CONDUTOR DE CALÓRICO, e que quando desejamos aquecer a água, o calor não deve ser aplicado em sua superfície. Veja parte da notab, página 73 (PARKES, 1818, p. 525, destaque no original).

Os experimentos 16, 17 e 19 tratam da influência da temperatura na apresentação das cores de metais ou soluções de sais (PARKES, 1818). Como exemplo, podemos citar o experimento 16:

16. Coloque em um copo de vinho um pouco de manganês oxidado e nitrato de potassa [salitre], preparado como indicado na página 314, e uma quantidade igual do mesmo composto em outro copo. Em um despeje [água] quente, e no outro, água fria. A SOLUÇÃO QUENTE exibirá uma BONITA cor VERDE; a FRIA, um ROXO PROFUNDO (PARKES, 1818, p. 526, destaque no original).

A segunda categoria é intitulada Sobre os Gases. Nela, uma grande subcategoria pode ser formada abrangendo os primeiros experimentos propostos, numerados de 20 a 34 . Os onze primeiros desses experimentos consistem na 
produção ou obtenção de gases, como no exemplo do experimento 24 (PARKES, 1818):

24. Coloque uma ou duas onças de óxido preto de manganês em uma pequena retorta de vidro, coloque um pouco de ácido sulfúrico concentrado sobre ele e aplique o calor de uma lâmpada. GÁS OXIGÊNIO será desprendido em abundância (PARKES, 1818, p. 527, destaque no original).

Após essa grande sequência de experimentos muito parecidos entre si, duas duplas de propostas similares são apresentadas: os experimentos 31 e 32, que tratam da obtenção de um sólido por meio da mistura de dois gases; e os experimentos 33 e 34, que tratam da detecção de compostos por meio de amônia e ácido muriático (PARKES, 1818).

A segunda subcategoria bem delimitada dentro da categoria Sobre os Gases consiste em apenas quatro experimentos sobre combustão, de números 36, 37, 38 e 39, sendo os três primeiros acerca da inflamabilidade da mistura de hidrogênio com oxigênio, enquanto o último trata da combustão de metais (níquel, arsênico ou bismuto em pó) não em oxigênio, mas em gás ácido oximuriático (gás cloro).

Os experimentos restantes, de números 35, 41, 42, 43, 44 e 45, trazem exemplos de fenômenos variados tocantes aos gases. O experimento 35 ilustra como o balão de hidrogênio ascende na atmosfera. $O$ experimento 40 se destina a demonstrar que o ácido carbônico (gás carbônico) pode ser decomposto, sendo um de seus componentes o carvão. O experimento 41 mostra como o mesmo gás ácido carbônico é capaz de apagar a chama de uma vela. O experimento 42 mostra que os gases produzidos pelas misturas do ácido sulfúrico com acetato de potássio e da cal viva com sal amoníaco formam um produto visível (isto é, formam um sólido que fica em suspensão no ar) quando colocados lado a lado e se misturam. O experimento 43 trata de como o gás oxigênio provavelmente estimula a luminosidade do vaga-lume. O experimento 44 trata da formação de um ácido por meio da mistura de dois gases, e o experimento 45 se refere à necessidade de água 
para a ocorrência de algumas decomposições químicas, liberando gás (PARKES, 1818).

A terceira categoria, denominada Sobre a Formação e Cristalização de Sais, começa apresentando ao leitor uma série de experimentos que mostram fenômenos relacionados à cristalização. No experimento 46, Parkes propõe um experimento cujo objetivo é demonstrar que cada tipo de sal possui uma forma preestabelecida instilada nele próprio, enquanto o experimento 47 propõe uma prática para demonstrar a influência do ar atmosférico na cristalização dos sais. Por sua vez, o experimento 48 retoma o tema do calórico e propõe um experimento para mostrar que soluções salinas expelem calórico durante a cristalização. O experimento 52 mostra como a temperatura influencia os diferentes graus de oxidação, que por sua vez afetam as cores dos óxidos metálicos precipitados (PARKES, 1818).

Pode-se agrupar uma subcategoria de experimentos similares entre si, reunindo os experimentos $50,53,54,55,56$ e 58 . Todos eles propõem a obtenção de sais por meio da mistura de duas soluções, como pode ser visto no exemplo a seguir (PARKES, 1818):

53. Tome uma onça de uma solução de soda cáustica, despeje sobre ela meia onça de ácido sulfúrico; deixe a mistura em repouso, e quando estiver fria, cristais de sulfato de sódio serão formados na solução. Aqui, um SAL SUAVE foi FORMADO a partir de uma mistura de duas substâncias corrosivas (PARKES, 1818, p. 532, destaque no original).

Outra subcategoria reúne os experimentos 49, 51 e 57, que têm como propósito exemplificar como uma solução pode conter metais dentro de si, como podemos ver no experimento 51 (PARKES, 1818):

51. Coloque uma pequena quantidade de ácido nitroso forte em um copo de vinho, adicione duas vezes a sua quantidade de água destilada, e, quando misturado, jogue alguns pedaços muito pequenos de estanho 
granulado nele. Uma efervescência violenta ocorrerá, as partículas mais leves do estanho serão lançadas para o topo do ácido, e serão vistas indo para cima e para baixo na solução por um tempo considerável, até que tudo seja dissolvido. Este é outro exemplo de um LíQUIDO TRANSPARENTE contendo um METAL EM SOLUÇÃO (PARKES, 1818, p. 531, destaque no original).

Na quarta categoria, intitulada Experimentos sobre cores, identificamos quatro subcategorias. A primeira, que abrange os experimentos 59, 60, 61, 62, 71, 72, 73 e 74, possui como temática conjunta a relação entre a mudança de cor de uma solução com testes para detecção de ácidos e bases (PARKES, 1818). Como exemplo, podemos citar o experimento 60:

60. Prepare um pouco de tintura de tornassol. Sua cor será um azul brilhante com um tom de roxo. Coloque um pouco em um frasco e adicione algumas gotas de ácido muriático diluído; sua cor mudará para um vermelho vívido. Adicione um pouco de solução de potassa [hidróxido de potássio]; o vermelho agora desaparecerá e o azul será restaurado. Por estes meios, a solução pode ser mudada alternadamente de vermelho para azul, e de azul para vermelho, à vontade. Um exemplo dos efeitos de ácidos e álcalis em MUDAR AS CORES DE VEGETAIS (PARKES, 1818, p. 533, destaque no original).

A segunda subcategoria consiste na mudança de cor quando duas substâncias são misturadas, sendo esta mudança provocada não por conta de uma detecção de ácidos e bases, como na subcategoria anterior, mas pela reação química que ocorre entre as duas soluções. Nesta subcategoria, podemos incluir os experimentos 63, 64, 65, 66, 67, 68, 69 e 70 (PARKES, 1818). Como exemplo, apresentamos o experimento 63: 
63. Em um copo de vinho contendo água coloque algumas gotas de prussiato de potassa; e um pouco de solução diluída de sulfato de ferro em outro copo: ao despejar esses dois fluidos incolores juntos, uma BRILHANTE COR AZUL PROFUNDA será imediatamente produzida, que é o verdadeiro azul da Prússia (PARKES, 1818, p. 533, destaque no original).

O experimento 70, enquadrado nesta subcategoria, trata da não formação de cor ao se modificar as condições do experimento 69 (no qual se forma 0 característico azul da Prússia). No experimento 69, mistura-se uma solução de carbonato de ferro com prussiato de potassa; no experimento 70, Parkes sugere ferver a mesma solução inicial de carbonato de ferro antes de misturá-la à solução de prussiato de potassa, o que impede a formação do azul da Prússia e o consequente aparecimento da cor característica (PARKES, 1818).

A terceira subcategoria consiste na coloração conferida à chama pela combustão de certos compostos, podendo também servir como testes de detecção de tais substâncias. Nesta subcategoria se enquadram os experimentos 75, 76, 77 e 78 (PARKES, 1818). A seguir, apontamos o experimento 75 como exemplo:

75. Se uma colher cheia de um bom álcool e um pouco de ácido borácico forem misturados em uma xícara de chá e, em seguida, incendiados, eles produzirão uma CHAMA VERDE muito bonita (PARKES, 1818, p. 534, destaque no original).

A quarta subcategoria presente entre os Experimentos sobre cores abrange os experimentos $79,80,81,82$ e 83, que relacionam a influência da luz do sol na cor produzida por uma solução de ouro em diferentes condições (PARKES, 1818). Podemos exemplificar citando o experimento 79 : 
79. Evapore até a secura uma solução de ouro, feita com ácido nitromuriático [água régia], e dissolva os cristais com água pura suficiente para evitar a cristalização do sal metálico. Umedeça cuidadosamente um pouco de magnésia [carbonato de magnésio] com esta solução aquosa e exponha a mistura aos raios solares. Uma mudança de cor logo será aparente. Primeiro, ela tomará uma tonalidade VIOLETA FRACA e, em poucas horas, tudo terá adquirido um ROXO muito PROFUNDO (PARKES, 1818 , p. 535, destaque no original).

A quinta categoria proposta por Parkes, intitulada Sobre Tingimento e Impressão em Calicô, não consiste apenas, como o nome sugere, de uma sequência de experimentos acerca do tingimento do tecido calicô, em geral para fins comerciais, mas também trata do tingimento de couro, lã e linho. Os experimentos presentes nesta categoria são os de números 84 a 96 (PARKES, 1818). Como exemplo, citamos o experimento 88:

88. Tendo encontrado um pedaço de pano de linho azul, que irá descorar em ácido muriático oxigenado, mergulhe a ponta do dedo em uma solução de muriato de estanho, e pressione-o, enquanto molhado com a solução, sobre uma tira desse pano. Após um intervalo de alguns minutos, mergulhe o pano em um frasco de ácido oximuriático líquido, e quando ele houver permanecido pelo tempo usual, será visto que o local que foi previamente molhado com muriato de estanho preservou sua COR ORIGINAL, enquanto o restante do pano ficou BRANCO (PARKES, 1818, p. 536, destaque no original).

Apenas dois experimentos nesta categoria não tratam diretamente do tingimento de algum tipo de tecido ou couro. O experimento 85 descreve a dissolução de matérias corantes de origem vegetal e sua subsequente precipitação na presença de alúmen. O experimento 92 trata da produção da tinta nanquim (PARKES, 1818). 
A sexta categoria reúne os experimentos que tratam De Combustão e Detonação, os quais podem ser divididos em três subcategorias. Os experimentos $97,99,100,101,102,109,111,117,118,119,120,121,122,124,125,126,134$, 135, 136, 137 e 138 consistem em reações de combustão que não requerem qualquer estímulo externo, seja aquecimento, fogo ou percussão mecânica, isto é, a combustão resulta puramente da reação química entre as substâncias utilizadas (PARKES, 1818). Como exemplo, citamos o experimento 109:

109. Coloque um pouco de água pura em um pequeno copo de vidro e coloque nele um ou dois pedaços pequenos de fosfureto de cal [fosfeto de cálcio]. Em pouco tempo FAÍSCAS DE FOGO sairão da superfície da água e terminarão em anéis de fumaça, que ascenderão em sucessão regular (PARKES, 1818, p. 540, destaque no original).

Na segunda subcategoria, os experimentos $98,105,106,107,108,110,115$, 116, 123, 127, 128, 129 e 132 abordam combustões nas quais é necessário um estímulo exterior, como se pode observar no experimento 98 (PARKES, 1818):

110. Coloque trinta grãos de fósforo em um frasco de Florença, com três ou quatro onças de água. Coloque o recipiente sobre uma lâmpada e aqueça-o até a ebulição. Bolas de fogo em breve serão vistas saindo da água, como se fossem fogos de artifício, acompanhadas pelas mais belas coruscações. Um experimento para mostrar a extrema INFLAMABILIDADE DO FÓSFORO (PARKES, 1818, p. 540, destaque no original).

Os experimentos 103, 112, 113 e 114 podem ser reunidos em uma subcategoria, pois tratam da produção de luminosidade não originada de combustão ou detonação, tal como a luminosidade emitida pelo fósforo ou pelo éter fosforetado. Como exemplo, citamos o experimento 114 (PARKES, 1818): 
114. Se qualquer parte do corpo for esfregada com fósforo líquido ou éter fosforetado, essa parte, em um quarto escuro, aparecerá como se estivesse EM CHAMAS, sem produzir qualquer efeito perigoso ou sensação de calor (PARKES, 1818, p. 538, destaque no original).

Os experimentos 104, 130, 131 e 133 não se enquadram em nenhuma dessas subcategorias. O experimento 104 trata da combustibilidade relativa de diferentes substâncias ao serem queimadas em um jarro contendo gás oxigênio. $O$ 130 é um exemplo de formação da água por meio da combustão. O experimento 131 mostra como obter potássio decompondo a potassa com o uso de uma bateria galvânica, sendo seguido pelo experimento 132 (um dos exemplos de combustão com influência externa, já mencionado anteriormente), no qual Parkes explica como fazer o potássio voltar ao seu estado de potassa por meio da combustão. Em seguida, o experimento 133 continua tratando do potássio, abordando sua gravidade específica - diferindo, assim, dos demais experimentos desta categoria, pois não se trata de uma combustão (PARKES, 1818).

A sétima categoria criada por Parkes, chamada Tintas Simpáticas, reúne o menor número de experimentos, e pode ser dividida em duas subcategorias. A primeira, compreendendo os experimentos 139, 140, 141 e 142, apresenta tintas que, embora em temperatura ambiente fiquem invisíveis ao secar sobre um papel, ao serem submetidas a alguma fonte de calor tornam-se coloridas (PARKES, 1818). Como exemplo, podemos citar o experimento 142:

142. Desenhe uma paisagem com nanquim e pinte a folhagem dos vegetais com muriato de cobalto, o mesmo que o usado no Experimento №140, e algumas das flores com acetato de cobalto, e outras com muriato de cobre. Enquanto esta imagem estiver fria, ela parecerá meramente um contorno de uma paisagem, ou uma cena de inverno; mas quando aquecidas delicadamente, as árvores e as flores serão MOSTRADAS EM SUAS CORES NATURAIS, que elas conservarão apenas enquanto continuarem aquecidas. Isso pode ser repetido com frequência (PARKES, 1818 , p. 545, destaque no original). 
Os demais experimentos desta categoria, de números 143, 144, 145, 146, 147, 148 e 149, partem do mesmo princípio que os anteriores, sendo tintas invisíveis quando usadas no papel - as quais, porém, se tornam visíveis ao se adicionar outra substância sobre elas, como pode ser visto no experimento 143 (PARKES, 1818):

143. Escreva com nitrato de prata diluído, que quando seco será completamente invisível; segure o papel sobre um recipiente contendo sulfato de amônia, e a escrita aparecerá bem distinta. As letras brilharão com o ESPLENDOR METÁLICO da PRATA (PARKES, 1818, p. 545, destaque no original).

A oitava categoria, denominada Alguns Experimentos com as Terras, também é relativamente pequena, com apenas doze itens, dos quais dez são experimentos de precipitação: 150, 151, 153, 154, 155, 156, 157, 159, 160 e 161 (PARKES, 1818). Como exemplo, citamos o experimento 151 :

151. Coloque um pouco de água de cal em um frasco e jogue um pouco de ácido carbônico nele. $O$ ácido carbônico apreenderá a cal e a precipitará no estado de CARBONATO DE CAL (PARKES, 1818, p. 546, destaque no original).

Apenas dois experimentos na oitava categoria proposta por Parkes não resultam na formação de precipitados: o 152 e o 158. O experimento 152 é uma continuação do experimento 151, citado acima. As instruções dizem para pegar o frasco com o carbonato de cal obtido na prática anterior e adicionar uma porção extra de ácido carbônico, para se constatar que o carbonato de cal será redissolvido. Vale mencionar que, na sequência, o experimento 153 propõe que se pegue a solução transparente resultante do experimento 152 e a submeta ao aquecimento, para que o carbonato de cal volte a precipitar. O experimento 158, por sua vez, 
propõe um teste de detecção de ácido carbônico, instruindo o pupilo a adicionar uma pequena dose de qualquer outro ácido na água suspeita de conter ácido carbônico. Caso a suspeita se confirme, pequenas borbulhas de gás aparecerão nas paredes do frasco, assim como na superfície da solução (PARKES, 1818).

A nona categoria, Experimentos com os Metais, contém o maior número de experimentos: oitenta no total. Podemos dividi-la em diversas subcategorias. A primeira subcategoria consiste em experimentos que resultam em um composto precipitado, abrangendo os experimentos 162, 163, 164, 173, 174, 176, 177, 178, 179, 183, 184, 185, 191, 193, 194, 204, 212, 214, 215, 222 e 241 (PARKES, 1818). Como exemplo, citamos o experimento 179:

179. Se uma solução incolor de arsênico em potassa cáustica for vertida em uma solução incolor de cobre, um precipitado verde será produzido, formando um arseniato de cobre semelhante a um minério encontrado nas minas da Cornualha. Estes metais podem ser assim DETECTADOS RECIPROCAMENTE (PARKES, 1818, p. 550, destaque no original).

Esses experimentos, na maioria, sugerem apenas a precipitação visando o produto em si, para apontar a obtenção de um sal ou para demonstrar um precipitado de coloração interessante. Alguns experimentos ilustram a redissolução do precipitado, como os experimentos 177 e 194, nos quais o precipitado volta a se dissolver ao agitar o frasco. É interessante notar que alguns experimentos foram propostos com o objetivo de usar a precipitação para detecção de um metal específico, como os experimentos 173, 174 e 191. O experimento 173 menciona que, por meio dele, seria possível averiguar a quantidade de ferro presente em qualquer solução que contenha esse metal (PARKES, 1818).

Relacionado a esta subcategoria, encontramos o experimento 165, que propõe um método para separar sais metálicos, em especial o precipitado obtido no experimento 164: uma mistura de muriato de prata e sulfato de prata. Por meio de aquecimento, o sulfato de prata é redissolvido, deixando apenas o muriato de prata em forma de precipitado. O experimento 202, embora não seja um experimento de 
obtenção de precipitado, pode ser considerado um experimento de identificação de um metal - no caso, o mercúrio. O experimento propõe que um pouco de calomelano (cloreto de mercúrio I) seja friccionado em um almofariz com uma solução de amônia cáustica, resultando em uma mistura intensamente negra (PARKES, 1818).

Outra subcategoria, composta pelos experimentos 172, 181, 182, 197, 198, 213, 216 e 217, propõe métodos para se obter soluções aquosas de metais, algumas vezes necessitando do auxílio de substâncias como o açúcar (experimento 216) ou da luz dos sol (experimento 217) para efetivar a solubilização (PARKES, 1818). Como exemplo, podemos citar o experimento 216 :

216. Despeje um pouco de ácido nítrico puro sobre o óxido negro de manganês, e nenhuma solução será efetuada. Mas se um pouco de açúcar for adicionado, o AÇÚCAR irá EXTRAIR uma parte do OXIGÊNIO do ácido nítrico, e então o ácido será capaz de dissolver o metal (PARKES, 1818, p. 555 , destaque no original).

Nesta nona categoria podemos também compor uma grande subcategoria com os experimentos 175, 186, 187, 188, 189, 190, 207, 218, 219, 226, 227, 228, 229, 230, 231, 232, 233, 234, 235, 236, 237, 238, 239 e 240. Tais experimentos consistem em métodos de redução para obtenção de metais em seu estado metálico, com o objetivo de revestir tecidos, porcelanas, vigas de madeira ou mesmo outros metais, possivelmente com interesse comercial, como pode ser observado no experimento 234 (PARKES, 1818):

234. Se um pedaço de SEDA branca for mergulhada em uma solução aquosa de nitro-muriato de ouro, e exposto enquanto úmido ao gás ácido sulfuroso, a peça inteira será coberta em poucos segundos com uma camada de OURO REDUZIDO, que fica PERMANENTE (PARKES, 1818, p. 557-558, destaque no original). 
Outra subcategoria, consideravelmente menor, contendo apenas os experimentos 167, 192, 205, 206 e 225, também propõe experimentos para se obter metais em seu estado metálico - porém, sem outra aplicação prática além da obtenção do próprio metal em si. Nos experimentos 205 e 206, essa obtenção é acompanhada da detonação ou combustão de uma substância obtida paralelamente.

Os experimentos 169, 170 e 210, além de mostrar a redução de metais, também buscam impressionar o leitor com fenômenos curiosos ou interessantes, como a formação do que o autor chama de "vegetação metálica", obtenção de uma "árvore metálica", ou a formação da "árvore de Diana", respectivamente. Os experimentos 195 e 196, por sua vez, buscam mostrar ao leitor como os metais se tornam insolúveis quando separados do oxigênio, seja por meio de aquecimento com carvão, seja por meio da desoxidação causada pela luz do sol (PARKES, 1818).

O experimento 207 propõe uma sequência de oxirredução que parte de nitrato de prata e cobre metálico, fazendo a prata metálica precipitar; adicionando-se, em seguida, pedaços de ferro à solução de cobre, precipita-se o cobre metálico. Ao final do experimento, Parkes afirma que aquele era um "exemplo espetacular de AFINIDADES PECULIARES" (PARKES, 1818, p. 554, destaque no original).

Pode-se observar uma variedade de experimentos que demonstram fenômenos interessantes ou curiosos incluídos na nona categoria. O experimento 168, por exemplo, apresenta uma proposta para vitrificação de metais fazendo uso do chumbo, e o 224 descreve a obtenção do chamado vidro de antimônio (PARKES, 1818). O experimento 171 mostra a influência do ar atmosférico na coloração de uma solução de cobre; o 180 demonstra a "imutabilidade" dos metais nobres; enquanto o 201 sugere que um amálgama de chumbo e mercúrio seja misturado e triturado juntamente com um amálgama de bismuto, fazendo com que essa mistura se torne um fluido. O experimento 203 mostra que uma solução de sulfato de manganês, exposta ao "poder desoxidante dos raios solares" (PARKES, 1818, p. 553), perde sua coloração rosada - a qual retorna quando a solução é colocada em 
um quarto escuro. Os experimentos 220 e 221 descrevem sucessivas mudanças de cor de uma solução de óxido de níquel em amônia cáustica, pela exposição ao ar atmosférico, e pela adição sucessiva de um ácido e de mais amônia cáustica. Os experimentos 208 e 209 tratam, respectivamente, da cristalização de estanho em cristais romboidais, e de prata em prismas quadrangulares ou octaédricos. O experimento 223 retrata como uma mistura de cobre (descrito como um metal "amarelo") e antimônio ("um metal branco") fundidos resulta em uma liga de cor violeta (PARKES, 1818).

A última subcategoria que identificamos entre os Experimentos com os Metais reúne os experimentos 166, 199 e 211, que descrevem processos para a obtenção de diferentes compostos: muriato de chumbo, gás hidrogênio arsenuretado, e um composto roxo que Parkes disse antigamente se chamar cuprum amoniacum. O experimento 200 é uma continuação do experimento 199, e propõe que seja colocado fogo no gás hidrogênio arsenuretado obtido no experimento anterior para que, na presença de gás oxigênio, uma chama azul brilhante seja produzida (PARKES, 1818).

A décima e última categoria proposta por Parkes é denominada Experimentos Diversos. Nela identificamos apenas uma subcategoria, reunindo os experimentos 242, 243, 251, 253, 254 e 255, que abrangem a detecção de substâncias e análise de soluções (PARKES, 1818). Como exemplo, citamos o experimento 253:

253. Em um copo de água contendo uma pequena porção de sal comum, goteje um pouco de uma solução límpida de nitrato de prata, e um precipitado insolúvel de muriato de prata será produzido. Este experimento é projetado para dar ao aprendiz uma idéia do método para ANALISAR ÁGUAS MINERAIS. Cada 100 grãos desse precipitado, quando seco, indica 42 grãos de sal comum (PARKES, 1818, p. 561, destaque no original).

Os demais experimentos abordam fenômenos químicos diversos. Os experimentos 244 e 245 propõem exemplos de sublimação; o 246, a formação de 
um fluido por meio do atrito entre acetato de chumbo e o sulfato de zinco sólidos em um almofariz; o 247, a produção de sabão; o 248, a formação de ácido sulfúrico por meio da combustão de enxofre; o 249, a decomposição do ácido produzido no experimento anterior, pelo aquecimento com carvão; o 250, a emissão de luz pela reação química entre enxofre fundido e limalhas de cobre; e o 252, a observação da mudança da gravidade específica de um mesmo corpo (no caso, a água) pela ação do calórico (PARKES, 1818).

Os experimentos propostos por Parkes na lista de Seletos Experimentos Instrutivos, como pôde ser observado, são muito abrangentes, possuem diversas propostas e formatos, passando por diversos tipos de procedimentos e objetivos. Para efeito de nossa análise nesta dissertação, procuramos classificá-los em cinco categorias (diferentes das categorias utilizadas por Parkes), de acordo com seus objetivos e finalidades.

\subsubsection{A química experimental, entre o maravilhoso e o útil}

A primeira categoria pode ser definida como uma seleção de experimentos atrativos ou mesmo curiosos, fenômenos fantásticos e de execução interessante, que possuíam o intuito de fascinar o pupilo a ponto de provocar a sua mente para desvendar os conceitos por trás do experimento, o que era o principal motivo de Parkes ao propor a lista de experimentos, como indicado na introdução do capítulo Seletos Experimentos Instrutivos (PARKES, 1818). Como exemplo, destacamos um experimento que produz uma combustão dentro d'água:

118. Coloque um pouco de oximuriato de potássio e um pouco de fósforo em um copo de cerveja, e coloque um pouco de água gelada sobre eles com cautela, para não deslocar o sal. Agora pegue um pequeno tubo de vidro e o mergulhe em um pouco de ácido sulfúrico: então coloque o polegar sobre o orifício superior, e desse jeito retire o tubo, que deve ser instantaneamente imerso no copo [com a mistura anterior], de modo que, ao remover o polegar, o ácido possa ser imediatamente depositado sobre os ingredientes. Este experimento é um exemplo de um fenômeno muito 
singular, COMBUSTÃO EMBAIXO D'ÁGUA (PARKES, 1818, p. 541, destaque no original).

A segunda categoria consiste em uma seleção de experimentos em que Parkes demonstra fenômenos químicos específicos para que o leitor possa vir a ter um exemplo ou uma validação de um conceito ou fenômeno. Neles, no próprio enunciado, Parkes deixa claro que sua sugestão é um exemplo ou uma demonstração, utilizando expressões como "esse experimento proporcionará um exemplo de", "isso mostra como", "isso é ilustrativo de", como podemos observar no exemplo a seguir:

130. Coloque um pouco de álcool em uma xícara de chá, coloque fogo, e inverta um grande sino de vidro sobre ele. Em um curto espaço de tempo, um vapor aquoso será condensado no interior do sino, que, por meio de uma esponja seca, poderá ser coletado, e sua quantidade determinada. Isto pode ser apresentado como um exemplo da formação de ÁGUA POR COMBUSTÃO (PARKES, 1818, p. 543, destaque no original).

A terceira categoria de experimentos consiste em processos laboratoriais, ou seja, apresentação de técnicas importantes para a química e indústria. Nesta categoria foram considerados todos os experimentos que se referem explicitamente a um dado processo, que Parkes apresenta no próprio enunciado, e também os experimentos cuja aplicação fica implícita - como aqueles em que a precipitação pode ser usada para a detecção um dos reagentes envolvidos. Como exemplos, citamos a seguir o experimento que ensina como detectar ácidos voláteis e muriatos por meio de amônia, e também o experimento que origina um precipitado amarelo de nome não mencionado:

33. Sempre que o ácido muriático não combinado, ou qualquer ácido volátil, for suspeito de estar presente em alguma mistura química, ele pode 
ser detectado pela amônia. Uma única gota de amônia em uma pena, ou em uma pequena tira de papel, mantida sobre a mistura, tornará o VAPOR VISÍVEL imediatamente (PARKES, 1818, p. 528, destaque no original).

185. Se uma solução de tungstato de potassa for vertida em uma solução de sulfato de ferro verde, UM PRECIPITADO AMARELO se depositará. Por meio deste experimento, a característica distintiva deste metal é exibida (PARKES, 1818, p. 550, destaque no original).

Assim como nos experimentos das notas de rodapé, a quarta categoria presente entre os experimentos seletos se caracteriza pela produção de alguns compostos químicos mencionados durante a parte catequética da obra, ou reagentes que poderiam ser úteis em outros experimentos mais conceituais. Nesta categoria também podemos incluir todos os precipitados cujos nomes específicos foram citados por Parkes como o resultado da junção de duas soluções. Uma das produções que se pode destacar é a forma de se obter ácido carbônico gasoso (PARKES, 1818):

20. Coloque cerca de uma onça de mármore grosseiramente pulverizado em um frasco de oito onças, com aproximadamente uma quantidade igual de água. Despeje sobre ele um pouco de ácido sulfúrico, e ÁCIDO CARBÔNICO GASOSO irá se desprender (PARKES, 1818, p. 526, destaque no original).

A última categoria que propomos nesta análise reúne experimentos relacionados a alguma manufatura presente nas indústrias do Reino Unido. Alguns dos processos industriais descritos eram de imensa importância e interesse econômico para a época, como tingimento e branqueamento de tecidos, ou a aplicação de estampas em tecido calicô, um tecido de algodão fabricado na Índia 
que possuía grande apelo comercial na Inglaterra e que era importado pela Companhia das Índias Orientais ${ }^{11}$, seda e linho. Essa categoria remete prontamente a um dos primeiros objetivos apresentados por Parkes para escrever e publicar o Chemical Catechism: instruir os jovens para que melhor pudessem aplicar a química no aperfeiçoamento das atividades às quais viessem a se dedicar futuramente (PARKES, 1812; RIELLO, 2010). Como exemplo, apontamos um experimento que envolve a estampa em tecido calicô:

89. Mergulhe um pedaço de calicô branco em uma solução forte de acetato de ferro; seque-o junto ao fogo e deixe-o de lado por três ou quatro dias. Depois disso, lave-o bem com água quente e depois tinja-o de preto, fazendo-o ferver por dez minutos em uma forte decocção de madeira do Brasil. Se o pano for então seco, quaisquer figuras impressas sobre ele com uma solução incolor de muriato de estanho aparecerão em um BONITO ESCARLATE, embora o fundo continue como um PRETO permanente (PARKES, 1818, p. 536-537, destaque no original).

Os números dos experimentos que podem ser classificados em cada uma dessas categorias se encontram na Tabela 2:

Tabela 2 - Classificação dos experimentos de acordo com as categorias propostas.

\begin{tabular}{|c|c|}
\hline Categoria & Número do experimento \\
\hline I. Fenômenos atrativos ou & $1,2,3,6,7,8,10,13,15,19,36,37,38,39,41$, \\
\hline
\end{tabular}

${ }^{11}$ A Companhia das Índias Orientais atuava no comércio entre a Inglaterra e as Índias Orientais. Segundo Bowen (2008), no começo no século XIX, ela contribuiu para o fortalecimento da Grã-Bretanha dentro e fora do Reino, exercendo papel importantíssimo para o comércio. De acordo com Cutler (1976), uma quantidade considerável dos financiadores da Royal Institution que priorizavam as atividades mercantis tinham relação com a Companhia das Índias Orientais. 


\begin{tabular}{|c|c|}
\hline curiosos & $\begin{array}{l}42,54,56,79,80,81,97,99,100,101,102, \\
103,105,106,107,108,109,112,113,114, \\
115,116,117,118,119,120,122,123,124, \\
125,126,128,129,136,137,138,139,140, \\
141,142,143,144,145,146,147,148,149, \\
170,171,177,200,201,202,210,220,221, \\
223,224,246,250 .\end{array}$ \\
\hline $\begin{array}{ll}\text { II. Demonstração } & \text { de um } \\
\text { fenômeno } & \text { químico } \\
\text { específico } & \end{array}$ & $\begin{array}{l}4,5,9,11,12,14,16,17,18,35,43,44,45,46, \\
47,48,49,50,51,52,57,58,59,60,104,110, \\
121,127,130,133,168,169,175,180,193, \\
195,196,197,203,205,206,207,244,245, \\
248,249,252 .\end{array}$ \\
\hline III. Processos laboratoriais & $\begin{array}{l}33,34,61,62,63,64,65,66,67,68,69,70,71, \\
72,73,74,75,76,77,78,158,165,173,174, \\
178,179,181,182,183,184,185,191,194, \\
198,204,208,209,216,217,222,241,242, \\
243,251,253,254,255 .\end{array}$ \\
\hline $\begin{array}{l}\text { IV. Produção ou obtenção } \\
\text { de uma substância }\end{array}$ & $\begin{array}{l}20,21,22,23,24,25,26,27,28,29,30,31,32, \\
53,55,98,111,131,132,134,135,150,151, \\
152,153,154,155,156,157,159,160,161, \\
162,163,164,166,167,172,176,192,199, \\
211,212,213,214,215,225,226 .\end{array}$ \\
\hline $\begin{array}{l}\text { V. Processos relacionados } \\
\text { a manufaturas }\end{array}$ & $\begin{array}{l}\text { 40, 82, 83, 84, 85, 86, 87, 88, 89, 90, 91, 92, 93, } \\
94,95,96,186,187,188,189,190,218,219, \\
227,228,229,230,231,232,233,234,235, \\
236,237,238,239,240,247 .\end{array}$ \\
\hline
\end{tabular}

Tal como nas notas de rodapé, muitos dos experimentos presentes no capítulo "Seletos experimentos instrutivos" necessitam de, ou produzem, substâncias perigosas, nocivas para a saúde ou mesmo facilmente inflamáveis, assim como também provocam reações explosivas e arriscadas, que certamente não deveriam ser recomendadas a experimentadores inexperientes. Com o passar 
das edições, alguns avisos de segurança foram adicionados, como o encontrado no experimento de número 55 na primeira edição e 60 na segunda, que citamos a seguir:

55. Pegue três partes de nitro [salitre], duas de potassa e uma de enxofre; faça-os secar completamente e depois misture-os, triturando-os em um almofariz aquecido. O composto resultante é chamado de pó fulminante. Se um pouco desse pó for colocado em uma pá de lareira sobre um fogo quente, ele gradualmente escurece e finalmente derrete. Nesse instante, EXPLODE COM UM VIOLENTO RUMOR (PARKES, 1807b, p. 298, destaque no original).

60. Pegue três partes de nitro, duas de potassa e uma de enxofre; todos estes devem estar completamente secos; em seguida misture-os triturando-os juntos em um almofariz aquecido: o composto resultante é chamado de pó fulminante. Se um pouco desse pó for colocado em uma pá de lareira sobre um fogo quente, ele gradualmente escurece, e finalmente derrete. Nesse instante, ele EXPLODE COM UM VIOLENTO RUMOR. Nota, Esta mistura não é perigosa, como os pós fulminantes metálicos; nenhum dos quais deve ser confiado nas mãos dos jovens (PARKES, 1807a, p. 557, destaque no original).

Porém, mesmo com as adições, os alertas de periculosidade são muito poucos, se comparados ao número de experimentos perigosos. Essa falta de avisos de segurança e alertas de risco é alarmante aos olhos modernos, mas também despertou críticas dos próprios contemporâneos - ainda que Parkes afirmasse, no começo do capítulo, que as experiências ali apresentadas foram escolhidas por serem passíveis de realização com "facilidade e segurança" (PARKES, 1812, p. 475). 


\section{Considerações finais}

A ciência pode se tornar pública de diversas maneiras diferentes. Seja por meio de palestras, demonstrações, publicações periódicas ou mesmo livros introdutórios, a divulgação exerce um papel fundamental na aproximação da ciência com o público em geral. Na Inglaterra do século XIX, período em que expressivas parcelas da população viam a ciência como um assunto deveras interessante, livros de divulgação da ciência se prestavam bem a esse papel de aproximação, ao servirem como intermediários para a comunicação do conhecimento científico para o público, sem a ambição de formar especialistas em ciência com o seu conteúdo (GOLINSKI, 1999; KNIGHT, 2002).

Nesta dissertação, buscamos primeiramente caracterizar os variados termos que são adotados na literatura para retratar situações nas quais a difusão da ciência acontece, e ponderar qual dos termos seria adotado e utilizado em nosso texto. Em seguida, investigamos o contexto histórico do começo do século XIX, e os possíveis motivos que levaram a população da Inglaterra a ver a ciência como um conhecimento extremamente importante e divertido, atraindo massas de diferentes procedências a se juntarem para contemplar e admirar as maravilhas da ciência, assim como consumir literatura científica (KNIGHT, 2002).

No âmbito da literatura de divulgação científica, um livro que se destacou pelo seu sucesso comercial dentro e fora do Reino Unido foi o Chemical Catechism, de Samuel Parkes, uma obra introdutória à química redigida no formato de catecismo, ou seja, de perguntas e respostas, acompanhadas por extensas notas de rodapé repletas de diversas informações interessantes. Essas notas contextualizam de forma distinta a cultura, história, moral e evolução da ciência na época, assim como sugerem experimentos e demonstrações químicas com o objetivo de instigar as jovens mentes dos aprendizes ao interesse pela ciência (KNIGHT, 2002; KURZER, 1997; PARKES, 1807a).

Os experimentos do Chemical Catechism possuíam diferentes objetivos, dependendo do lugar e da forma em que eram colocados, oferecendo atrativos de caráter sensorial, científico e industrial, e buscando comprovar, validar e demonstrar 
os pontos principais dos conceitos químicos apresentados no texto catequético da obra. Nesta dissertação, procuramos analisar a apresentação dos diversos experimentos apresentados por Parkes, considerando sua forma e seus objetivos.

A dimensão experimental da ciência pode ser apontada como uma das maiores preocupações de Parkes ao escrever o Chemical Catechism, já que ele não apenas sugeriu experimentos nas notas de rodapé ao longo dos capítulos principais, mas também dedicou uma seção completa de seu livro para eles. Os experimentos sugeridos tinham objetivos diferentes: convencer o pupilo fornecendo validações acerca do que lhe era apontado na parte catequética do livro, introduzir processos laboratoriais, produzir substâncias, maravilhar o aprendiz com fenômenos atrativos ou curiosos e introduzir processos referentes à manufatura.

A análise dos experimentos nos revela, de certa forma, como Parkes pensava a química e sua divulgação. Em primeiro lugar, era preciso atrair a atenção dos aprendizes, para que eles se interessassem pelo que os químicos têm a dizer - para isso, nada melhor do que maravilhá-los com os experimentos e demonstrações que apelavam aos sentidos, por meio de explosões, chamas, cores, odores, fenômenos inusitados, o que também deveria servir como apelo afetivo. Uma vez que a atenção fora ganha, era preciso deixar claro do que se estava falando, ou seja, do que trata a química. Daí a importância dos experimentos que demonstravam os fenômenos ou "comprovavam" as explicações propostas. Também era necessário que os aprendizes entendessem como os químicos trabalham, quais seus aparelhos e procedimentos, para que os aprendizes também pudessem fazer como eles - se não enquanto jovens, talvez no exercício de suas futuras atividades profissionais. Para que isso fosse possível, Parkes dedicou muitos experimentos à apresentação de técnicas e processos de laboratório. Nesse sentido também podem ser entendidos os experimentos dedicados à preparação de substâncias, que fornecem as matérias-primas com as quais os químicos trabalham, ou que os químicos fornecem a outros profissionais para uso em suas manufaturas e processos. Entende-se, então, o papel dos experimentos que demonstravam processos ligados à manufatura: a produção de coisas úteis justifica e serve como um coroamento para o aprendizado da química, pois conduz ao benefício da nação e à prosperidade pessoal. Pode-se imaginar que, em certo sentido, Parkes projetava nesses 
experimentos sua própria trajetória pessoal: ele se salvou da falência, amealhou fortuna e fama produzindo e vendendo produtos químicos.

Por ser dirigido a crianças e aprendizes supostamente leigos na ciência, e considerando que Parkes não esconde sua pretensão de que o Chemical Catechism fosse usado como introdução à química, é quase inevitável que o estudo dessa obra nos faça refletir sobre a divulgação da ciência também na atualidade. É evidente que as condições são completamente diferentes, especialmente em relação aos recursos hoje disponíveis para a comunicação e a divulgação do conhecimento. Entretanto, talvez as abordagens e características subjacentes ao Chemical Catechism possam gerar reflexões úteis para os interessados na divulgação da química nos dias atuais.

A evolução e atualização do conteúdo científico do Chemical Catechism conforme novas edições iam sendo lançadas nos ajuda a caracterizar o aspecto mutável da ciência. A análise dos experimentos propostos e suas relações com o contexto da época pode vir a inspirar o leitor a refletir sobre as estratégias de abordagem experimentais com relação aos interesses comuns, culturais e econômicos presentes na sociedade. Para um entendimento inicial do que trata a química, a apresentação de substâncias e suas transformações continua a ser uma estratégia interessante, e o apelo sensorial ainda pode ser um poderoso instrumento para o envolvimento afetivo - ainda que, muito provavelmente, não de maneira tão dramática como no século XIX. Além disso, os padrões atuais de segurança colocam - felizmente - limitações àquilo que pode ser levado à presença do público. A progressiva transformação da química em ciência dos átomos e moléculas impede que sua divulgação se limite aos fenômenos macroscópicos. A necessidade de apresentar explicações em termos de partículas submicroscópicas se apresenta como um desafio para os divulgadores contemporâneos da química; provavelmente, um desafio maior do que tornar compreensíveis as explicações em termos de um imponderável calórico com que se defrontava Parkes.

O Chemical Catechism e seu contexto também podem nos ensinar que a soberania de uma nação passa pelo bom aproveitamento de seus recursos naturais para seu progresso e bem estar de sua população, e a química desempenha um papel fundamental nesse cenário. Para que lições como essa sejam aprendidas no 
século XXI, cabe-nos, cada vez mais, combater a ignorância e a desinformação - e não apenas sobre a ciência. 


\section{Referências}

ALFONSO-GOLDFARB, A. M.; BELTRAN, M. H. R. Escrevendo a história da ciência: tendências, propostas e discussões historiográficas. São Paulo: Editora Livraria da Física, 2004.

ANÔNIMO. The Chemical Catechism. By Samuel Parkes, Manufacturing Chemist. Bvo. Published by Symonds. Price 12 s. 624 Pages. In: TILLOCH, Alexander (Ed.). The Philosophical Magazine: comprehending the various branches of science, the liberal and fine arts, agriculture, manufactures, and commerce. Londres: R. Taylor And Co., 1806. p. 7681. v. 25.

ANÔNIMO. A Chemical Catechism for the Use of Young People, with copious Notes for the Assistance of the Teacher; to which are added a Vocabulary, useful Tables, and a Chapter of amusing Experiments: By S. Parkes, Manufacturing Chemist. Pp. 624. 8vo. Symonds. 12s, boards. In: ANÔNIMO. The Anti-Jacobin Review and Magazine. Londres: Knight And Compton, Cloth Fair, 1807a. p. 19-27. v. 27.

ANÔNIMO. Art. X. A Chemical Catechism for the Use of Young People, with copious Notes for the Assistance of the Teacher; to which are added a Vocabulary, useful Tables, and a Chapter of amusing Experiments. By S. Parkes, Manufacturing Chemist. 8vo. 12s. Boards. Symonds, \&c. 1806. In: ANÔNIMO. The Monthly Review; or literary journal. Londres: T. Becket, Bookseller, In Pall Mall, 1807. p. 64-67. v. 53.

ANÔNIMO. A Chemical Catechism. In: URBAN, Sylvanus (Ed.). The Gentleman's Magazine and Historical Chronicle. Londres: John Nichols And Son, 1807. p. $143-145$. v. 77.

ANÔNIMO. Surrey Institution. In: ANÔNIMO. The New Monthly Magazine and Literary Journal. Londres: S. And R. Bentley, 1823a. p. 16. v. 4.

ANÔNIMO. Times's Telescope for 1824. In: URBAN, Sylvanus. The Gentlman's 
Magazine: and Historical Chronicle. Londres: John Nichols And Son, 1823b. p. 524-528. v. 93.

ANÔNIMO. Monday 23 April 1877. The Islington Gazette, p. 1, 1877.

BALDINATO, J. O. Conhecendo a Química: Um estudo sobre obras de divulgação do início do século XIX. 2015. 169 f. Tese (Doutorado em Ensino de Ciências), Universidade de São Paulo, São Paulo, 2015.

BELTRAN, M. H. R. História da Ciência para formação de professores. São Paulo: Editora Livraria da Física, 2014.

BLAIR, R. D. A Grammar of Chemistry. Hartford: S. G. Goodrich, 1822.

BOWEN, H. V. The Business of Empire: The East India Company and Imperial Britain, 1756-1833. $1^{\text {a }}$ ed. Cambridge: Cambridge University Press, 2008.

BRASIL, Ministério da Educação. Parâmetros Curriculares Nacionais: Ensino Médio. Brasília: MEC, 2000.

BRASIL, Ministério da Educação. Base Nacional Comum Curricular. Brasília: MEC, 2018.

CHAPPEY, J. Enjeux sociaux et politiques de la "vulgarisation scientifique » en Révolution (1780-1810). Annales historiques de la Révolution française, v. 338, n. 4, p. 1, 2004.

CROOKES, W. (ED.). The chemical news and journal of physical science. A journal of practical Chemistry in all its applications to pharmacy, arts, and manufactures. London: Henry Gillman, Boy Court, Ludgate Hill, E.C., 1873.

CUTLER, J. C. The London Institution 1805-1933. Leicester: University of Leicester, 1976.

ESTRADA, L. La divulgación de la Ciencia. Ciencias, v. 27, p. 69-76, 1992.

GERMANO, M. G.; KULESZA, W. A. Popularização da ciência: uma revisão 
conceitual. Caderno Brasileiro de Ensino de Física, v. 24, p. 7-25, 2007.

GOLINSKI, J. Science as Public Culture: Chemistry and Enlightenment in Britain, 1760-1820. Cambridge: Cambridge University Press, 1999.

HINDLEY, C. An Address, delivered at the establishment of the Mechanics' Institution, Ashton-under-Lyne. Edinburgh Review, v. 42, n. 2, p. 499$504,1825$.

HIRA, N.; LEWIS, F. W. Silver Nitrate "Foreign Body". British Medical Journal, n. March, p. 693, 1970.

HODGETTS, J. W. Obituary. The Monthly Repository of Theology and General Literature, v. XXI, p. 120-121, 1826.

HOLLAND, H. Recollections of past life. Nova York: D. Appleton and company, 1872.

JAMES, F. A. J. L.; PEERS, A. Constructing space for science at the Royal Institution of Great Britain. Physics in Perspective, v. 9, n. 2, p. 130-185, 2007.

KNIGHT, D. Accomplishment or Dogma: Chemistry in the Introductory Works of Jane Marcet and Samuel Parkes. Ambix, v. 33, n. 2, p. 94-98, 1986.

KNIGHT, D. Scientists and Their Publics: Popularization of Science in the Nineteenth Century. In: The Cambridge History of Science Volume 5: The Modern Physical and Mathematical Sciences. Cambridge: Cambridge University Press, 2002. v. 5. p. 72-90.

KNIGHT, D. ESSAY Popularizing Chemistry: Hands-on and Hands-off. Hyle, v. 12, n. 1, p. 131-140, 2006.

KNIGHT, D. Popularizing Chemistry: Hands-on and Hands-off. In: SCHUMMER, J. BENSAUDE-VINCENT, B. TIGGELEN, B. V. (Eds.) The Public Image of Chemistry. Singapura: World Scientific Publishing, 2007. p. 123-136.

KNIGHT, D. Communicating chemistry: the frontier between Popular Books and 
Textbooks in Britain during the First Half of the Nineteenth Century. In: LUNDGREN, A.; BENSAUDE-VINCENT, B. (Eds.). Communicating Chemistry: textbooks and their audiences 1789-1939. Canton: Science History Publications, 2009. v. 1, p. 673-678.

KRAMNICK, I. Eighteenth-Century Science and Radical Social Theory: The Case of Joseph Priestley's Scientific Liberalism. The Journal of British Studies, v. 25, n. 1 , p. $1-30,1986$.

KURZER, F. Samuel Parkes: Chemist, author, reformer-A biography. Annals of Science, v. 54, n. 5, p. 431-462, set. 1997.

KURZER, F. A History of the Surrey Institution. Annals of Science, v. 57, n. 2, p. 109-141, 2000.

LAVOISIER, A. L. Tratado Elementar da Química: Apresentado em uma ordem nova e segundo as descobertas modernas. Tradução LSP Trindade. São Paulo: Madras, 2007.

LIGHTMAN, B. Victorian Science in Context. Chicago and London: University of Chicago Press, 1997.

LIGHTMAN, B. Historians, popularizers, and the Victorian Scene. In: Victorian Popularizers of Science: Designing Nature for New Audiences. Chicago and London: The University of Chicago Press, 2007. p. 1-38.

LONDON INSTITUTION. A Catalogue of the Library of the London Institution: systematically classed. Londres: Não Publicado, 1835. v. I

MASSARANI, L. A divulgação científica no Rio de Janeiro: Algumas reflexões sobre a década de 20. Rio de Janeiro: UFRJ, 1998.

MCLACHLAN, H. English education under the test acts: being the history of the non-conformist academies 1662-1820. Manchester: Manchester University Press, 1931.

NATIONAL OCEANIC AND ATMOSPHERIC ADMINISTRATION. Hydrochloric Acid. Disponível em: <https://cameochemicals.noaa.gov/chris/HCL.pdf>. 
Acesso em: 29 out. 2017 a.

NATIONAL OCEANIC AND ATMOSPHERIC ADMINISTRATION. Chlorine. Disponível em: <https://cameochemicals.noaa.gov/chris/CLX.pdf>. Acesso em: 29 out. $2017 \mathrm{~b}$.

PALEY, W. Natural theology. Nova York: Oxford University Press, 2006.

PARKES, S. A Chemical Catechism with copious notes, a vocabulary of chemical terms, useful tables, and a chapter of instructive and amusing experiments. 2 ed. London: Lackington, Allen, and Co., 1807a.

PARKES, S. Chymical Catechism: application of chymistry to the arts, for the use of young people, artists, tradesmen and the amusement of leisure hours to which are added a vocabulary of chymical terms, some useful tables and a variety of amusing experiments. $1 \mathrm{ed}$. Philadelphia: James Humphreys, 1807b.

PARKES, S. The Chemical Catechism, with notes, illustrations and experiments. 3 ed. London: Lackington, Allen and Co, 1808.

PARKES, S. The chemical catechism: with notes, illustrations and experiments. 4 ed. London: Lackington, 1810.

PARKES, S. The Chemical Catechism with notes, illustrations, and experiments. 5 ed. London: Lackington, Allen, and Co., 1812.

PARKES, S. The Chemical Catechism, with notes, illustrations and experiments. 6 ed. London: Lackington, Allen and Co, 1814.

PARKES, S. The Chemical Catechism, with notes, illustrations and experiments. 8 ed. Londres: Baldwin, Cradock and Joy, Paternoster-row, 1818.

PARKES, S. The Chemical Catechism with notes, illustrations and experiments. 9 ed. London: Baldwin, Cradock, and Joy, 1819.

PARKES, S. The Chemical Catechism, with tables, notes, illustrations and 
experiments. 10 ed. London: Baldwin, Cradock, and Joy, 1822.

PARKES, S. The Chemical Catechism, with tables, notes, illustrations, and experiments. 11 ed. London: Baldwin, Cradock and Joy, 1824.

PARKES, S. The Rudiments of Chemistry. 4 ed. Londres: Baldwin, Cradock and Joy, 1826a.

PARKES, S. The Chemical Catechism. 12 ed. London: Baldwin, Cradock and Joy, Paternoster-row, 1826b.

PARKES, S. The Chemical Catechism. 13 ed. London: Longman, Rees, Orme, Brown, Green and Longman, 1834.

PARKES, S. Catechism of Chemistry. Londres: Scott, Webster and Geary, charterhouse square, 1837.

PARKES, S. A Catechism of Chemistry: with an appendix of experiments, a vocabulary of chemical terms and indez. Londres: Adam Scott, Charterhouse square, 1854.

RIELLO, G. Asian knowledge and the development of calico printing in Europe in the seventeenth and eighteenth centuries. Journal of Global History, v. 5, n. London School of Economics and Political Science, p. 1-28, 2010.

RUSSELL, E. War and Nature: Fighting Humans and Insects with Chemicals from World War I to Silent Spring. 1 ed. Cambridge: Cambridge University Press, 2001.

SIEGEL, S. First Exposures: writings from the beginning of photography. $1 \mathrm{ed}$. Los Angeles: J. Paul Getty Museum, 2017.

SILLIMAN, B. A journal of travels in England, Holland, and Scotland and of two passages ovre the atlantic in the years 1805 and 1806 in two volumes. 2 ed. Boston: T. B. Wait and co., 1812.

SILVA, R. M. I. E. O encontro da química e da religião na obra de Samuel Parkes. Monografia (Licenciatura em Química), São Paulo: IFSP - Insituto 
Federal de Educação, Ciência e Tecnologia de São Paulo, 2015.

THOMSON, T. A system of chemistry. 2nd ed. Edinburgh: Bell \& Bradfute, 1804.

TOPHAM, J. R. Beyond the "Common Context": The Production and Reading of the Bridgewater Treatises. Isis, v. 89, n. 2, p. 233-262, 1998.

TOPHAM, J. R. Scientific publishing and the reading of science in nineteenth-century Britain: a historiographical survey and guide to sources. Studies In History and Philosophy of Science Part A, v. 31, n. 4, p. 559-612, 2000.

TOPHAM, J. R. Rethinking the History of Science Popularization/Popular Science. In: NIETO-GALAN, A.; PERDIGUERO, E. (Eds.). Popularizing Science and Technology in the European Periphery, 1800-2000. Farnham: Ashgate, 2009. p. 1-20.

URE, A. A Dictionary of Chemistry. 1 ed. Philadelphia: Robert Desilver, 1821.

WATKINS, J.; SHOBERL, F.; UPCOTT, W. A Biographical Dictionary of the Living Authors of Great Britain and Ireland: Comprising Literary Memoirs and Anecdotes of Their Lives, and a Chronological Register of Their Publications, with the Number of Editions Printed; Including Notices of Some Fore. Londres: Henry Colburn, 1816. 


\section{Apêndice:}

Tabela comparativa de doze edições do Chemical Catechism. Cada linha corresponde a um mesmo experimento, e a tabela mostra a numeração que o experimento recebeu em cada edição.

\begin{tabular}{|c|c|c|c|c|c|c|c|c|c|c|c|c|}
\hline Ed. & $1^{\mathrm{a}}$ & $2^{\mathrm{a}}$ & $3^{\underline{a}}$ & $4^{\underline{a}}$ & $5^{\mathbf{a}}$ & $6^{\underline{a}}$ & $8^{\mathrm{a}}$ & $9^{a}$ & $10^{\mathrm{a}}$ & $11^{\mathrm{a}}$ & $12^{a}$ & $13^{\mathrm{a}}$ \\
\hline Ano & 1807 & 1807 & 1808 & 1810 & 1812 & 1814 & 1818 & 1819 & 1822 & 1824 & 1826 & 1834 \\
\hline & 1 & 1 & 1 & 1 & 1 & 1 & 1 & 1 & 1 & 1 & 1 & 1 \\
\hline & 2 & 2 & 2 & 2 & 2 & 2 & 2 & 2 & 2 & 2 & 2 & 2 \\
\hline & 3 & 3 & 3 & 3 & 3 & 3 & 108 & 108 & 108 & 108 & 108 & 105 \\
\hline & 4 & 4 & 4 & 4 & 4 & 4 & 20 & 20 & 20 & 20 & 20 & 19 \\
\hline & 5 & 5 & 5 & 5 & 5 & 5 & 21 & 21 & 21 & 21 & 21 & 20 \\
\hline & 6 & 6 & 6 & 6 & 6 & 6 & 22 & 22 & 22 & 22 & 22 & 21 \\
\hline & 7 & 7 & 7 & 7 & 7 & 7 & 23 & 23 & 23 & 23 & 23 & 23 \\
\hline & 8 & 8 & 8 & 8 & 8 & 8 & 24 & 24 & 24 & 24 & 24 & 23 \\
\hline & 9 & 9 & 9 & 9 & 9 & 9 & 26 & 26 & 26 & 26 & 26 & 25 \\
\hline & 10 & 10 & 10 & 10 & 10 & 10 & 27 & 27 & 27 & 27 & 27 & 26 \\
\hline & 11 & 11 & 11 & 11 & 11 & 11 & 28 & 28 & 28 & 28 & 28 & 27 \\
\hline & 12 & 12 & 12 & 12 & 12 & 12 & 29 & 29 & 29 & 29 & 29 & 28 \\
\hline$\stackrel{\mathbb{T}}{\Phi}$ & 13 & 13 & 13 & 13 & 13 & 13 & 30 & 30 & 30 & 30 & 30 & 29 \\
\hline & 14 & 14 & 14 & 14 & 14 & 14 & 31 & 31 & 31 & 31 & 31 & 30 \\
\hline ய & 15 & 15 & 15 & 15 & 15 & 15 & 32 & 32 & 32 & 32 & 32 & 31 \\
\hline & - & 16 & 16 & 16 & 16 & 16 & 46 & 46 & 46 & 46 & 46 & 44 \\
\hline & - & 17 & 17 & 17 & 17 & 17 & 47 & 47 & 47 & 47 & 47 & 45 \\
\hline & - & 18 & 18 & 18 & 18 & 18 & 48 & 48 & 48 & 48 & 48 & 46 \\
\hline & 16 & 19 & 19 & 19 & 19 & 19 & 49 & 49 & 49 & 49 & 49 & 47 \\
\hline & 17 & 20 & 20 & 20 & 20 & 20 & 50 & 50 & 50 & 50 & 50 & 48 \\
\hline & 18 & 21 & 21 & 21 & 21 & 21 & 51 & 51 & 51 & 51 & 51 & 49 \\
\hline & - & 22 & 22 & 22 & 22 & 22 & 52 & 52 & 52 & 52 & 52 & 50 \\
\hline & 19 & 23 & 23 & 23 & 23 & 23 & 53 & 53 & 53 & 53 & 53 & 51 \\
\hline & 20 & 24 & 24 & 24 & 24 & 24 & 54 & 54 & 54 & 54 & 54 & 52 \\
\hline & 21 & 25 & 25 & 25 & 25 & 25 & 55 & 55 & 55 & 55 & 55 & 53 \\
\hline & 22 & 26 & 26 & 26 & 26 & 26 & 56 & 56 & 56 & 56 & 56 & 54 \\
\hline
\end{tabular}




\begin{tabular}{|c|c|c|c|c|c|c|c|c|c|c|c|}
\hline 23 & 27 & 27 & 27 & 27 & 27 & 57 & 57 & 57 & 57 & 57 & 55 \\
\hline 24 & 28 & 28 & 28 & 28 & 28 & 58 & 58 & 58 & 58 & 58 & 56 \\
\hline 25 & 29 & 29 & 29 & 29 & 29 & - & - & - & - & - & - \\
\hline 26 & 30 & 30 & 30 & 30 & 30 & 109 & 109 & 109 & 109 & 109 & 106 \\
\hline 27 & 31 & 31 & 31 & 31 & 31 & 110 & 110 & 110 & 110 & 110 & 107 \\
\hline 28 & 32 & 32 & 32 & 32 & 32 & 111 & 111 & 111 & 111 & 111 & 108 \\
\hline 29 & 33 & 33 & 33 & 33 & 33 & 112 & 112 & 112 & 112 & 112 & 109 \\
\hline 30 & 34 & 34 & 34 & 34 & 34 & 113 & 113 & 113 & 113 & 113 & 110 \\
\hline 31 & 35 & 35 & 35 & 35 & 35 & 114 & 114 & 114 & 114 & 114 & 111 \\
\hline 32 & 36 & 36 & 36 & 36 & 36 & 115 & 115 & 115 & 115 & 115 & 112 \\
\hline 33 & 37 & 37 & 37 & 37 & 37 & 116 & 116 & 116 & 116 & 116 & 113 \\
\hline- & 38 & 38 & 38 & 38 & 38 & 117 & 117 & 117 & 117 & 117 & 114 \\
\hline 34 & 39 & 39 & 39 & 39 & 39 & 118 & 118 & 118 & 118 & 118 & 115 \\
\hline 35 & 40 & 40 & 40 & 40 & 40 & 119 & 119 & 119 & 119 & 119 & 116 \\
\hline 36 & 41 & 41 & 41 & 41 & 41 & 120 & 120 & 120 & 120 & 120 & 117 \\
\hline 37 & 42 & 42 & 42 & 42 & 42 & 121 & 121 & 121 & 121 & 121 & - \\
\hline 38 & 43 & 43 & 43 & 43 & 43 & 59 & 59 & 59 & 59 & 59 & 57 \\
\hline 39 & 44 & 44 & 44 & 44 & 44 & 60 & 60 & 60 & 60 & 60 & 58 \\
\hline 40 & 45 & 45 & 45 & 45 & 45 & 61 & 61 & 61 & 61 & 61 & 59 \\
\hline 41 & 46 & 46 & 46 & 46 & 46 & 62 & 62 & 62 & 62 & 62 & 60 \\
\hline 42 & 47 & 47 & 47 & 47 & 47 & 63 & 63 & 63 & 63 & 63 & 61 \\
\hline 43 & 48 & 48 & 48 & 48 & 48 & 64 & 64 & 64 & 64 & 64 & 62 \\
\hline 44 & 49 & 49 & 49 & 49 & 49 & 65 & 65 & 65 & 65 & 65 & 63 \\
\hline 45 & 50 & 50 & 50 & 50 & 50 & 66 & 66 & 66 & 66 & 66 & 64 \\
\hline 46 & 51 & 51 & 51 & 51 & 51 & 67 & 67 & 67 & 67 & 67 & 65 \\
\hline 47 & 52 & 52 & 52 & 52 & 52 & 68 & 68 & 68 & 68 & 68 & 66 \\
\hline 48 & 53 & 53 & 53 & 53 & 53 & 69 & 69 & 69 & 69 & 69 & 67 \\
\hline 49 & 54 & 54 & 54 & 54 & 54 & 70 & 70 & 70 & 70 & 70 & 68 \\
\hline 50 & 55 & 55 & 55 & 55 & 55 & 71 & 71 & 71 & 71 & 71 & 69 \\
\hline 51 & 56 & 56 & 56 & 56 & 56 & 72 & 72 & 72 & 72 & 72 & 70 \\
\hline 52 & 57 & 57 & 57 & 57 & 57 & 73 & 73 & 73 & 73 & 73 & 71 \\
\hline 53 & 58 & 58 & 58 & 58 & 58 & 74 & 74 & 74 & 74 & 74 & 72 \\
\hline
\end{tabular}




\begin{tabular}{|c|c|c|c|c|c|c|c|c|c|c|c|}
\hline 54 & 59 & 59 & 59 & 59 & 59 & 97 & 97 & 97 & 97 & 97 & 95 \\
\hline 55 & 60 & 60 & 60 & 60 & 60 & 98 & 98 & 98 & 98 & 98 & 98 \\
\hline 56 & 61 & 61 & 61 & 61 & 61 & 33 & 33 & 33 & 33 & 33 & 32 \\
\hline 57 & 62 & 62 & 62 & 62 & 62 & 34 & 34 & 34 & 34 & 34 & 33 \\
\hline 58 & 63 & 63 & 63 & 63 & 63 & 35 & 35 & 35 & 35 & 35 & 34 \\
\hline 59 & 64 & 64 & 64 & 64 & 64 & 36 & 36 & 36 & 36 & 36 & 35 \\
\hline 60 & 65 & 65 & 65 & 65 & 65 & 37 & 37 & 37 & 37 & 37 & 36 \\
\hline 61 & 66 & 66 & 66 & 66 & 66 & 38 & 38 & 38 & 38 & 38 & 37 \\
\hline 62 & 67 & 67 & 67 & 67 & 67 & 150 & 150 & 150 & 150 & 150 & 145 \\
\hline 63 & 68 & 68 & 68 & 68 & 68 & 151 & 151 & 151 & 151 & 151 & 146 \\
\hline 64 & 69 & 69 & 69 & 69 & 69 & 152 & 152 & 152 & 152 & 152 & 147 \\
\hline 65 & 70 & 70 & 70 & 70 & 70 & 153 & 153 & 153 & 153 & 153 & 148 \\
\hline 66 & 71 & 71 & 71 & 71 & 71 & 154 & 154 & 154 & 154 & 154 & 149 \\
\hline 67 & 72 & 72 & 72 & 72 & 72 & 155 & 155 & 155 & 155 & 155 & 150 \\
\hline 68 & 73 & 73 & 73 & 73 & 73 & 156 & 156 & 156 & 156 & 156 & 151 \\
\hline 69 & 74 & 74 & 74 & 74 & 74 & 157 & 157 & 157 & 157 & 157 & 152 \\
\hline 70 & 75 & 75 & 75 & 75 & 75 & 158 & 158 & 158 & 158 & 158 & 153 \\
\hline 71 & 76 & 76 & 76 & 76 & 76 & 159 & 159 & 159 & 159 & 159 & 154 \\
\hline 72 & 77 & 77 & 77 & 77 & 77 & 160 & 160 & 160 & 160 & 160 & 155 \\
\hline 73 & 78 & 78 & 78 & 78 & 78 & 162 & 162 & 162 & 162 & 162 & - \\
\hline 74 & 79 & 79 & 79 & 79 & 79 & 163 & 163 & 163 & 163 & 163 & 157 \\
\hline 75 & 80 & 80 & 80 & 80 & 80 & 164 & 164 & 164 & 164 & 164 & 158 \\
\hline 76 & 81 & 81 & 81 & 81 & 81 & 165 & 165 & 165 & 165 & 165 & - \\
\hline 77 & 82 & 82 & 82 & 82 & 82 & 166 & 166 & 166 & 166 & 166 & 159 \\
\hline 78 & 83 & 83 & 83 & 83 & 83 & 167 & 167 & 167 & 167 & 167 & 160 \\
\hline 79 & 84 & 84 & 84 & 84 & 84 & 168 & 168 & 168 & 168 & 168 & 161 \\
\hline 80 & 85 & 85 & 85 & 85 & 85 & 84 & 84 & 84 & 84 & 84 & 82 \\
\hline 81 & 86 & 86 & 86 & 86 & 86 & 85 & 85 & 85 & 85 & 85 & 83 \\
\hline 82 & 87 & 87 & 87 & 87 & 87 & 86 & 86 & 86 & 86 & 86 & 84 \\
\hline 83 & 88 & 88 & 88 & 88 & 88 & 87 & 87 & 87 & 87 & 87 & 85 \\
\hline 84 & 89 & 89 & 89 & 89 & 89 & 88 & 88 & 88 & 88 & 88 & 86 \\
\hline- & 90 & 90 & 90 & 90 & 90 & 89 & 89 & 89 & 89 & 89 & 87 \\
\hline
\end{tabular}




\begin{tabular}{|c|c|c|c|c|c|c|c|c|c|c|c|}
\hline- & 91 & 91 & 91 & 91 & 91 & 90 & 90 & 90 & 90 & 90 & 88 \\
\hline 85 & 92 & 92 & 92 & 92 & 92 & 91 & 91 & 91 & 91 & 91 & 89 \\
\hline 86 & 93 & 93 & 93 & 93 & 93 & 92 & 92 & 92 & 92 & 92 & 90 \\
\hline 87 & 94 & 94 & 94 & 94 & 94 & 93 & 93 & 93 & 93 & 93 & 91 \\
\hline 88 & 95 & 95 & 95 & 95 & 95 & 94 & 94 & 94 & 94 & 94 & 92 \\
\hline- & 96 & 96 & 96 & 96 & 96 & 95 & 95 & 95 & 95 & 95 & 93 \\
\hline 89 & 97 & 97 & 97 & 97 & 97 & 96 & 96 & 96 & 96 & 96 & 94 \\
\hline 90 & 98 & 98 & 98 & 98 & 98 & 242 & 242 & 242 & 242 & 242 & 234 \\
\hline 91 & 99 & 99 & 99 & 99 & 99 & 243 & 243 & 243 & 243 & 243 & 235 \\
\hline 92 & 100 & 100 & 100 & 100 & 100 & 139 & 139 & 139 & 139 & 139 & 134 \\
\hline 93 & 101 & 101 & 101 & 101 & 101 & 140 & 140 & 140 & 140 & 140 & 135 \\
\hline 94 & 102 & 102 & 102 & 102 & 102 & 141 & 141 & 141 & 141 & 141 & 136 \\
\hline 95 & 103 & 103 & 103 & 103 & 103 & 142 & 142 & 142 & 142 & 142 & 137 \\
\hline 96 & 104 & 104 & 104 & 104 & 104 & 143 & 143 & 143 & 143 & 143 & 138 \\
\hline 97 & 105 & 105 & 105 & 105 & 105 & 144 & 144 & 144 & 144 & 144 & 139 \\
\hline 98 & 106 & 106 & 106 & 106 & 106 & 145 & 145 & 145 & 145 & 145 & 140 \\
\hline 99 & 107 & 107 & 107 & 107 & 107 & 146 & 146 & 146 & 146 & 146 & 141 \\
\hline 100 & 108 & 108 & 108 & 108 & 108 & 147 & 147 & 147 & 147 & 147 & 142 \\
\hline 101 & 109 & 109 & 109 & 109 & 109 & 39 & 39 & 39 & 39 & 39 & 38 \\
\hline 102 & 110 & 110 & 110 & 110 & 110 & 244 & 244 & 244 & 244 & 244 & 236 \\
\hline 125 & 111 & 111 & 111 & 111 & 111 & 245 & 245 & 245 & 245 & 245 & 237 \\
\hline 103 & 112 & 112 & 112 & 112 & 112 & 161 & 161 & 161 & 161 & 161 & 156 \\
\hline 104 & 113 & 113 & 113 & 113 & 113 & 246 & 246 & 246 & 246 & 246 & 238 \\
\hline 105 & 114 & 114 & 114 & 114 & 114 & 25 & 25 & 25 & 25 & 25 & 24 \\
\hline 106 & 115 & 115 & 115 & 115 & 115 & 100 & 100 & 100 & 100 & 100 & 98 \\
\hline 107 & 116 & 116 & 116 & 116 & 116 & 3 & 3 & 3 & 3 & 3 & 3 \\
\hline 108 & 117 & 117 & 117 & 117 & 117 & 99 & 99 & 99 & 99 & 99 & 97 \\
\hline 109 & 118 & 118 & 118 & 118 & 118 & 130 & 130 & 130 & 130 & 130 & 125 \\
\hline 110 & 119 & 119 & 119 & 119 & 119 & 247 & 247 & 247 & 247 & 247 & 239 \\
\hline 111 & 120 & 120 & 120 & 120 & 120 & 248 & 248 & 248 & 248 & 248 & 240 \\
\hline 112 & 121 & 121 & 121 & 121 & 121 & 249 & 249 & 249 & 249 & 249 & 241 \\
\hline 113 & 122 & 122 & 122 & 122 & 122 & 169 & 169 & 169 & 169 & 169 & 162 \\
\hline
\end{tabular}




\begin{tabular}{|c|c|c|c|c|c|c|c|c|c|c|c|}
\hline 114 & 123 & 123 & 123 & 123 & 123 & 170 & 170 & 170 & 170 & 170 & 163 \\
\hline- & 124 & 124 & 124 & 124 & 124 & 4 & 4 & 4 & 4 & 4 & 4 \\
\hline 115 & 125 & 125 & 125 & 125 & 125 & 5 & 5 & 5 & 5 & 5 & 5 \\
\hline 116 & 126 & 126 & 126 & 126 & 126 & 6 & 6 & 6 & 6 & 6 & 6 \\
\hline 117 & 127 & 127 & 127 & 127 & 127 & 40 & 40 & 40 & 40 & 40 & 39 \\
\hline 118 & 128 & 128 & 128 & 128 & 128 & 41 & 41 & 41 & 41 & 41 & 40 \\
\hline 119 & 129 & 129 & 129 & 129 & 129 & 101 & 101 & 101 & 101 & 101 & 99 \\
\hline 120 & 130 & 130 & 130 & 130 & 130 & 102 & 102 & 102 & 102 & 102 & 100 \\
\hline 121 & 131 & 131 & 131 & 131 & 131 & 103 & 103 & 103 & 103 & 103 & - \\
\hline 122 & 132 & 132 & 132 & 132 & 132 & 42 & 42 & 42 & 42 & 42 & 41 \\
\hline 123 & 133 & 133 & 133 & 133 & 133 & 7 & 7 & 7 & 7 & 7 & 7 \\
\hline 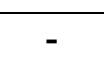 & 134 & 134 & 134 & 134 & 134 & 8 & 8 & 8 & 8 & 8 & 8 \\
\hline 124 & 135 & 135 & 135 & 135 & 135 & 171 & 171 & 171 & 171 & 171 & 164 \\
\hline 126 & 136 & 136 & 136 & 136 & 136 & 172 & 172 & 172 & 172 & 172 & 165 \\
\hline 127 & 137 & 137 & 137 & 137 & 137 & 173 & 173 & 173 & 173 & 173 & 166 \\
\hline 128 & 138 & 138 & 138 & 138 & 138 & 174 & 174 & 174 & 174 & 174 & 167 \\
\hline 129 & 139 & 139 & 139 & 139 & 139 & 250 & 250 & 250 & 250 & 250 & 242 \\
\hline 130 & 140 & 140 & 140 & 140 & 140 & 175 & 175 & 175 & 175 & 175 & 168 \\
\hline 131 & 141 & 141 & 141 & 141 & 141 & 176 & 176 & 176 & 176 & 176 & 169 \\
\hline 132 & 142 & 142 & 142 & 142 & 142 & 177 & 177 & 177 & 177 & 177 & 170 \\
\hline 133 & 143 & 143 & 143 & 143 & 143 & 178 & 178 & 178 & 178 & 178 & 171 \\
\hline 134 & 144 & 144 & 144 & 144 & 144 & 179 & 179 & 179 & 179 & 179 & 172 \\
\hline 135 & 145 & 145 & 145 & 145 & 145 & 75 & 75 & 75 & 75 & 75 & 73 \\
\hline 136 & 146 & 146 & 146 & 146 & 146 & 76 & 76 & 76 & 76 & 76 & 74 \\
\hline 137 & 147 & 147 & 147 & 147 & 147 & 77 & 77 & 77 & 77 & 77 & 75 \\
\hline 138 & 148 & 148 & 148 & 148 & 148 & 180 & 180 & 180 & 180 & 180 & 173 \\
\hline 139 & 149 & 149 & 149 & 149 & 149 & 251 & 251 & 251 & 251 & 251 & - \\
\hline 140 & 150 & 150 & 150 & 150 & 150 & 104 & 104 & 104 & 104 & 104 & 101 \\
\hline 141 & 151 & 151 & 151 & 151 & 151 & 181 & 181 & 181 & 181 & 181 & 174 \\
\hline 142 & 152 & 152 & 152 & 152 & 152 & 182 & 182 & 182 & 182 & 182 & 175 \\
\hline 143 & 153 & 153 & 153 & 153 & 153 & 183 & 183 & 183 & 183 & 183 & 176 \\
\hline 144 & 154 & 154 & 154 & 154 & 154 & 184 & 184 & 184 & 184 & 184 & 177 \\
\hline
\end{tabular}




\begin{tabular}{|c|c|c|c|c|c|c|c|c|c|c|c|}
\hline 145 & 155 & 155 & 155 & 155 & 155 & 185 & 185 & 185 & 185 & 185 & 178 \\
\hline 146 & 156 & 156 & 156 & 156 & 156 & 122 & 122 & 122 & 122 & 122 & 118 \\
\hline - & 157 & 157 & 157 & 157 & 157 & 123 & 123 & 123 & 123 & 123 & 119 \\
\hline 147 & 157 & 157 & 157 & 158 & 157 & 124 & 124 & 124 & 124 & 124 & 120 \\
\hline- & 159 & 159 & 159 & 159 & 159 & 125 & 125 & 125 & 125 & 125 & 121 \\
\hline- & 160 & 160 & 160 & 160 & 160 & 126 & 126 & 126 & 126 & 126 & 122 \\
\hline 148 & 161 & 161 & 161 & 161 & 161 & 127 & 127 & 127 & 127 & 127 & 123 \\
\hline 149 & 162 & 162 & 162 & 162 & 162 & 252 & 252 & 252 & 252 & 252 & 243 \\
\hline 150 & 163 & 163 & 163 & 163 & 163 & 186 & 186 & 186 & 186 & 186 & 179 \\
\hline 151 & 164 & 164 & 164 & 164 & 164 & 187 & 187 & 187 & 187 & 187 & 180 \\
\hline 152 & 165 & 165 & 165 & 165 & 165 & 188 & 188 & 188 & 188 & 188 & 181 \\
\hline 153 & 166 & 166 & 166 & 166 & 166 & 189 & 189 & 189 & 189 & 189 & 182 \\
\hline 154 & 167 & 167 & 167 & 167 & 167 & 190 & 190 & 190 & 190 & 190 & 183 \\
\hline - & 168 & 168 & 168 & 168 & 168 & 9 & 9 & 9 & 9 & 9 & 9 \\
\hline- & 169 & 169 & 169 & 169 & 169 & 10 & 10 & 10 & 10 & 10 & 10 \\
\hline- & 170 & 170 & 170 & 170 & 170 & 11 & 11 & 11 & 11 & 11 & 11 \\
\hline- & 171 & 171 & 171 & 171 & 171 & 12 & 12 & 12 & 12 & 12 & 12 \\
\hline- & 172 & 172 & 172 & 172 & 172 & 43 & 43 & 43 & 43 & 43 & - \\
\hline- & 173 & 173 & 173 & 173 & 173 & 191 & 191 & 191 & 191 & 191 & 184 \\
\hline- & 174 & 174 & 174 & 174 & 174 & 192 & 192 & 192 & 192 & 192 & 185 \\
\hline- & 175 & 175 & 175 & 175 & 175 & 193 & 193 & 193 & 193 & 193 & 186 \\
\hline- & 176 & 176 & 176 & 176 & 176 & 194 & 194 & 194 & 194 & 194 & 187 \\
\hline- & 177 & 177 & 177 & 177 & 177 & 128 & 128 & 128 & 128 & 128 & - \\
\hline- & 178 & 178 & 178 & 178 & 178 & 148 & 148 & 148 & 148 & 148 & 143 \\
\hline- & 179 & 179 & 179 & 179 & 179 & 149 & 149 & 149 & 149 & 149 & 144 \\
\hline- & 180 & 180 & 180 & 180 & 180 & 129 & 129 & 129 & 129 & 129 & 124 \\
\hline- & 181 & 181 & 181 & 181 & 181 & 44 & 44 & 44 & 44 & 44 & 42 \\
\hline- & 182 & 182 & 182 & 182 & 182 & 45 & 45 & 45 & 45 & 45 & 43 \\
\hline- & 183 & 183 & 183 & 183 & 183 & 195 & 195 & 195 & 195 & 195 & 188 \\
\hline- & 184 & 184 & 184 & 184 & 184 & 196 & 196 & 196 & 196 & 196 & 189 \\
\hline- & 185 & 185 & 185 & 185 & 185 & 197 & 197 & 197 & 197 & 197 & 190 \\
\hline- & 186 & 186 & 186 & 186 & 186 & 198 & 198 & 198 & 198 & 198 & 191 \\
\hline
\end{tabular}




\begin{tabular}{|c|c|c|c|c|c|c|c|c|c|c|c|}
\hline - & 187 & 187 & 187 & 187 & 187 & 199 & 199 & 199 & 199 & 199 & 192 \\
\hline - & 188 & 188 & 188 & 188 & 188 & 200 & 200 & 200 & 200 & 200 & 193 \\
\hline- & 189 & 189 & 189 & 189 & 189 & 201 & 201 & 201 & 201 & 201 & 194 \\
\hline- & 190 & 190 & 190 & 190 & 190 & 13 & 13 & 13 & 13 & 13 & 13 \\
\hline - & - & 191 & 191 & 191 & 191 & 14 & 14 & 14 & 14 & 14 & 14 \\
\hline - & - & 192 & 192 & 192 & 192 & 15 & 15 & 15 & 15 & 15 & 15 \\
\hline- & 191 & 193 & 193 & 193 & 193 & 16 & 16 & 16 & 16 & 16 & 16 \\
\hline- & 192 & 194 & 194 & 194 & 194 & 17 & 17 & 17 & 17 & 17 & 17 \\
\hline - & 193 & 195 & 195 & 195 & 195 & 253 & 253 & 253 & 253 & 253 & 244 \\
\hline - & 194 & 196 & 196 & 196 & 196 & 254 & 254 & 254 & 254 & 254 & 245 \\
\hline- & 195 & 197 & 197 & 197 & 197 & 255 & 255 & 255 & 255 & 255 & 246 \\
\hline - & 196 & 198 & 198 & 198 & 198 & 202 & 202 & 202 & 202 & 202 & 195 \\
\hline - & 197 & 199 & 199 & 199 & 199 & 203 & 203 & 203 & 203 & 203 & - \\
\hline- & 198 & 200 & 200 & 200 & 200 & 204 & 204 & 204 & 204 & 204 & 196 \\
\hline- & 199 & 201 & 201 & 201 & 201 & 205 & 205 & 205 & 205 & 205 & 197 \\
\hline - & 200 & 202 & 202 & 202 & 202 & 206 & 206 & 206 & 206 & 206 & 198 \\
\hline - & 201 & 203 & 203 & 203 & 203 & 207 & 207 & 207 & 207 & 207 & 199 \\
\hline - & 202 & 204 & 204 & 204 & 204 & 208 & 208 & 208 & 208 & 208 & 200 \\
\hline - & 203 & 205 & 205 & 205 & 205 & 209 & 209 & 209 & 209 & 209 & 201 \\
\hline - & 204 & 206 & 206 & 206 & 206 & 210 & 210 & 210 & 210 & 210 & 202 \\
\hline - & 205 & 207 & 207 & 207 & 207 & 211 & 211 & 211 & 211 & 211 & 203 \\
\hline - & 206 & 208 & 208 & 208 & 208 & 18 & 18 & 18 & 18 & 18 & 18 \\
\hline - & 207 & 209 & 209 & 209 & 209 & 212 & 212 & 212 & 212 & 212 & 204 \\
\hline - & 208 & 210 & 210 & 210 & 210 & 213 & 213 & 213 & 213 & 213 & 205 \\
\hline - & 209 & 211 & 211 & 211 & 211 & 214 & 214 & 214 & 214 & 214 & 206 \\
\hline - & 210 & 212 & 212 & 212 & 212 & 215 & 215 & 215 & 215 & 215 & 207 \\
\hline - & 211 & 213 & 213 & 213 & 213 & 216 & 216 & 216 & 216 & 216 & 208 \\
\hline - & 212 & 214 & 214 & 214 & 214 & 217 & 217 & 217 & 217 & 217 & 209 \\
\hline - & 213 & 215 & 215 & 215 & 215 & 218 & 218 & 218 & 218 & 218 & 210 \\
\hline - & 214 & 216 & 216 & 216 & 216 & 219 & 219 & 219 & 219 & 219 & 211 \\
\hline - & 215 & 217 & 217 & 217 & 217 & 220 & 220 & 220 & 220 & 220 & 212 \\
\hline - & 216 & 218 & 218 & 218 & 218 & 221 & 221 & 221 & 221 & 221 & 213 \\
\hline
\end{tabular}




\begin{tabular}{|c|c|c|c|c|c|c|c|c|c|c|c|}
\hline- & 217 & 219 & 219 & 219 & 219 & 222 & 222 & 222 & 222 & 222 & 214 \\
\hline- & 218 & 220 & 220 & 220 & 220 & 223 & 223 & 223 & 223 & 223 & 215 \\
\hline- & 219 & 221 & 221 & 221 & 221 & 224 & 224 & 224 & 224 & 224 & 216 \\
\hline - & 220 & 222 & 222 & 222 & 222 & 105 & 105 & 105 & 105 & 105 & 102 \\
\hline- & 221 & 223 & 223 & 223 & 223 & 106 & 106 & 106 & 106 & 106 & 103 \\
\hline - & 222 & 224 & 224 & 224 & 224 & 107 & 107 & 107 & 107 & 107 & 104 \\
\hline- & 223 & 225 & 225 & 225 & 225 & 78 & 78 & 78 & 78 & 78 & 76 \\
\hline - & 224 & 226 & 226 & 226 & 226 & 79 & 79 & 79 & 79 & 79 & 77 \\
\hline - & 225 & 227 & 227 & 227 & 227 & 80 & 80 & 80 & 80 & 80 & 78 \\
\hline - & 226 & 228 & 228 & 228 & 228 & 81 & 81 & 81 & 81 & 81 & 79 \\
\hline- & 227 & 229 & 229 & 229 & 229 & 82 & 82 & 82 & 82 & 82 & 80 \\
\hline- & 228 & 230 & 230 & 230 & 230 & 83 & 83 & 83 & 83 & 83 & 81 \\
\hline - & 229 & 231 & 231 & 231 & 231 & 225 & 225 & 225 & 225 & 225 & 217 \\
\hline- & 230 & 232 & 232 & 232 & 232 & 226 & 226 & 226 & 226 & 226 & 218 \\
\hline - & 231 & 233 & 233 & 233 & 233 & 227 & 227 & 227 & 227 & 227 & 219 \\
\hline - & 232 & 234 & 234 & 234 & 234 & 228 & 228 & 228 & 228 & 228 & 220 \\
\hline- & 233 & 235 & 235 & 235 & 235 & 229 & 229 & 229 & 229 & 229 & 221 \\
\hline- & 234 & 236 & 236 & 236 & 236 & 230 & 230 & 230 & 230 & 230 & 222 \\
\hline - & 235 & 237 & 237 & 237 & 237 & 231 & 231 & 231 & 231 & 231 & 223 \\
\hline- & 236 & 238 & 238 & 238 & 238 & 232 & 232 & 232 & 232 & 232 & 224 \\
\hline- & 237 & 239 & 239 & 239 & 239 & 233 & 233 & 233 & 233 & 233 & 225 \\
\hline - & 238 & 240 & 240 & 240 & 240 & 234 & 234 & 234 & 234 & 234 & 226 \\
\hline- & 239 & 241 & 241 & 241 & 241 & 235 & 235 & 235 & 235 & 235 & 227 \\
\hline- & 240 & 242 & 242 & 242 & 242 & 236 & 236 & 236 & 236 & 236 & 228 \\
\hline- & 241 & 243 & 243 & 243 & 243 & 237 & 237 & 237 & 237 & 237 & 229 \\
\hline- & 242 & 244 & 244 & 244 & 244 & 238 & 238 & 238 & 238 & 238 & 230 \\
\hline- & 243 & 245 & 245 & 245 & 245 & 239 & 239 & 239 & 239 & 239 & 231 \\
\hline- & 244 & 246 & 246 & 246 & 246 & 240 & 240 & 240 & 240 & 240 & 232 \\
\hline- & 245 & 247 & 247 & 247 & 247 & 241 & 241 & 241 & 241 & 241 & 233 \\
\hline - & - & 248 & 248 & 248 & 248 & 131 & 131 & 131 & 131 & 131 & 126 \\
\hline- & - & 249 & 249 & 249 & 249 & 132 & 132 & 132 & 132 & 132 & 127 \\
\hline - & - & 250 & 250 & 250 & 250 & 133 & 133 & 133 & 133 & 133 & 128 \\
\hline
\end{tabular}




\begin{tabular}{|c|c|c|c|c|c|c|c|c|c|c|c|c|}
\hline & - & - & 251 & 251 & $\mathbf{2 5 1}$ & 251 & 134 & 134 & 134 & 134 & 134 & 129 \\
\cline { 2 - 11 } & - & - & 252 & 252 & $\mathbf{2 5 2}$ & 252 & 135 & 135 & 135 & 135 & 135 & 130 \\
\cline { 2 - 11 }$y$ & - & - & 253 & 253 & $\mathbf{2 5 3}$ & 253 & 136 & 136 & 136 & 136 & 136 & 131 \\
\cline { 2 - 11 } & - & - & 254 & 254 & $\mathbf{2 5 4}$ & 254 & 137 & 137 & 137 & 137 & 137 & 132 \\
\cline { 2 - 11 } & - & - & 255 & 255 & $\mathbf{2 5 5}$ & 255 & 138 & 138 & 138 & 138 & 138 & 133 \\
\cline { 2 - 11 } & - & - & - & 256 & $\mathbf{2 5 6}$ & 256 & 19 & 19 & 19 & 19 & 19 & - \\
\hline Total & 154 & 245 & 255 & 256 & $\mathbf{2 5 6}$ & 256 & 255 & 255 & 255 & 255 & 255 & 246 \\
\hline
\end{tabular}

